University of Massachusetts Amherst

ScholarWorks@UMass Amherst

Doctoral Dissertations 1896 - February 2014

$1-1-1981$

\title{
The Soviet perception of detente : an analysis of the ideological continuity of the policy of peaceful coexistence from Lenin to Brezhnev.
}

Stephen Robert Willand

University of Massachusetts Amherst

Follow this and additional works at: https://scholarworks.umass.edu/dissertations_1

\section{Recommended Citation}

Willand, Stephen Robert, "The Soviet perception of detente : an analysis of the ideological continuity of the policy of peaceful coexistence from Lenin to Brezhnev." (1981). Doctoral Dissertations 1896 - February 2014. 1897.

https://doi.org/10.7275/cgg3-3c33 https://scholarworks.umass.edu/dissertations_1/1897

This Open Access Dissertation is brought to you for free and open access by ScholarWorks@UMass Amherst. It has been accepted for inclusion in Doctoral Dissertations 1896 - February 2014 by an authorized administrator of ScholarWorks@UMass Amherst. For more information, please contact scholarworks@library.umass.edu. 


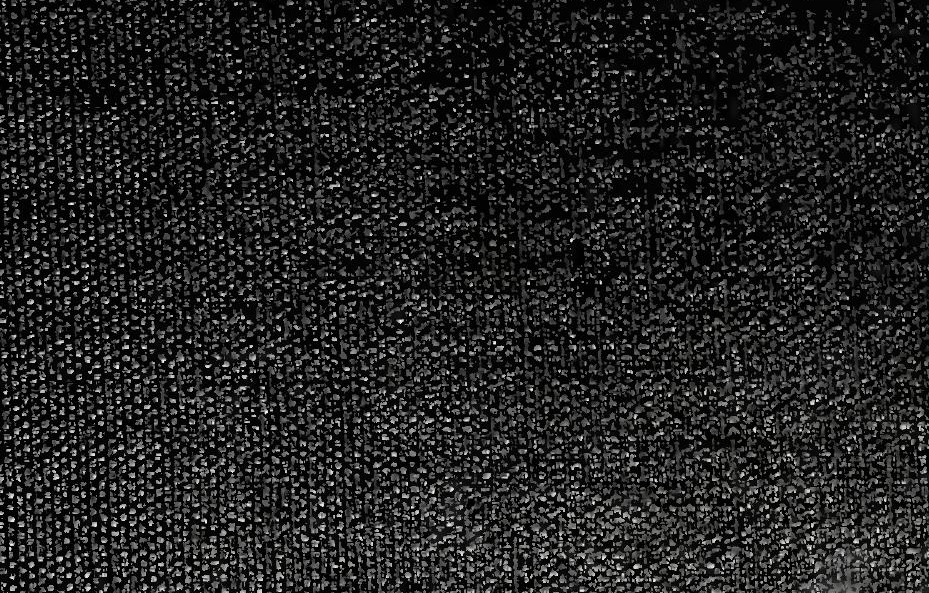

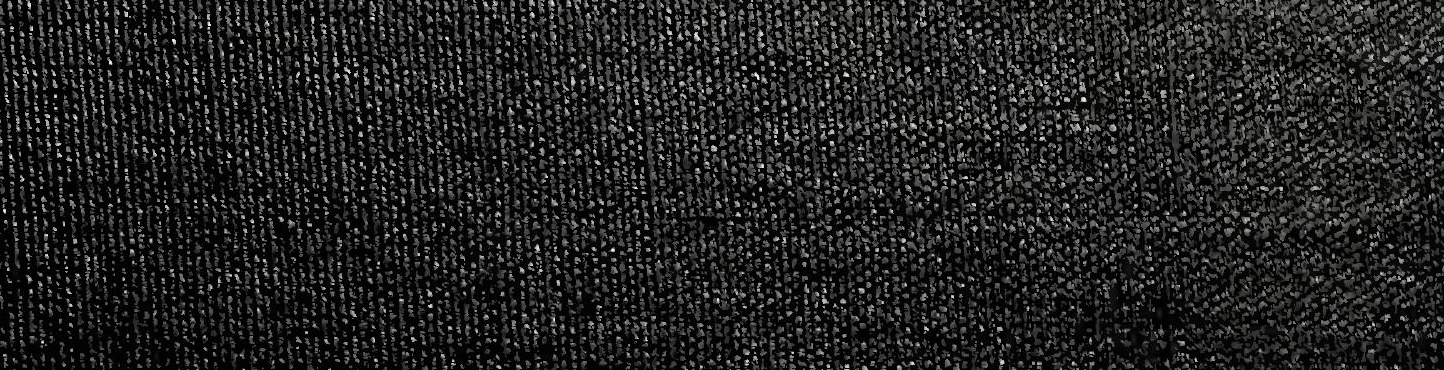

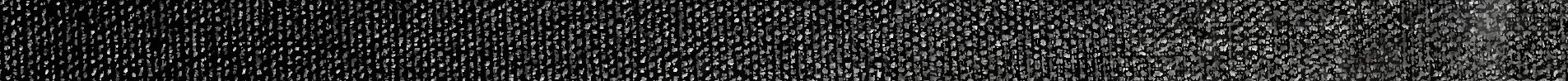

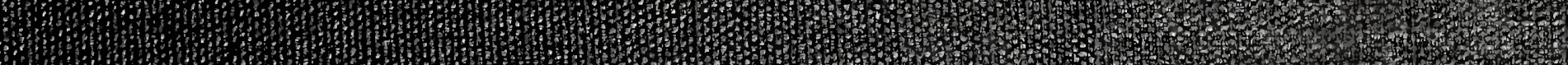

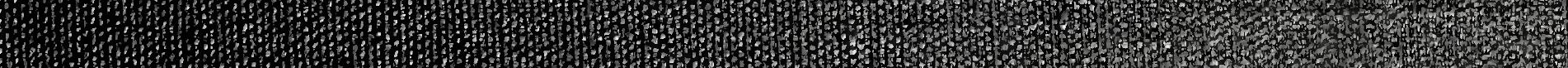


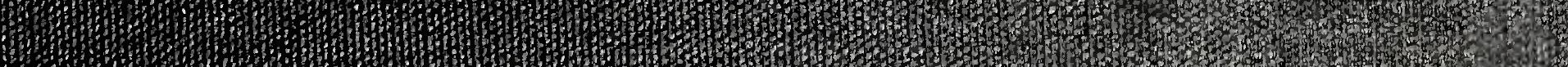

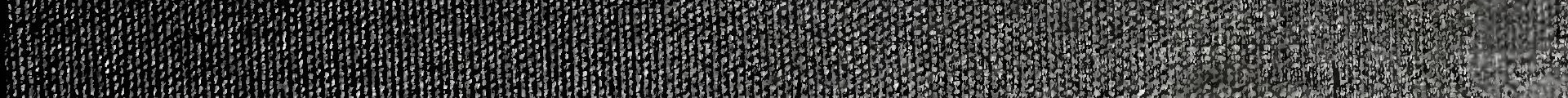

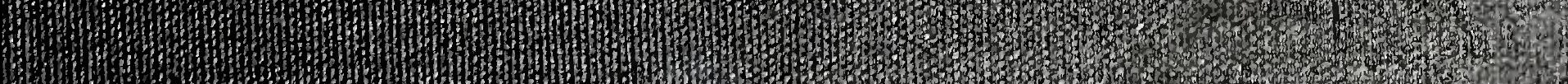

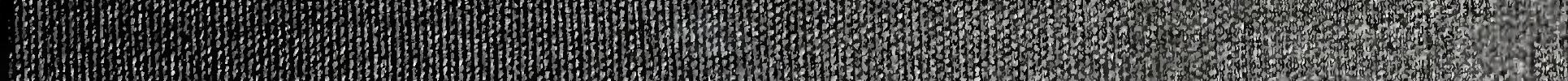


THE SOVIET PERCEPTION OF DETENTE: AN ANALYSIS OF THE IDEOLOGICAL CONTINUITY OF THE POLICY OF PEACEFUL COEXISTENCE FROM LENIN TO BREZHNEV

A Dissertation Presented

By

Stephen Robert Willand

Submitied to the Graduate School of the iniversity of Massachusetts in partial fulfillment of the requirements for the degree of

DOCTOR OF PHILOSOPHY

May 1987

Poitical Science 
Stephen Robert Willand C

A11 Rights Reserved 
THE SOVIET PERCEPTION OF DETENTE: AN ANALYSIS OF THE IDEOLOGICAL CONTINUITY OF THE POLICY OF PEACEFUL COEXISTENCE FROM LENIN TO BREZHNEV

\author{
A Dissertation Presented \\ By \\ Stephen Robert Willand
}

Approved as to style and content by:

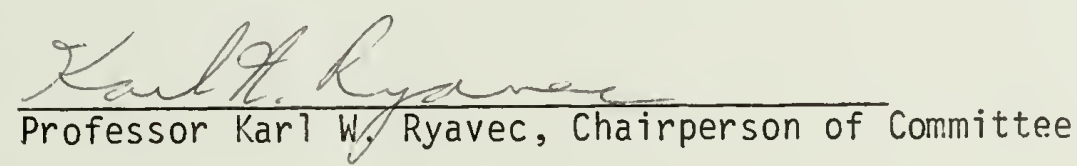

$\frac{\text { Pele hien }}{\text { Professor Peter J. Fliess, Member }}$

$\frac{\text { Nole } t \text { H. Mened }}{\text { Professor Robert H. McNea T, Member }}$

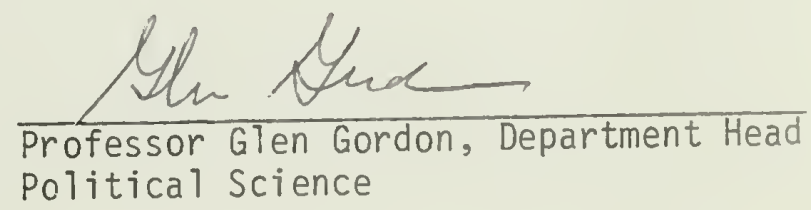




\section{PREFACE}

This dissertation will focus on the subject of Soviet-American detente. It will be demonstrated that the detente policy has caused a good deal of confusion regarding its true meaning both in theory and in practice. After analyzing the most significant schools of thought and different viewpoints in regard to detente, this dissertation will pose three major hypotheses. These hypotheses will address what this writer feels are the most critical aspects of Soviet-American detente and will be assessed throughout the body of this study. This dissertation will place specific emphasis on the Soviet perception of detente and, accordingly, will rely heavily on primary Soviet source documentation.

The first hypothesis will present the belief that detente was a political strategy that was created solely by the U.S.S.R. Furthermore, the Soviet leadership designed detente on the basis of revolutionary Marxist-Leninist ideology; an ideology that serves as an important factor in the conduct of Soviet foreign policy. It will be shown that detente was not a policy that was developed jointly by the United States and the U.S.S.R. Rather, detente was conceived, implemented, and updated by the Soviet Union as a means by which long-term ideological objectives could best be accomplished. The United States, in the Soviet view, never willingly agreed to the conditions of detente that were established by the Soviet Union. The Soviets argue that the United States continualiy opposed the Soviet policy of detente and chose the unfriendly cold war posture as an alternative to the Soviet policy of peace. It was only upon 
reassessing the objective reality of the realignment of world forces in favor of socialism, the growing might of the Soviet Union, and the inherent weakening of and contradictions in the imperialist system that the United States was forced to accept the Soviet policy of detente.

The Soviet Union not only created detente but built the policy on the foundation of Marxist-Leninist ideology. That ideology has done much to define the scope and purpose of Soviet foreign policy in general and detente in particular. Detente was not specifically created as a means by which short-term objectives could be realized or the cause of Soviet national interest served. Rather, historical evidence suggests that detente was designed as the catalyst by which long-term goals could be achieved and the cause of communist ideological objectives addressed. Thus, a presentation will be made in regard to the conflicting schools of thought on the subject of ideology. It will be argued that the central core of detente, a commitment to the ideological goal of the worldwide victory of socialism, has remained in existence throughout the long history of Soviet-American detente.

The second major hypothesis presents the belief that detente was created by V.I. Lenin in 1978, and has remained a constant factor in Soviet foreign policy to this day. Hence, a detailed study of the history of detente will be presented. It will be shown that Lenin designed detente as a means by which to accomplish eight (8) primary objectives. Detente provided the breathing spell, a respite in war, by which Lenin could consolidate internal strength. Detente allowed Lenin to survive as an "oasis" in a sea of capitalist-imperialist adversaries. Detente gave Lenin the means by which he could best prepare for the inevitable East-West military confrontation. Detente provided the means by which Lenin could best forestall the inevitable anti-Soviet alliance of imperialist nations. 
Detente afforded Lenin the opportunity to secure much needed Western, and specifically American, economic assistance. Detente provided the means by which Lenin could exploit the existing contradictions within the imperialist camp. Most importantly, detente provided the fulcrum by which Lenin would achieve his ultimate goal of transforming the world in the socialist order.

It will be shown that Stalin and Khrushchev adhered to and implemented the policy of detente as established by Lenin. While making basic alterations in the policy, both Stalin and Khrushchev maintained the nucleus of detente and formulated Soviet foreign policy on the basis of the detente strategy. It will also be demonstrated that Leonid Brezhnev has maintained both the historical and ideological continuity of detente to this day. Evidence will be presented to support the thesis that the detente of Brezhnev is far more effective than that of any of his predecessors by virtue of the more advantageous and powerful position of the Soviet Union in world affairs. It will be shown that the achievement of strategic parity by the Soviet Union and the augmented ranks of the socialist commonwealth have made detente a very aggressive and highly successful Soviet strategy. It will then be suggested that detente, while maintaining the central objective of a worldwide socialist victory, has been transformed from a defensive ploy to an offensive weapon.

The third major hypothesis will posit the belief that the Soviet policy of detente has posed a serious threat to the interests of the United States. It will be shown that the stated objectives of detente are inimical to the United States and were designed to accrue unilateral advantages to the cause of world socialism. Moreover, the acceptance of detente by the United States, with the inherent limitations imposed by the Soviet Union, has made detente all the more dangerous to American 
interests. It will also be demonstrated that the U.S.S.R. has clearly stated that detente will provide the catalyst for the further dissemination of socialist influence and prestige to the direct detriment of the United States. Detente, in this view, has always provided the best conditions for the proliferation of socialism and the construction of communism.

It will be argued that the Soviet Union has used detente to achieve the ultimate objective of gaining the worldwide victory of socialism. Within this overall strategy the U.S.S.R. has targetted the specific objectives of further augmenting the ranks of non-capitalist nations and of continuing the process of the realignment of world forces in favor of socialism. In order to accomplish this objective the Soviet Union has employed the strategic goal of realigning the Third World, or developing nations, by way of national liberation movements, from the nonsocialist to the socialist camp. Hence, it will be argued that detente imposes unilateral restraints on American action and allows for freedom of action for the U.S.S.R. to pursue its foreign policy objectives. Furthermore, detente does not allow for the preservation of the status quo, the sustainment of the present balance of power, any convergence with the West, the lessening of the inter-camp ideological struggle, or any long-term rapprochement of sorts with the United States. In fact, in the Soviet view, detente guarantees the antithesis of any of these and ensures the shift in the status quo in favor of the "forces of peace," a realignment of the balance of power in favor of world socialism, no convergence with the West, an intensification of the ideological struggle, and an irreversible posture for the policy of capitalist decline and socialist gain. 


\section{ABSTRACT}

THE SOVIET PERCEPTION OF DETENTE: AN ANALYSIS OF THE IDEOLOGICAL CONTINUITY OF THE POLICY OF PEACEFUL COEXISTENCE FROM LENIN TO BREZHNEV

$$
\text { (May, 1981) }
$$

Stephen R. Willand, B.A., College of the Holy Cross

M.A., Center for Advanced International Studies, University

of Miami (Fla.), Ph.D., University of Massachusetts

Directed by: Professor Karl Ryavec

The purpose of this dissertation is to analyze the Soviet perception of detente with specific reference to the conduct of SovietAmerican relations. It is shown that the Soviet understanding of detente differs significantly from that of the United States. Moreover, the Soviet view of detente has been translated from theory to practice and now governs the scope of U.S.-Soviet, and East-West relations.

The first thesis presented is that detente was created by the Soviet Union and was built on the foundation of revolutionary MarxistLeninist ideology. It is demonstrated that detente was never mutually designed by the U.S.S.R. and the United States. Rather, the policy of detente was conceived by the Soviet Union as a means by which to achieve long-term Soviet ideological objectives. The United States, in this view, was forced to accept the Soviet policy of detente by virtue of the objective factors underlying the growing might of the Soviet Union and the alignment of world forces in favor of socialism. Furthermore, this dissertation differs with the "end of ideology" thesis and posits the belief that ideology serves as an important determining factor in the 
formulation of all Soviet foreign policy in general and detente in particular. It is shown that the ideological goal of the worldwide victory of socialism has remained as the nucleus of the Soviet policy of detente.

The second thesis is that detente was created by V.I. Lenin in 1918, and has remained a constant factor in Soviet foreign policy to this day. It is demonstrated that Lenin utilized eight (8) criteria to develop a defensive detente policy aimed at gaining the valuable time necessary to strengthen the Soviet Union for the inevitable EastWest military confrontation. Stalin continued the Leninist detente strategy and greatly improved the position of the U.S.S.R. relative to its chief imperialist adversary. Khrushchev transformed detente from a defensive maneuver to an offensive strategy aimed at effecting incremental changes in the East-West balance of power without the need for inevitable Soviet-American military confrontations. Brezhnev, in achieving military parity, made detente an aggressive strategy that would serve the cause of world socialism to the detriment of the United States.

The third thesis is that detente has posed and will continue to pose serious threats to the interests of the United States. It is shown that detente from the Soviet perspective guarantees an intensification of the East-West ideological struggle, the further decline of American prestige, no convergence with the United States, a deepening of class antagonisms, a repudiation of the status quo, and creates the best conditions for the further growth of socialism and the building of communism. Rather than establishing a rapprochement between the United States and the Soviet Union, detente places unilateral restraints on American action and allows for the active pursuit of Soviet ideological goals. 
Detente is employed by the U.S.S.R. as the best means by which to achieve its final objective - the complete victory of socialism - by its strategic objective of the further alignment of world forces in favor of socialism, and its specific strategy of aligning the developing nations, through anti-imperialist national liberation revolutions, into the pro-Soviet socialist camp. 


\section{TABLE OF CONTENTS}

PREFACE

ABSTRACT

Chapter

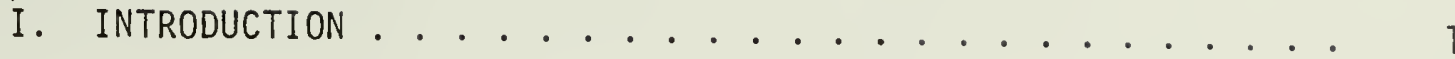

The Setting ................... 1

Hypotheses to be Analyzed . . . . . . . . . . 11

Methodology: The Use of Primary Soviet Source Material . . 14

The Role of Ideology in the Formulation of Soviet

Foreign Policy.............. 16

Review of Pertinent Scholariy Literature . . . . . . 22

Footnotes ................ 2 26

II. THE IMPORTANCE OF DETENTE DURING THE BREZHNEV ERA .... 30

The American Perception of the Importance of Detente . . . 33

The Significance of Detente: The Soviet View. . . . . . . 35

The 1972 "Declaration of Basic Principles" . . . . . . . 37

The Global Nature of Detente . . . . . . . . . . 47

Detente and the Pursuit of Soviet Objectives . . . . . . 50

Footnotes ................... 54

III. THE HISTORICAL CONTEXT OF DETENTE . . . . . . . . 58

Overview .......................... 58

The Long-Term Nature of Detente . . . . . . . . . 59

Soviet Revisionism in Detente ........... 62

The Present Version of Detente . . . . . . . . . 66

The Irreversible Nature of Detente . . . . . . . . 74

Footnotes .............. . . 77

IV. THE LENINIST PERCEPTION AND APPLICATION OF DETENTE . . . . 78

The Historical Setting . . . . . . . . . . 78

Leninist Ideological Revisionism: The Foundation

of Detente . . . . . . . . . . 87

The Early Months of U.S.-Soviet Relations . . . . . 86

1918: The Birth of Detente ........... 91

The eight components of detente........ 107

The Revitalization of Detente: 1920-1921 . . . . 107

Footnotes ................ 133 
V. THE POLICY OF DETENTE AS IMPLEMENTED BY BREZHNEV . . . . . 140

The Stalinist Perception of Detente . . . . . . . 140

Khrushchev's Perception of Detente . . . . . . . . 146

The Brezhnev Adaptation of Detente, 1972-1976 . . . . 151

Detente as a breathing spel1 ........ 165

The Soviet Union as a socialist oasis...... . . 173

Detente as a reaction to American military

superiority . . . . . . . . . . 182

Detente as a preparation for the final East-West war. 189

Detente as a reaction to a potential anti-Soviet

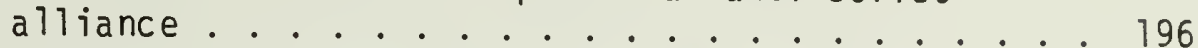

Detente as a means for securing Western economic

assistance . . . . . . . . . . . . 204

Detente as a means to exploit antagonisms within the capitalist-imperialist world . . . . . . . 209

Detente as a means for achieving the final victory

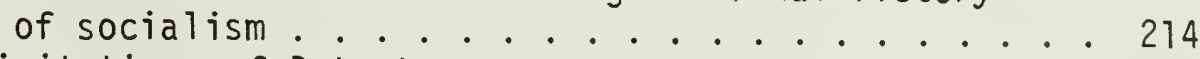

The Limitations of Detente . . . . . . . . . 218

Soviet Objectives Within Detente . . . . . . . . 224

Footnotes .............. . . 237

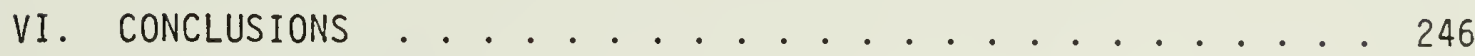

SELECTED BIBLIOGRAPHY . . . . . . . . . . . . 254 


\section{INTRODUCTION}

We are living not merely in a state but in a system of states, and the existence of the Soviet Republic side by side with imperialist states for a long time is unthinkable. One or the other must triumph in the end. And before that end supervenes, a series of frightful collisions between the Soviet Republic and the bourgeois states will be inevitable.

- V.I. Lenin

\section{The Setting}

This dire warning was made by Lenin less than two years after the October revolution of 1917 had swept him and his Bolshevik supporters to the pinnacle of power in Soviet Russia. During this time the fledgling Soviet state was beset with many difficulties that threatened its very existence as a functioning system of government. These problems made it equally difficult for the Soviet government of that time to become a recognized world power conducting a realistic foreign policy with the established nations of the world capitalist system. Yet, while confronted with the socio-economic, political, and military chaos engendered by World War I and the ensuing revolutions, civil strife and civil war, Lenin, some three years before the official formulation of the Soviet Union, had already made it unquestionably clear that Soviet relations with the West would merely be a temporary phenomenon. These relations, according to Lenin, would inevitably terminate with the fatal demise of one of the conflicting systems. Thus, a more ominous prediction was made by Lenin less than one year later: 
As long as capitalism and socialism exist we cannot live in peace. In the end one or the other will triumph - - a funeral dirge will be sung either over the Soviet Republic or over world capitalism. T

It was, therefore, a basic belief of Leninist ideology that a cataclysmic clash between the two conflicting socio-economic systems was unavoidable. In Lenin's view the powers of the world capitalistimperialist structure simply would not submissively acquiesce to the demise of their system. Rather, these nations would employ any and all strategic means at their disposal, including the waging of full-scale war, to forestall the destruction of their dying socio-economic structure. Furthermore, Lenin reasoned that the extinction of the capitalist-imperialist world order was not only historically inevitable but was also predicted by the creation of its antithesis -- the communist controlled socialist government of Soviet Russia.

While Lenin was certain that the Soviet state would inevitably be forced to engage the West in a 1 ife and death struggle, he was equally assured as to the ultimate victor in this unavoidable Armageddon. So as to leave no doubt as to which system of states would be vanquished in this struggle, Lenin further stated:

Despite this (the backwardness of Russia) we are firmly convinced that we are invincible, because mankind will not break down under the imperialist slaughter, but will overcome it. We are beyond imperialist dependence, we raised before the whole world the banner of struggle for the complete overthrow of imperialism.

In a word, we are invincible, because the world proletarian revolution is invincible.?

Such a despairing prognosis for the future of international relations would hardly seem to be conducive to the maintenance of harmonious inter-state relations, especially between those states with differing social systems of the East and West. If one were inclined to 
attach significant emphasis to these apocalyptic warnings of Lenin and, more importantly, to transpose them to the present era of international relations, one might then expect the contemporary international situation to be governed by total animosity between the communist and capitalist world. In fact, one could reasonably argue that Leninist ideology would preclude any future continuation of coexistence between the Soviet state and world capitalism, since the long-term nature of their coexistence from 1917 to today was purely unthinkable for Lenin.

Yet, the contemporary state of international relations, as it exists more than sixty years after the formation of the Soviet state, is far removed from the situation as envisaged by Lenin. To be sure, the Soviet Union and the West, and most notably the United States, must still contend with a series of crises and direct confrontations. Yet no "funeral dirge" has been sung over either system as both the U.S.S.R. and world capitalism have managed to co-habitate the same planet for a reasonably long period of time. What is more, the two global superpowers, one the acknowledged leader of an ever-expanding, albeit polycentric, socialist-camp, and the other the bastion of world capitalism-imperialism, have mutually agreed to embark on a far-reaching course of action aimed at creating a mutual understanding between them and at establishing a viable system of cooperation. Hence, the United States and the Soviet Union since 1972 have negotiated, or are now negotiating, important accords of both a bilateral and multi-lateral nature. For the most part, these agreements have as their stated underlying motivation a movement away from the aforementioned pessimistic view of world politics in the realm of socialist-capitalist relations.

How then does the present course of events correspond to the 
pessimistic world view as espoused by Lenin? Furthermore, how is it that the Soviet state and the nations of the capitalist-imperialist order have managed to exist side by side with each other for such a long period of time -- a thought that was unthinkable in Lenin's mind? Has the present Soviet leadership altered and revised Leninist doctrine so extensively and mellowed so far in their interpretation of the seemingly intransigent communist view of the West to the point of becoming "soft on capitalism" and of finding a permanent modus vivendi with its very ideological antithesis? Have they further, as they have been accused by their most ardent critics within the socialist camp, become revisionists in their own right, forsaking their duty as proletarian internationalists so as to advance the objectives of the Soviet national interest? What have become of the behests of Lenin and, most importantly, his dogmatic assertions that capitalist and socialist nations cannot live in peace for a long period of time? Have these stern ideological tenets become victims of the lack of revolutionary zeal among the faceless party bureaucrats who now hold the mantel of power in the Kremlin? Furthermore, has the present Soviet leadership supplanted Leninist revolutionary ideology with the ideology of East-West convergence and/or indefinite coexistence?

In the minds of many political observers the answers to the questions posited above are in the affirmative. Within the communist world itself, the Soviet Union has not been above reproach in this regard. Leading spokesmen in the People's Republic of China, for example, nave long accused the Soviet Union of "selling out" to the West and of sacrificing the objectives of international proletarianism to the goals of traditional and non-revolutionary Russian national interest. 
While claims and counter-claims of ideological revisionism exist within the communist world, many political observers in the West, albeit for different reasons, arrive at similar conclusions. In this view, the Soviet Union either never strictly adhered to the revolutionary ideology of Lenin or, in the face of a post-industrial thermonuclear world, has realized that ardent Marxist-Leninist revolutionary ideology has outlived its usefulness.

The first theory has its roots in the earliest days of socialistcapitalist relations with the formulation of the Soviet state and the initial Western response. Many Western nations, and most notably the United States, failed to fully understand the revolutionary experiment taking place on Russian soil. The first official American response was somewhat skeptical in nature and looked upon the Bolshevik party and its extremist views on class struggle and revolutions as a short-lived phenomenon that could not exist for a long period of time while basing its existence on the foundations of a militant and fanatical ideology. ${ }^{3}$

The second school of thought, which will be analyzed in greater detail later, theorizes that the pragmatic concerns of a modern nationstate supersede the concerns of political philosophy and form the basis for the present era of international relations characterized by an "end of ideology." 4 In this light, the present Soviet regime has most definitely foresaken the extremist objectives of Leninist ideology with the realization that they are no longer practical nor attainable in the present era of international relations. National interests, traditional power politics, and balance of power concerns, and not Leninist ideology, form the basis of Soviet foreign policy in this regard. 5 Thus, it is quite natural in this view for the present Soviet regime to co-exist with 
the West, at the expense of Leninist revolutionary thought, for it is in the national interest of the Soviet Union to do so. While the Soviet propaganda machine makes repeated assertions to the contrary, they are dismissed, in this view, as ideological rhetoric that in no way forms a basis for the determination of Soviet actions. 6

For whatever reasons, many Western analysts now believe that the behests of Lenin and the dictates of his revolutionary ideology have become lost in a maze of national interests and non-revolutionary concerns that occupy the minds of the policy makers in the Kremlin.

It is not surprising therefore, that few Western political analysts are willing to ascribe a great deal of credibility to the incessant claims by the Brezhnev regime that the class struggle is intensifying, that the ideological antagonisms between the two camps are becoming more acute, and that the present era of international affairs is characterized by the deepest form of ideological struggle between the East and the West. 8 Such assertions are looked upon as mere ideological bombast, a necessary component of the ritual performed by Soviet theoreticians and propagandists. The world view, as espoused by Lenin and reiterated by the Soviet regime to this day, is illogical, in the minds of many, in that it calls for the ultimate defeat of the West, the intensification of the class and ideological struggles, and the primary role of ideology and ideological commitments. Many analysts therefore, find it difficult to believe that the ruling regime of a modern superpower, complete with extensive strategic and conventional military technology and global influence can be iliogical and irrational in regard to its most basic and guiding political philosophy.

During the early Brezhnev years many observers cast a disparaging 
eye on the role of ideology and saw the bureaucratic regime of Brezhnev as providing the catalyst for an era when Soviet-American interests would not be inimical and when a permanent rapprochement between the two nations could be found. It was here that a number of political scientists, journalists, and economists provided theories regarding the eventual harmony that would exist between the two countries. One of the more popular schools of thought in this regard espoused the belief that a convergence of the two opposing systems was inevitable. Arguing that the Soviet Union would most probably not return to capitalism and that the United States would not embark upon communism, it became logical to assume that the two states, in their own best interests, would converge on a middle ground and form a hybrid of the two systems. The Soviet Union, faced with the uselessness of pursuing a militant ideology, would find such a course of action to their benefit since it would, in the words of John Kenneth Galbraith, "dispose of the notion of inevitable conflict based on irreconcilable difference." 9 Yet, the Brezhnev Doctrine, the invasion of Czechoslovakia, and the stigma of "neo-Stalinism" attached to the Brezhnev regime re-emphasized the fact that the Soviet leadership was not interested in any permanent ideological coexistence or convergence of the two ideologies.

In the early 1970's, however, there was new evidence of a reconciliation between the U.S.S.R. and the United States; a reconciliation that culminated in 1972 with the visit of an American president to Moscow. When Richard Nixon and Leonid Brezhnev concluded their agreements and, most importantly, signed the "Declaration of Basic Principles," a new era of Soviet-American relations was proclaimed. Concurrently, many observers saw the long-anticipated reconciliation between the two nations, the 
cessation of ideological polemics between them, and the beginning of a non-ideological age of harmony and mutual interests in the conduct of Soviet-American relations. The catalyst for the rapprochement would be the policy of detente, a policy that would, it was claimed, bring to a halt foreign policies that were based on the belief that irreconcilable ideologies must exist, that each side must attempt to destroy the other, and that the differences between the two nations precluded the attainment of a permanent coexistence.

Detente, in the minds of many, would succeed where so many other theories and policies had failed. Detente would establish the "rules of the game" whereby each party agreed to play within certain limits and, always, avoiding a direct confrontation with the other. Detente would eliminate any aspirations of global hegemony on the part of either country, establish clearly defined spheres of influence, and would emphasize mutual cooperation between the U.S.S.R. and the United States. Most importantly, as we were told incessantly by the American architects of the detente policy, detente would eliminate the possibility of a thermonuclear confrontation between the two global superpowers; a confrontation that would threaten the very existence of mankind.

The policy of detente, in this writer's view, cannot be expected to achieve any of the aforementioned objectives. If the stated objectives of the detente policy are those of modifying the Soviet adherence to ideological dogma, and compliance with the long-term goals of Leninist ideology, then it has been and will continue to be ineffective. If its objectives are those of codifying rules, establishing spheres of influence, and setting limits on acceptable action by the Soviet Union, then it will be equally ineffective. Detente, in this writer's view, will not 
provide a viable deterrent to the pursuit of Soviet objectives that are inimical to the best interests of the United States. In fact, continued acquiesence on the part of the American government to the policy of detente, as witnessed from 1972 to the present, may well serve to enhance the prospects of continued unilateral Soviet advantages in the realm of international affairs.

In an attempt to support these claims, this dissertation will subject certain significant areas of the policy of detente to a fairly detailed scrutiny. Throughout this analysis heavy emphasis will be given to the Soviet perception of detente. It is clearly the goal of this dissertation to analyze Soviet motives and rationales and to reach some logical conclusions in regard to Soviet thought as it pertains to the detente strategy. It will be important, of course, to examine the American perception and understanding of detente quite closely as we11; yet, this analysis will be less intensive than the study of the Soviet viewpoint.

This dissertation will also provide an historical analysis of the detente policy from Lenin to Brezhnev. The major focus of the detente strategy in the Brezhnev era will center on the period from 1972 to 1976. It was during this time span that the Soviet leadership accorded the detente strategy the highest level of prestige and when the American government pursued the detente line with the most ardent vigor.

With the innauguration of President Carter in 1977 the American perception and pursuance of the policy of detente underwent basic alterations that at first were very subtle, and most recently have been somewhat dramatic. The initial emphasis on international human rights, and a less enthusiastic American pursuit of detente led many observers to conclude that detente as a viable tool in the management of 
Soviet-American affairs might quietly wither away as each side reverted to a Cold War relationship. Recent events have added further fuel to the fires of those writing the obituaries for detente. The faltering SALT negotiations, the crisis in Iran, the Soviet invasion of Afghanistan, and the ensuing American boycott of the Oiympic Games in Moscow have all contributed to the belief that detente had, in fact, been eliminated from the list of foreign policy objectives of both the U.S.S.R. and the United States. The resignation of Secretary of State Cyrus Vance, an acknowledged moderate in regard to the Soviet Union, and the apparent victory of the "hardliners" epitomized by National Security Advisor Zbigniew Brzezinski have added further vigor to the death of detente philosophy. The innauguration of President Reagan has, of course, also done much to inspire those who would write the final epitaph of detente.

It is this writer's belief that such a view is erroneous in that it acknowledges only one perception of detente, the American, to the exclusion of the Soviet understanding of the policy. If detente did indeed die in 1979 or 1980 it did so only from the perspective of the American government and Western political commentators. The view from the Kremlin is vastly different. In Moscow's view, detente was never meant to exclude any of the animosities, conflicts, or crises in United States-Soviet relations that now cause such concern in the United States. On the contrary, detente as the Soviet Union has consistently informed us, allows for the intensification of the worldwide class struggle and the strengthening of the ideological conflict between the world's two great superpowers. As Leonid Brezhnev stated shortly after the departure from Moscow of Richard Nixon: 
Striving for the confirmation of the principle of peaceful coexistence, we recognize that successes in this important matter in no way signify the possibility of weakening the ideological struggle. On the contrary, it is necessary to be prepared that this struggle will intensify, will become a still sharper form of the antagonism between the two social systems. And we do not have any doubts about the outcome of this struggle, for the truth of history, the objective laws of social development are on our side. 10

The Soviet Union has claimed that there is little, if any, difference in their perception of the policy of detente during the entire Carter administration and the period from 1972 to 1976 . Nothing has changed in the minds of the Kremlin leaders in regard to detente's goals and objectives, its ideological content, or the acceptable foreign policy actions that it permits. What has changed is the American willingness to fully accept the Soviet doctrine of detente and to make such an acceptance the primary goal of American foreign policy.

\section{Hypotheses To Be Analyzed}

In this writer's view, the policy of detente, as a process that governs the relations between the world's two most powerful nations, represents an important, if not the most important, aspect of international relations. Yet, at the same time, detente has been and will continue to be a phenomenon that causes no small amount of confusion and uncertainty. These areas of confusion will be addressed in the form of three basic hypotheses to be presented here and analyzed in detail throughout the dissertation.

The first hypothesis to be posited is that detente is a political strategy that was designed and conceived by the U.S.S.R., that has its theoretical foundation in revolutionary Marxist-Leninist ideology, and that is governed to a large degree by the dictates of Soviet ideology. 
It will be shown that detente was never a mutually developed process by the nations of the East and West in general, or the Soviet Union and United States in particular. Rather, as will be demonstrated, detente was born of necessity to a Soviet leadership that, while attempting to prepare itself for an inevitable confrontation with the West, desperately groped for a process that would defer this confrontation to a more advantageous time. The detente scheme was written by the Soviet Union and fostered by a realistic assessment by the Soviet ruling hierarchy that they faced an insurmountable disadvantage in military and industrial technology vis-a-vis the West. It will be shown that detente as a policy, and a Soviet strategy for action, was designed by its creators as a means by which long-term Soviet goals and objectives could be realized.

Furthermore, the ideological continuity of the detente process from its original Leninist design to the present Soviet interpretation will be given special emphasis. It will be argued that the most basic component of detente is the goal of the ultimate defeat of the world capitalist-imperialist structure, which was fashioned by the tenets of Marxist-Leninist ideology.

The second major hypothesis posits the belief that the present Soviet-American detente structure is the latest variation and maturation of a policy that was originally developed in 1918 by Lenin. Confronted with a host of domestic difficulties, Lenin formed the strategy of detente as a means by which to both postpone a direct clash with the west and strengthen his country for the eventual pursuit of long-term and global foreign policy objectives. There is evidence that suggests that detente, while adapting to the changing environment of international relations, has maintained the essential core of the Leninist detente to this day. 
The third hypothesis is that the Soviet perception and application of the detente strategy has posed and will continue to pose a serious threat to American interests and may accrue continued unilateral advantages to the Soviet cause. This thesis is directly related to the first two hypotheses. If the process of detente was designed by the Soviet Union, and if the nucleus of its development has been a hostile ideology with stated objectives that are antithetical to those of the United States, then it is logical to assume that the process itself poses a threat to the United States. The Soviet perception of detente is replete with assertions that the ideological struggle will intensify, the class antagonisms with the West will become more acute, and that detente was developed as a result of Western weakness and futility, as well as a drastic change in the correlation of world forces in favor of the communist world. Furthermore, the Soviets have told us that detente is a strategy for struggle that is aimed at the ultimate defeat of the West. As such, it implies no convergence with the West, utilizes economic and scientific competition, condones Soviet-backed "wars of national liberation," allows for the expansion of communist influence, permits "violent paths to power," is not applicable to other socialist states, realizes a persistent danger of inter-camp wars, condones continued Soviet military buildup, and calls for new and strengthened roles for the Soviet military forces. This theoretical perception of detente by the Soviet Union has been directly translated into practice. The Soviet support of the MPLA forces in Angola, economic assistance to the new Iranian government, Soviet activity in Ethiopia, the invasion of Afghanistan, among other actions, were all undertaken within the framework of the Soviet perception of detente. In short, detente, in the Soviet view, sets no limits on hostile Soviet actions, and, 
in many ways, allows for their more active pursuit. American policymakers have expressed the belief that short-term or regional objectives and victories by the U.S.S.R. do not warrant the elimination of the detente policy and, it is supposed, the consequent renewal of the threat of thermonuclear war. As such, the process of detente has hampered American activities in the realm of foreign policy and possesses the potential to continue to do so in the future.

\section{Methodology: The Use of Primary Soviet Source Material}

The serious student attempting to analyze Soviet politics and predict Soviet behavior has been consistently beset with a host of difficulties not usually encountered by political scientists and area specialists who are not concerned with the political machinations of the Kremlin regime. Much of this difficulty, of course, stems from the very nature of the Soviet political system which has all too often excluded or rendered useless the traditional and accepted methods of analysis and observation employed in investigative scholarship in other areas. 11 It has been claimed that this lack of conventional research techniques in regard to the Soviet Union has led to a good deal of Western ignoranze of the U.S.S.R. ${ }^{12}$ ignorance that may well have led to serious and costly miscalculations regarding Soviet motives, especially in the immediate post-World War II years. 13

It was partially in response to the costly lessons learned in dealing with the Soviet Union that the West began to devote a great deai of attention to scholarly investigation of the U.S.S.R. Thus, a large number of research methodologies and paradigms of inquiry were created and serious and sophisticated bodies of literature pertaining to the Soviet Union 
began to emerge. ${ }^{14}$ However, many of these research models prove, in this writer's view, to be unsatisfactory in that they attempt to utilize scientific discipline in an area that lacks sufficient amounts of scientific data. 15

A factor to be emphasized in regard to any scholarly research on the Soviet Union is that the Soviet regime, through the dissemination of the oral and written word, continually reveals a great deal about its perception, goals, and objectives on even the most crucial and sensitive issues. Thus, a careful analysis of official soviet documentation will provide an accurate means of assessing present Soviet views and of predicting future Soviet behavior.

The Soviet political system is, by its very nature, forced to reiterate the accepted political stance on any given issue throughout all levels of its administration. In so doing the Soviets provide outsiders with an accurate account of what to expect. ${ }^{16}$ This is due to the necessity for political uniformity, or a pretense thereof, that is vital to the Soviet political system. The only manner in which this can be affected is to continually expound the policies and views of the Kremlin to the point that there is no room for misapprehension at any level of the party or governmental apparatus. The oral and written word are not only the means by which the Soviet regime can provide essential guidance at al1 levels, but are also an effective means for avoiding confusion and uncertainty in any new policy or program. There have been very few major changes or policy implementations that have not been foreshadowed by extensive press campaigns and authoritative statements by the ruling hierarchy. ${ }^{17}$ If one is willing to read and scrutinize the often redundant, polemical, and ideologically-charged mass of official soviet documentation 
then a very accurate means of analysis, in this writer's view, will be employed. 18

Nowhere has the flow of official documentation on the part of the Soviet regime been as great as it has been in relation to the subject of detente. This is itself an aid to research. A careful reading of Soviet speeches, press reports, and radio broadcasts regarding detente has offered observers an impressive amount of material that is both informative and authoritative. Furthermore, especially as it relates to detente, there is a direct correlation between Soviet words and Soviet deeds. In nearly every aspect of detente, Soviet policies and actions have conformed very closely to the definition and spirit of detente that has been publicly espoused by the Soviet government. The Soviet government has not been reluctant to tell us what detente means; we in the West, however, are often reluctant to believe what they say.

\section{$\frac{\text { The Role of Ideology in the Formulation of }}{\text { Soviet Foreign Policy }}$}

Without a revolutionary theory there can be no revolutionary movement... The role of the vanguard can be fulfilled only by a party that is guided by an advanced theory

-V.I. Lenin

There is considerable debate regarding the role of ideology as a determining factor in the formulation of Soviet policy and as a variable that either should or should not be addressed in an analysis of Soviet behavior. It is certainly not within the scope of this paper to offer a definitive critique of this debate, the very subjective nature of which precludes the attainment of any authoritative or final solution. However, since the Soviet perceptions of detente, as seen through official Soviet sources, form the main focus of this report, it is imperative that 
ideology and its influence on the conduct of Soviet actions be clearly defined.

As is the case with most debates of this nature, two schools of thought exist with viewpoints diametrically opposed to the other. First, there are those that view Soviet ideology as no more than a ritualistic justification of action that is misleading and manipulative, as well as being subservient to the more traditional considerations of national interests and power politics as determining factors in the formulation of Soviet foreign policy. The antithesis of this argument is that ideology provides the Soviet hierarchy with a theoretical blueprint that transcends most other considerations and influences both the character and substance of Soviet political behavior. For many, the relative importance of ideology vis-a-vis more orthodox political considerations is a fluctuating phenomenon that is tempered by the substantive nature of the particular policy in question and, as such, must be viewed as something other than either an inflexible, ironclad dogma or an irrelevant, irrational political philosophy.

For those who view ideology as being subservient to the role of national interest in the formulation of Soviet foreign policy, complicated issues of Soviet foreign policy, such as the complex question of the Sino-Soviet rift, ${ }^{19}$ are cast in frameworks that totally ignore any ideological motivation on the part of either the Moscow or Peking regimes. 20 Furthermore, ideology, in this view is seen in the area of domestic policy as a means of self-justification and/or manipulation that serves as little more than a mechanism that can ensure compliance of the Soviet masses with the policies of the Kremlin regime. 21

In regard to foreign policy considerations this school of thought often dwells upon the "instrumental" character of ideology. In this respect, 
"ideology serves foreign policy as justification after the fact, while the principal concern of Soviet policy-makers in the realm of doctrine... is to retain a free hand for any opportune move, unrestricted by possible theoretical inhibitions."22 Ideology, in this light, is not a national guide to the operations of Soviet foreign policy at all, but is rather a post facto legitimizer of actions governed by the cause of national interest. Moreover, the invocation of Marxist-Leninist doctrine, as expressed by Alfred G. Meyer, goes beyond the function of legitimizing Soviet actions and acts as a deliberate "deceptive smokescreen" used to prevent others from understanding the true motivations underlying Soviet actions. 23

If detente has robbed ideology of its inspirational character as a guide to the conduct of foreign policy, it is quite natural that its corollary function as a legitimizer of Soviet actions should increase. Those who feel that detente has precipitated a further demise in the importance of ideology see a directly proportional relationship between the increase in the dimensions of detente and the need for a justification for the policies of the Soviet regime. This need, quite naturally, is served by ideology which now, more than ever, functions as a mere tool for self-legitimization. 24

Within the research framework of this dissertation ideology will be viewed as an important determining factor in the design and conduct of Soviet foreign policy. This is not to say that ideology alone serves as an inflexible guide to the pursuit of Soviet objectives or that all Soviet activity flows automatically from that ideology. Yet, at the same time, it should be noted that there is evidence that indicates that ideology still provides an inspirational source of guidance for the 
decision makers of the U.S.S.R.

It will be shown below that an important feature of MarxistLeninist ideology is the commitment to the objective of achieving the final victory of socialism over capitalism. Leading Soviet spokesmen have claimed, ${ }^{25}$ and noted Western commentators have observed, 26 that this ideological goal of transforming the world in the socialist order remains as a central component of long-term Soviet planning. Specific Soviet actions when examined within the confines of their own seemingly limited objectives and not as a small part in a much larger, more elaborate scheme, might very well seem to be dictated by the cause of national interest. This is true because of the need for foreign policy to be adaptive to the present historical environment in which it operates. When the long-term and ultimate objective of Soviet foreign affairs is disassociated from its short-term or regional goals, it is easy to confuse ideology and national interest. For many, these two factors, far from being mutually exclusive, operate together and often overlap. 27

It has been claimed by Adam B. Ulam that in the Soviet Union the reality of a modernized and industrialized society clashes with the ideological premises and hence "the U.S.S.R. is bent upon ideological and power expansion." 28 Perhaps the most concise manifestation of the problem of national interest in respect to ideology was inadvertently made by Fred Warner Neal in his testimony before a House subcommittee. Professor Neal first stated that Moscow was motivated to embark upon a detente policy for reasons of national interest, in this case, to insure national security vis-a-vis both Peking and Washington. In the very next sentence, however, it is claimed that "one of the reasons the Russians want to avoid war is to further the chances of achieving communism in the world. They reason 
that it cannot be built on the ruins of a thermonuclear conflict..."29 The fact that the ultimate end of communist ideology cannot be achieved in the aftermath of a catastrophic nuclear clash dictated the feasibility of the contemporary means of a detente with the major Soviet nuclear adversary. It can be argued that the protection of Soviet national security, the advancement of Soviet influence, and the augmentation of Soviet power and prestige are not necessarily objective ends of the Soviet state per se but are instead the functional means for the further advancement of the communist cause. In fact, one observer has noted that "Soviet ideology itself defines 'national interest,' 'power' and 'world revolution' in such a way as to make them virtually as indistinguishable and inseparable as the three sides of an equilateral triangle." 30 Zbigniew Brzezinski views the Soviet commitment to the goal of the worldwide socialist victory as infusing Soviet foreign policy with a "sense of continuity in purpose," and "universitality of goal," which clearly separates it from traditional policies of power politics:

Admittedly, Soviet foreign policy, especially in its shortterm aspects, is concerned with national security, frontiers, national power, etc. -- factors that inherently introduce similarities with Russia's traditional concerns. Quite unlike their predecessors, however, the Soviet leaders view these issues in terms of certain long-range perspectives and not as ends in themselves. 31

While the Kremlin hierarchy may well have consistently manipulated the masses, asking seemingly impossible sacrifices and demanding persistent patience in the name of ideology, this does not mean that ideological exhortation is a form of cruel chicanery perpetrated on the Soviet citizenry by a handful of priviledged leaders who believe none of what they say. As the noted team of sociologists, Inkeles, Bauer, and Kluckhohn state, "the leadership's use of ideology for cynical manipulation does not mean that 
the regime does not take ideas as such seriously -- quite the contrary." 32 To think otherwise is to represent ideology, in the words of R.N. Carew Hunt, "as a species of opium with which the Soviet leaders contrive to lull the people while taking care never to indulge in it themselves" thus attributing to them "an ability to dissociate themselves from the logic of their system -- an ability which it is unlikely they possess." 33

It has been noted that only a serious setback, which would weaken the Soviet position of influence and prestige, could force the Soviet Union to lose "its evangelical fervor and sense of imperial destiny and resign itself to function within the framework of limited objectives and circumscribed ends." 34 The present era of detente, and the immediate future within a detente structure, would not seem to augur any such serious setback. In fact, evidence suggests that the successes enjoyed by the Soviet Union in its foreign policy from 1972 to 1980 would seem to add to, rather than subtract from, the momentum the kremlin now has in the realm of foreign affairs. Summarizing the past decade of Soviet foreign policy, Leonid Brezhnev, for example, can paint a picture of Soviet advances that can only strengthen the Soviet position vis-a-vis the United States. Citing socialist gains in India, Vietnam, the Persian Gulf and elsewhere Brezhnev claims that Soviet-styled detente not only strengthened the "unity of the fraternal countries" but also served the interests of "the peoples who have freed themselves from colonial oppression and are engaged in the difficult task of constructing a new and independent life." 35 Denouncing the U.S. Teadership for "pursuing a line aimed at undermining detente and aggravating the international situation," Brezhnev can warn the United States, as follows: 
...the present day colonialists run the risk of miscalculating. We are no longer living in the prewar years, or even in the 1950's. Dozens of previously dependent countries have gained experience in independent life and policy.... They will not so easily renounce detente for the sake of American plans for world domination. For our part, we continue to favor the development of peaceful cooperation of all sorts with these

This correlation of world forces in favor of socialism, along with the proliferation of socialist principles, the strengthening of socialist internationalism and others, are assertions that the Soviet Union has been making for some time now. Taken in light of the present soviet position in international affairs, however, they show a Soviet position that from Moscow's perspective is free of any serious setbacks or loss of influence and prestige.

\section{Review of Pertinent Scholarly Literature}

This dissertation will attempt to provide a new perspective on a subject matter that is considered to be of great importance. It is interesting to note, however, that while a great deal of scholarly literature has addressed the topic of Soviet-American relations and of Soviet foreign policy in general, very little has been written in regard to the subject matter of detente per se. The subject of Soviet foreign policy is best presented in Adam B. U1am, Expansion and Coexistence: The History of Soviet Foreign Policy, 1917-1967 (New York: Praeger Publishers, 1968). Other notable contributions are: Herbert S. Dinerstein, Fifty Years of Soviet Foreign Policy (Baltimore: The John Hopkins Press, 1968), George F. Kennan, Russia and the West Under Lenin and Stalin (New York: New American Library, 1960), and Soviet Foreign Policy, 1917-1941 (Princeton, N.J.: Van Nostrand, 1960), Anatol Rapoport, The Big Two: Soviet-American Perceptions 
of Foreign Policy (New York: Pegasus, 1971), Adam B. U1am, The Rivals: America and Russia Since World War II (New York: Prager Publishers, 1971), Erik P. Hoffmann and Frederic J. Fleron, Jr., eds. The Conduct of Soviet Foreign Policy (Chicago: Aldine-Atherton, 1971), Zbigniew K. Brzezinski: The Soviet Bloc: Unity and Conflict (Cambridge: Harvard University Press, 1967), Vernon A. Aspaturian, ed. Process and Power in Soviet Foreign Policy (Boston: Little Brown and Co., 1971). Together these works constitute an exhaustive study of nearly every facet of U.S.-Soviet relations, and posit varying claims in regard to peaceful coexistence, the Cold War, containment, Soviet expansionism, and the like. Very few, if any, of these works, however, directly address the subject of Soviet-American or East-West detente or coexistence in a comprehensive manner. A notable contribution here is Albert L. Weeks, The Troubled Detente (New York: New York University Press, 1976). Other works include Gerald L. Steibel, Detente: Promises and Pitfalls (New York: Crane, Russak and Co., Inc., 1975), Jeffrey Simon, Ruling Communist Parties and Detente: A Documentary History (Washington, D.C.: American Enterprise Institute for Public Policy Research, 1975), and George Schwab and Henry Friedlander, eds. Detente in Historical Perspective (New York: Cyrco Press, 1975). Of al1 these studies those by Adam B. Ulam (especially his Expansion and Coexistence) Zbigniew K. Brzezinski, and George $F$. Kennan are considered by this writer to be the most authoritative and informative.

The subject of ideology in the Soviet Union, and its role in shaping foreign and domestic policy has received considerable attention in Western scholarly 7iterature. The most authoritative of these, in my view, is Brzezinski, Ideology and Power in Soviet Politics (New York: Praeger Publishers, 1962). Other contributions include: Michel Tatu, Power in the 
Kremlin From Khrushchev to Kosygin (New York: The Viking Press, 1968), Daniel Bel1, The End of Ideology: On the Exhaustion of Political Ideas in the 50's (New York: Collier Books, 1961), and "Ten Theories in Search of Reality: The Prediction of Soviet Behavior," in Aspaturian ed. Process and Power in Soviet Foreign Policy (Boston: Little Brown and Co., 1971), Alex Inkeles, Social Change in Soviet Russia (New York: Simon and Schuster, 1971), David Lane, Politics and Society in the USSR (New York:

Random House, 1971), Robert Conquest, Power and Policy in the USSR: The Struggle for Stalin's Succession (New York: Harper and Row, 1967), Leonard Schapiro, The Government and Politics of the Soviet Union (New York:

Vintage Books, 1965), and The Communist Party of the Soviet Union (New York: Random House, 1960), Merle Fainsod, How Russia is Ruled (Cambridge: Harvard University Press, 1967), Barrington Moore, Jr., Soviet Politics-The Dilemma of Power (Cambridge: Harvard University Press, 1961), Alfred G. Meyer, The Soviet Political System: An Interpretation (New York: Random House, 1965), Raymond A. Bauer, Alex Inkeles, and Clyde Kluckhohn, How the Soviet System Works (New York: Vintage Books, 1956), R. Judson Mitche11, "Continuity and Change in Soviet Ideology," Current History (October, 1975), Bayless Manning, "Goals, Ideology and Foreign Policy," Foreign Affairs (January, 1976), Jerry F. Hough, "The Soviet System: Petrification or Pluralism?" Problems of Communism (March-Apri1, 1972), Samuel L. Sharp, "National Interest: Key to Soviet Politics," Robert V. Daniels, "Doctrine and Foreign Policy," R.N. Carew Hunt, "The Importance of Doctrine," Adam B. Ulam, "Soviet Ideology and Soviet Foreign Policy," all in Hoffman and Fleron, eds. The Conduct of Soviet Foreign Policy (Chicago: AldineAtherton, 1971), Wol fgang Leonhard, Three Faces of Marxism (New York: Holt Rinehart and Winston, 1970), and Bertram D. Wolfe, "Communist Ideology 
and Soviet Foreign Policy," Foreign Affairs (October, 1962). This body of literature provides a thorough and complete presentation of the role of ideology and also represents a fairly wide spectrum of thought on the structure of the Soviet political system and the appropriate methodologies by which to study it. Of all these works, it is my belief that the most informative and accurate are those of Brzezinski and Carew Hunt on the subject of ideology and Conquest on the subject of investigative methodologies. 


\section{FOOTNOTES: CHAPTER I}

IV.I. Lenin, Selected Works (New York: International Publishers, 1943), Vol. VII, p. 282 .

${ }^{2}$ V.I. Lenin, "A Letter to American Workers," The Lenin Reader, ed. by Stefan T. Possony (Chicago: Henry Regnery Co., 1966), p. 261.

${ }^{3}$ Much of the skepticism and animosity that prevailed during this time between the United States and Soviet Russia is presented in E. Malcolm Carrol1, Soviet Communism and Western Opinion, 1919-1921 (Chapel Hill: University of North Carolina Press, 1965).

${ }^{4}$ Daniel Bell has authored what is generally viewed as the seminal work on this topic in his The End of Ideology: On the Exhaustion of Political Ideas in the '50's (New York: Collier Books, 1961).

${ }^{5}$ This viewpoint is adequately summarized in Samuel L. Sharp, "National Interest: Key to Soviet Politics," in The Conduct of Soviet Foreign Policy, ed. by Erik P. Hoffmann, and Frederic J. Fleron, Jr. (Chicago: Aldine-Atherton, 1971), Teresa Rakowski-Harmstone, "Socialist Internationalism and Eastern Europe," Survey, Vol. 22 (Winter, 1976), and Robert V. Daniels, "Doctrine and Foreign Policy," in The Conduct of Soviet Foreign Policy.

${ }^{6}$ See for example, Herbert $S$. Dinerstein, Fifty Years of Soviet Foreign Policy (Baltimore: The Johns Hopkins Press, 1968), p. 5, and Vernon V. Aspaturian, "Soviet Conceptions of Diplomacy," in Process and Power in Soviet Foreign Policy, ed. by Vernon V. Aspaturian (Boston: Little, Brown and Co., 1971), P. 350.

${ }^{7}$ A representative sample of this school of thought can be found in Barrington Moore, Jr., Soviet Politics - The Dilemma of Power (Cambridge, Mass.: Harvard University Press, 1951), William Zimmerman, Soviet Perspectives on International Relations, 1956-1967 (Princeton: Princeton University Press, 1969), especially pages 288-290, and Arthur Hartman, the Assistant Secretary of State for European Affairs, in his testimony before a House subcommittee hearing on the subject of detente in U.S. Congress, House, Committee on Foreign Affairs, Detente, Hearings, before the subcommittee on Europe of the Committee on Foreign Affairs, House of Representatives, 93rd Congress, 2nd Session, 1974, p. 72.

${ }^{8}$ Anatol Rapoport claims in this regard that such a view "becomes the crude image of an apocalyptic struggle between Good and Evil, found in the Soviet diatribes against the west and in the cliches of American crusading anti-Communists." See his The Big Two: Soviet-American Perceptions of Foreign Policy (New York: Pegasus, 1971), p. 19.

${ }^{9}$ John Kenneth Gaibraith, The New Industrial State (Boston: 
Houghton Miflin Co., 1967), p. 391.

10L.I. Brezhnev, Pravda, June 28, 1972, P. 1.

11 Michel Tatu, Power in the Kreml in from Khrushchev to Kosygin

(New York: The Viking Press, 1968), p. 16.

${ }^{12}$ Alex Inkeles, Social Change in Soviet Russia (New York: Simon and Schuster, 1971), p. ix.

13 Adam B. Ulam, Expansion and Coexistence. The History of Soviet Foreign Policy, 1917-1967 (New York: Praeger Publishers, 1968),

${ }^{14}$ There are a number of excellent sources that address themselves to the problem of methodological frameworks in regard to Soviet studies. I have referred here to three works which offer a summarization of many of the approaches in question, and which present an excellent bibliography for a more detailed analysis. Daniel Bell in his "Ten Theories in Search of Reality: The Prediction of Soviet Behavior," in Process and Power in Soviet Foreign Policy, ed. by Vernon V. Aspaturian (Boston: Little, Brown and $\left.\mathrm{Co}_{.}, 1971\right)$, pp. 289-323, has written what is generally regarded as the seminal article on the subject. More updated analyses of these paradigms and conceptual models are offered by: Jerry F. Hough, "The Soviet System: Petrification or Pluralism," Problems of Communism, XXI (March-April, 1972); David Lane, Politics and Society in the USSR (New York: Random House, 1971), pp. 175-202.

${ }^{15}$ A similar view is expressed in Robert Conquest Power and Policy in the U.S.S.R.: The Struggle for Stalin's Succession (New York: Harper and Row, 1967), p. 3 .

${ }^{16}$ George F. Kennan has criticized those who would not utilize this valuable source of information because it appeared too tendentious to be taken seriously. See his Russia and the West under Lenin and Stalin (New York: New American Library, 1960), p. vi.

17 Hough, "Petrification or Pluralism," p. 30.

${ }^{18}$ A similar view is expressed in Leonard Schapiro, The Government and Politics of the Soviet Union (New York: Vintage Books, 1965), p. 12.

${ }^{19}$ There are a host of sources which accurately analyze and evaluate the questions of the origins and consequences of the Sino-Soviet split. have found three to have merited special attention. Donald S. Zagoria, The Sino-Soviet Conflict (Princeton: Princeton University Press, 1961) and William E. Griffith, The Sino-Soviet Rift (Cambridge: M.I.T. Press, 1964), offer excellent book-length analyses of the schism between Moscow and Peking. A shorter, but equally excellent, discussion may be found in Zbigniew K. Brzezinski, The Soviet Bloc: Unity and Conflict (Cambridge: Harvard University Press, 1967), especially the chapter "The Sino-Soviet Conflict," pp. 397-432. 
${ }^{20}$ Foy D. Kohler, Understanding the Russians: A Citizen's Primer (New York: Harper and Row, 1970), p. 187.

${ }^{21}$ This view is expressed by David Lane in his Politics and Society in the USSR (New York: Random House, 1971), p. 214, Foy D. Kohler in his statement before the House subcommittee hearings on detente in Detente, Hearings, before the subcommittee on Europe of the Committee on Foreign Affairs, $p .74$, and by George $F$. Kennan in a panel discussion reported in Foy D. Kohler, and Mose L. Harvey, eds. The Soviet Union: Yesterday, Today, Tomorrow (Miami : University of Miami Press, 1975), p. 49.

${ }^{22}$ Daniels, "Doctrine and Foreign Policy," p. 164.

${ }^{23}$ Alfred G. Meyer, The Soviet Political System: An Interpretation (New York: Random House, 1965), p. 92.

${ }^{24}$ See for example R. Judson Mitchell, "Continuity and Change in Soviet Ideology," Current History, Vo1.69, No. 409 (October, 1975), pp. 137141 .

\section{${ }^{25}$ See for example L.I. Brezhnev, Pravda, February 25, 1976, p. 6. \\ ${ }^{26}$ Zbigniew Brzezinski, for one, claims that the ends, or the} "doctrinal component," of Soviet ideology have remained consistent, although the means of achieving those ends may have been altered. See his The Soviet Bloc: Unity and Conflict (Cambridge: Harvard University Press, 1967), p. 489. A brilliant expose on the subject of altering the "means" of communist ideology is offered by Richard Lowenthal, "Unreason and Revolution," reprinted in Comparative Politics: Notes and Readings, ed. by Roy C. McCridis and Bernard E. Brown (Homewood, 111.: The Dorsey Press, 1972), pp. 517-534.

27 See for example Bertram D. Wolfe, "Communist Ideology and Soviet Foreign Policy," Foreign Affairs, Vol. XLI, No. 1 (Oct., 1962), p. 153, and R.N. Carew Hunt, "The Importance of Doctrine," in The Conduct of Soviet Foreign Policy, p. 108.

${ }^{28}$ Adam B. Ulam, "Soviet Ideology and Soviet Foreign Policy," in The Conduct of Soviet Foreign Policy, p. 153.

${ }^{29}$ U.S. Congress, House, Detente, Hearings, p. 8.

${ }^{30}$ Aspaturian, Process and Power, p. 333.

${ }^{31}$ Zbigniew K. Brzezinski, Ideology and Power in Soviet Politics (New York: Praeger, 1962), p. 108.

${ }^{32}$ Raymond A. Bauer, Alex Inkeles and Clyde Kluckhohn, How the Soviet System Works (New York: Vintage Books, 1956), p. 35.

${ }^{33}$ Hunt, "Importance of Doctrine," Conduct of Soviet Foreign Policy, p. 107. 
${ }^{34}$ Merle Fainsod, How Russia is Ruled (Cambridge: Harvard

University Press, 1967), $\frac{\text { p. } 345 .}{34}$

${ }^{35}$ L. I. Brezhnev, Pravda, Feb. 23, 1980, p. 1, translated in The Current Digest of the Soviet Press, Vol. XXXII, No. 8 (March 26, ${ }^{36}$ Ibid. 


\section{H A P TER II}

THE IMPORTANCE OF DETENTE DURING THE BREZHNEV ERA

The Soviet Union claims that detente forms the very pillars on which its foreign policy is constructed. At the same time, the American government has claimed that detente is the only sane and rational guideline for the conduct of U.S. foreign policy. The U.S.S.R. views detente as a means by which to achieve communist objectives. The United States, meanwhile, sees detente as a means by which confrontations based on expansionist goals will be eliminated. The Soviet Union views detente as a catalyst for the intensification of the ideological struggle. The United States perceives detente as a way to reach a reconciliation with Moscow. For one it means change in the world; for the other, stability. Both parties obviously have vastly different perceptions of the same policy by which they have mutually agreed to abide. Despite the major differences in their understanding of detente, leading spokesmen in both the Soviet Union and the United States have agreed on one major point; detente is the single most important policy in the realm of international relations.

This view was echoed incessantly in both Washington and Moscow from 1972 to 1976. In the ensuing four years the Kremlin regime did not change the party line in this regard and, to this day asserts that detente forms the very nucleus of Soviet foreign policy. On the other hand, the United

States has diminished its praise of detente in light of the Soviet intervention in Afghanistan, which some American observers feel constitutes a flagrant violation of the principles of detente. The Soviets, for their part, 
see this action as perfectly consistent with detente which never precluded and, in fact, fostered the proliferation and expansion of the peace-loving principles of socialist internationalism.

Leonid Brezhnev has charged in this regard that "imperialist and Peking progaganda are deliberately and shamelessly distorting the Soviet Union's role in Afghan affairs." 1 Brezhnev has also claimed that the stern American response to Soviet activity has seriously worsened the international situation. In the words of Brezhnev:

Our Party's consistent and creative pursuit of a course aimed at peace, detente and disarmament and at the implementation of the Peace Program advanced by the $24 \mathrm{th}$ and $25 \mathrm{th}$ C.P.S.U. Congresses has made it possible to accomplish a great deal....

But, unfortunately, as the 1970's end and the 1980's begin the international situation has worsened appreciably. The people ought to know the truth about who is responsible for this. I can answer without reservation--the blame rests with the imperialist forces, and above all with certain circles in the U.S.2

Brezhnev then can clearly identify the fact that the United States did not understand the meaning of Soviet actions in Afghanistan, within the framework of detente:

Today the opponents of peace and detente are trying to capitalize on the events in Afghanistan. Mountains of lies are being heaped up around these events, and a shameless anti-Soviet campaign is underway. What actually happened in Afghanistan?3

What actually happened, in Brezhnev's view, is that the Soviet Union rendered support to "revolutionary Afghanistan" in the face of an undeclared war being waged there by counter-revolutionary imperialist forces. The Soviet Union, of course, was asked to come to the defense of the revolutionary forces in Afghanistan. In summary Brezhnev can then claim: 
For our part, we warned the parties concerned that if the aggression did not stop that we would not abandon the Afghan people in their time of need. And, as is known, we do what we say we are going to do.

It will be argued in greater detail below that soviet support for anti-imperialist revolutionary forces in the developing nations is not only above condemnation by the United States, but is also an integral component of the policy of detente. The reasons for the recent American re-assessment of the detente policy and the Soviet's unwillingness to depart from detente in 1980, however, are topics that are clearly beyond the scope of this present analysis. The focus of the present chapter will be on the period from 1972 to 1976 when the latest detente model was fully developed, and when both sides agreed that detente was on a level of unmatched significance.

While present events may go a long way in reshaping the emphasis placed on detente, it was the period under discussion here that provided detente with the acclaim, support, and formal diplomatic recognition that it still enjoys in the minds of many to this day. Moreover, this time span manifested some of the misunderstandings of the policy that have caused a number of concerns and problems which still persist in 1981.

In addressing detente, the political analyst could question how detente, with two vastly different perceptions, one being the near antithesis of the other, became the most important component of the foreign policy of two adversaries. The answer, of course lies in the particular interpretation of detente, as it exists in both Moscow and Washington.

In the first place, it should be noted that detente, in this writer's view, is a very important variable in the present international arena. The rationale for this claim, however, is different from those of the architects of detente, who are the objects of this analysis. A 
representative sampling of authoritative spokesmen from both Moscow and Washington shows that detente, whether understood or misunderstood, liked or disliked, is viewed as a policy of great importance in both capitals.

There has been no dearth of authoritative spokesmen in both the Soviet Union and the United States who, at the risk of overselling their product, sang the virtues of detente and acclaimed it as a policy of unprecedented importance. It must be remembered, of course, that more than one political career has been gambled on the successful acceptance of detente, and many glowing assertions in this regard must be taken with more than one grain of salt.

\section{The American Perception of the Importance of Detente}

Former American Secretary of State Henry Kissinger, one of the main architects of the detente policy in the United States, and its most ardent supporter, depicts the importance of detente in the following terms:

Since the dawn of the nuclear age, the world's fears of catastrophe and its hopes for peace have hinged on the relationship between the United States and the Soviet Union.

In an era when two nations have the power to visit utter devastation on the world in a matter of hours, there can be no greater imperative than assuring that the relationship between the superpowers be managed effectively and rationaliy. 5

The perception of detente as the only sane alternative to the waging of full-scale nuclear war appeared to be the highest accolade that American proponents of detente could give to this policy. At the same time, this theme tended to epitomize the basic essence of detente as perceived by American policy makers. Of all the spokesmen in the United States who repeated this familiar line, none was more persistent than Kissinger: 
...But in the nuclear age, when casualties in a general nuclear war will involve hundreds of millions in a matter of days the use of force threatens utter catastrophe. It is our policy to contain Soviet power without global war, to avoid abdication as well as unnecessary confrontation...

This is what is meant by the process called detente. 6

One could logically argue that such a formula, that depicts detente and thermonuclear confrontation as mutually exclusive activities, is overly simplistic. To do so might give credence to the argument that detente or a thermonuclear war are somehow the only two options available to American and Soviet decision makers. Detente may be seen more properly as something other than the sole variable preventing the exacerbation of Soviet-American tensions to the point of provoking a thermonuclear exchange. Zbigniew Brzezinski, an outspoken critic of Kissinger-styled detente, noted, in this regard, that "the alternative to detente is not war but a variety of intermediate positions." The crux of this argument is, as Brzezinski points out: "When there was no detente, there was no war either." 7

Such an argument did not deter the American proponents of detente from asserting that detente found its significance in its contribution to the prevention of a thermonuclear holocaust. This dictum became the accepted stance of the Nixon and Ford administrations. As echoed by the Under Secretary of State for Political Affairs, Joseph J. Sisco:

Our efforts to strengthen relations reciprocaliy between the United States and the Soviet Union must continue; for this relationship will probably determine more than any other single factor whether our hopes for peace and stability in the world are eventually realized.8

Much the same view was expressed by Deputy Secretary of State Kenneth Rush, who questioned the rationale for not pursuing a detente relationship with the Soviet Union: 
Detente is founded on the belief that when nations have the power to destroy each other - and the world - it is irrational to make the threat of holocaust the only base for peace. Reason demands an effort to place relationships on a more stable
and positive basis.

Yet, more than anyone else, it was Kissinger who presented the most detailed defense of a doctrine that was not universally received in all segments of American society. Kissinger often repeated this line in a manner that left no room for misapprehension:

There can be no peaceful international order without a constructive relationship between the United States and the Soviet Union - the two nations with the power to destroy
mankind.

Moreover, detente in the view of the former Secretary of State, was the only feasible alternative facing American policy makers:

In the age of thermonuclear weapons and strategic equality, the relaxation of tensions is the only responsible course and the only policy that can be pursued by any administration charged with the responsibility for the lives of Americans... When both sides have the military power to annihilate mankind it would be utter recklessness to invite tension needlessly.

This formula therefore, provided a capsule summary of the American perception of detente. As will be seen below, the Soviets hold a similar view, but with significant variations added.

\section{The Significance of Detente: The Soviet View}

The perception of detente as an immensely important doctrine was not a characteristic that was indigenous to statesmen in Washington. The Soviet ruling hierarchy, on a number of occasions, repeated the need for pursuing a policy based on the formula of easing tensions and removing the threat of thermonuclear war. According to the official soviet line, detente is a course of action that must be implemented, and eventually made irreversible, so that the two superpowers can move from an era of 
confrontation and threats of war to one of negotiation and of stabilizing peace.

In his keynote address at the 25th Congress of the Communist Party of the Soviet Union, Leonid Brezhnev the General Secretary of the C.P.S.U. and Chairman of the Presidium of the Supreme Soviet, elevated this doctrine to the level of official policy:

...we have every reason to confidently state that the improvement of the international situation is irrefutable evidence that the securing of a permanent peace is not only a good intention but a truly realistic goal...

The improvement in our relations with the United States of America, the capitalist world's greatest power, has, of course, been of tremendous importance in reducing the threat of a new world war and of consolidating peace. 12

It must be noted that the congresses of the C.P.S.U. are generally regarded as the most important forums for the Soviet regime to articulate, in detailed fashion, the official policy line on all foreign and domestic issues. Moreover, the keynote address delivered by Brezhnev was acclaimed as the single most important component of the Congress in regard to the official Soviet perception of any issue. Hence, when Brezhnev stated in his address that "the main element in our relations with the capitalist states has been the struggle to assert the principles of peacefur coexistence," 13 and that detente has helped to strengthen peace, "and lessen the danger of the outbreak of a nuclear war, "14 it then became an accepted fact in the Soviet view, that detente was a policy of great importance.

The Soviet Union, having become disenchanted with the foreign policy of President Carter, unleashed a major propaganda fusillade against the new American president in the early months of his administration. This process certainly underscored the fragile and uneasy state of U.S.Soviet relations. Yet, in no manner did the U.S.S.R. diminish the 
importance of pursuing the policy of detente. Thus, Brezhnev, in discussing Soviet-American relations on French television, claimed:

The consolidation of peace is one of the most important guarantees of the greatest human right, the right to live...

I will say again and again: The cause of peace and detente must be the cause of everyone. What has been achieved toward consolidating peace is not a limit, but a starting point for a new activity. 15

While watching the erosion of a more amiable U.S.-Soviet rapport that existed during previous administrations, Soviet commentators still portrayed detente as a policy of unequalled significance:

The living process of detente, the development of various forms of cooperation among states and the affirmation of the principles of peaceful coexistence in international relations - this is a reality which is increasingly determining the course and nature of events on the world scene. 16

Brezhnev has also added a feeling of optimism, or hope, that detente would not become stagnated with the changing of the guard in the White House:

I have had many occasions to talk about the favorable influence of detente on the entire international climate. I see no reasons to make any changes in this estimate. However, it would be correct to note that in some places detente has engendered a certain complacency. 17

\section{The 1972 "Declaration of Basic Principles"}

One of the major hypotheses of this report is that detente is not a process that is limited to the present state of U.S.-Soviet relations. Rather, it will be argued that detente has been in existence from the outset of the relationships between Soviet Russia and the United States. 18 However, evidence suggests that the latest historical era in the life of detente was given birth by the Brezhnev regime. This process reached its full consumation in Moscow in May of 1972 with the co-signing 
of the "Declaration of Basic Principles of Mutual Relations Between the United States of America and the Union of Soviet Socialist Republics." This "Declaration of Basic Principles," more than any other document, has defined the nature, scope, and intent of detente. As such, this document, and the reaction it has engendered, provides a barometer for measuring the perceived significance of detente.

Of the nine separate accords signed by Nixon and Brezhnev at the Moscow summit, the Soviet Union has attached the greatest significance to the "Declaration of Basic Principles." Yuri Chernov, in an authoritative Pravda article of June 15, 1972, asserted that this declaration "deserves special attention above all else" in regard to the summit talks. It was, as Chernov declared, "the first document between the U.S.S.R. and the U.S.A. to give international legal form to relations between the two sides on the basis of the principles of peaceful co-existence." 19 As such, this document attains special significance in the Soviet view:

It is difficult to overestimate the importance of the fact that the U.S.S.R. and the U.S.A., the powers with the greatest military potential, powers belonging to different social systems, have agreed to, by what is for all practical purposes, a treaty, to build their relations on this basis. 20

Georgi Arbatov, the director of the Institute of the U.S.A. of the U.S.S.R. Academy of Sciences, and an acknowledged Soviet specialist on American affairs saw the "Declaration" as a "far reaching document filled with profound meaning," and one that "essentially formulates the international legal principles for relations between the two states." 21 Arbatov, furthermore likened the document to the most significant events in the history of U.S.-Soviet relations, claiming that the "Declaration of Basic Principles" and the Moscow summit as a whole, 
...may very well become a landmark comparable in

significance to such events as the establishment of diplomatic relations between the two countries in 1933, and their cooperation during the Second World War. In other words, the results of the talks may open the way to an important shift in Soviet-American relations...2

Much of this euphoria has been tempered by the realities of events following the summit. While many of the expectations of May of 1972 have not been realized, the Soviet Union did not diminish the significance of the Moscow Declaration. Brezhnev, in his address to the 25 th C.P.S.U. Congress reaffirmed the importance of the document calling it the main result "of the development of Soviet-American relations in the past five years." 23 Likewise, Arbatov in a Pravda article of April, 1976 asserted that "if we consider not only the number of agreements (signed by the U.S. and the U.S.S.R.), but also their substance, it is difficult to overestimate the importance of such documents as the Declaration of Basic Principles of Relations between the U.S.S.R. and the U.S..." 24

Detente, obviously, involves far more than the signing of a joint document. Yet, it is testimony to the Soviet adherence to the concept itself that these accords are viewed as the most significant agreement in the history of U.S.-Soviet relations. In discussing SovietAmerican relations from 1972 to 1977, Soviet commentator Viadimir Bolshakov cast that five year period in terms of the "five year anniversary" of the signing of the basic principles document:

It will be five years on Sunday since the General Secretary of the Soviet Communist Party and the president of the United States signed in Moscow the basic principles of relations between the two countries.

The agreement...did a great deal to improve SovietAmerican relations, put an end to the cold war, and move from confrontation to mutual cooperation. The main document was the basic principles of mutual relations. It became the political and legal foundation for the new relationship. 25 
Soviet commentators, it can be reasoned, look upon detente, as defined in the "Declaration of Basic Principles," as a legalistic endorsement by the United States of the Soviet policy of peaceful coexistence. The American view is clearly different. Brzezinski, although critical of the policy, did not diminish the significance of detente as defined in the basic principles declaration. As he claimed, the declaration signalled "a significant codification of the 'rules of the game' under which the rivalry is to be conducted" and signifies "a change toward a more mixed relationship." 26 In Brzezinski's view the declaration, and the summit in general, "suggest that the cold war is gradually being transformed from an implicity apocalyptic conflict to an explicity relativistic competition." 27 Similarly, Richard Nixon viewed the "Declaration of Basic Principles" as one of his greatest achievements at the Moscow summit. In a report to the Congress, Nixon highlighted the fact that the two countries have "established a set of basic principles to govern our relations." This, in the President's view, marked the first time in the postwar era that the two countries had established "a code of conduct that both sides could accept as the basis for regulating their competition and channeling their efforts toward more constructive endeavors." 28 In this light, Nixon sees the Moscow Declaration as the ultimate achievement of the summit and a document that "can provide a solid framework for the future development of better American-Soviet relations."29 The Declaration is then coordinated with the overall perception of the American government in regard to detente. As Nixon declared before a joint session of the Congress, the basic principles of detente can deter the two countries from engaging in a nuclear war and, in his words, "in a nuclear war there could be no winners, only losers." 30 
The Global Nature of Detente

An important aspect of detente is its ability to transcend a bi-lateral Soviet-American relationship. The Soviet perception of detente allows for the dissemenation of socialist principles, support for wars of national liberation, and the Soviet ability to "create conditions favorable for the spread of socialism." From this perspective, detente undertakes a global significance. This worldwide significance of detente is also understood, but for different reasons, by the American government. Former Deputy Secretary of State, Kenneth Rush, for example, was able to deny any limited Soviet-American interests in detente:

We strive for broader areas of detente in the cause of global tranquility and heightened prosperity. This in no way is a condominium between the Soviet and American superpowers, but an engagement in the interests of a 11.31

Former president Gerald Ford, while acknowledging the necessity of "pushing back the spector of nuclear war" by concluding bi-lateral arms control accords, ${ }^{32}$ maintained the belief that detente supersedes any limited Soviet-American interests:

...it would be very unwise for a president, me or anyone else, to abandon detente. I think that detente is in the best interest of this country. It is in the best interest of world stability, world peace.

And for us to abandon this working relationship and to go back to a cold war, in my opinion, would be very unwise for us in the United States and the world as a whole. 33

One of the more important residual effects of detente is the impact that it has had on the nations within the communist world. It will be demonstrated below, for example, that the U.S.-Soviet detente has had a direct bearing on the Soviet-Chinese relationship. The U.S.S.R. has repeatedly charged that the U.S. is willing now to "play its China card" as a tool of anti-Soviet activity. It has also been claimed that the fear 
of a meaningful, and perhaps exclusive U.S.-C.P.R. rapprochement was one of the primary factors motivating the Soviet Union to embark on the latest detente course.

There are many who see the U.S.-Soviet detente as having a tempering effect on Soviet relations with the Warsaw Pact bloc of countries. This is often seen as the result of the necessity for the U.S.S.R. to maintain a reasonably moderate posture in the face of Western demands for increased liberalization within the Eastern European area. It has been shown, in the past, that the Soviet Union will not tolerate direct or indirect manifestations of ideological relaxation, ideological schism, political laxity, or "liberalization" in this region. These costs appear to be too high a price for the Soviets to pay for any positive image that might be deemed necessary during a period of East-West detente. In addition, such factors are at odds with the scope and purpose of detente which, in the Soviet view, does not allow for any relaxation of ideological vigilance by the "fraternal countries" of the socialist commonwealth. Yet, as two noted specialists of Eastern Europe have claimed, "detente has apparently affected intra-C.E.M.A. relations to the extent that the Soviet pursuit of a positive image in the West moderates their tactics, if not their ultimate goals." 34

Another important area in the sense of the global significance of detente, outside of the bi-lateral U.S.-Soviet equation, is in the reaim of domestic policies within the U.S.S.R. Specifically, this relates to the ideological backlash that is often a result of the easing of tensions abroad. It can be argued, in this regard that the soviet communist Party requires a menacing foreign threat to fully maximize ideological purity at home. As was mentioned above, this is oftentimes a reflection 
of the manipulative and cynical aspects of Soviet ideology that is most clearly reflected in the domestic affairs of the U.S.S.R. For a good many years the United States played the role of the foreign menace quite admirably. The United States was accused of being the bastion of decadent capitalist-imperialist oppression, the suppressor of national liberation movements, and the main obstacle to the peace-loving foreign policy of the Soviet Union. During an era of detente, with its expansion of political, cultural, athletic, and scientific contacts, this foreign enemy may well appear to be less ominous. A domestic response then becomes necessary. Stated very simply this foreign/domestic equation would read as follows: the greater the relaxation of tensions with the West and the greater the number of contacts with the West, the greater is the need to insure ideological vigilance and conformity within the realm of socialist nations in general, and within the Soviet Union in particular.

We in the West may find that some of the tangible results of Soviet-American detente outside of foreign policy, may well be the ideological retrenchment of the communist world, a reinforcement of "Stalinist" ideological controls, and a tightening of the screws of conformity. In this light, Kissinger had no qualms about presenting a tempting array of Western-styled innovations to the communist world, apparently regardiess of their consequences:

The winds of change are blowing from the West; the ideals of liberty and the challenge of technical innovation come from the West. The efforts of the Communist countries to participate in the rest of the world after decades of autarchy are a sign of the vigor and attraction of our economic system. These are assets of our diplomacy which we should be prepared to use. 35

Many analysts saw the use of such "diplomacy" and the Soviet response to it as the most important aspect of detente and the most 
significant development in regard to the fate of Soviet dissidents, intellectuals, and minority nationalities in years. Alexander Solzhenitsyn has expressed his fears that detente may well be "encouraging new acts of brutality and persecution." This has become possibie, according to Solzhenitsyn when "any acts of cruelty, and even brutality by one side toward its own citizens and its neighboring peoples is hastily and near-sightedly accepted by the proponents of detente as in no way standing in the way of detente."136 The importance of detente, in the view of Sovietologist Klaus Mehnert, rested with the fact that it may well serve as the fulcrum for such new acts of persecution. In discussing the plight of intellectuals, Professor Mehnert claimed that it is a fact that "the more there is detente (and that means, the more Western ideas come into the Soviet Union), the more repression the Soviet leaders will use against their intellectuals who are the people most exposed to Western ideas." 37 Similarly, David Zilberman, an emigre Soviet intellectual, believes that detente is of unparalleled importance because of its creation of increasing amounts of "compensative compression and growth of tensions" within Soviet society. ${ }^{38}$ In the same regard, the fate of the many diverse minority nationalities within the Soviet Union has been seen as being subject to the whims of Soviet-styled detente:

If the process of detente is pursued without a keen awareness of this multi-national complexion of the U.S.S.R., we may find ourselves by virtue of our economic contributions guaranteeing the permanent captivity of the many nations of the U.S.S.R. 39

With these heavy prices, detente logically presents the United States, in Kissinger's words with "one challenge unprecedented in its own history and another challenge without precedent in the history of the world." 40 Yet, the primacy of this challenge is represented in terms of 
the supposed consequence of its failure; thermonuclear war:

Historically a conflict of ideology and geopolitical interest such as now characterized the international scene has almost invariably led to war. But in the age of strategic equality, humanity could not survive such a repetition of history. War would mean mutual suicide. 41

Echoing the same theme, Winston Lord, the former Director of the Policy Planning Staff of the State Department, has stated that this repetition of history cannot be tolerated and that it is imperative to abandon the traditional oscillation between relaxing and exacerbating tensions:

For Americans, the most fundamental challenge is to pursue a steady, long-term course with the Soviet Union. It is time we left behind our traditional fluctuation between euphoria and gloom, between good will and indignation. 42

In citing the "long-term" nature of the detente relationship as it exists today, Lord has underscored one of the central considerations of this process, its nearly-guaranteed existence in one form or another for the foreseeable future. Thus, Brezhnev can call for the creation of an "irreversible" detente relationship, and a firm commitment to never abandon this relaxation and return to a cold war era when as he stated, disagreements are settled not by "peaceful political means," but by "force, threats, and sabre rattling." 43

Those who see detente as the sole means of preventing a thermonuclear war have made this long-term characteristic a fact that is simply true by definition. If the alternative to detente is nuclear war, which, as the formula goes, would mean either mutual suicide or total destruction of one system, then detente will be with us as long as Soviet-American relations exist. Hence, Kissinger can claim that "for the first time in our history, we face the stark reality that the challenge is unending, 
that there is no easy and surely no final answer." 44 In much the same manner, Marshall Shulman sees the evolutionary nature of detente which indicates that its final fruition will be seen at some future time:

Under favorable conditions this 'limited detente' may evolve through the decades to a later stage in which the cooperative elements can be strengthened and the Soviet Union can be drawn into a more constructive role in working toward the strengthening of the international system, as opposed to the condition of international violence and anarchy which is the alternative confronting the world. ${ }^{4}$

Detente has also been seen as a phenomenon that will outlive any presidential administration. In the words of former Assistant Secretary of State for European Affairs, Arthur A. Hartman:

This (detente in the face of Soviet military might) is not a problem which confronts this Administration only. It will be a problem for the next Administration and the next one after that. Indeed, I think that it will be a problem for Americans for at least the lifetime of every person in this room. 46

Detente is seen from a number of different perspectives. While none of these viewpoints agree on why detente is of such importance, they all concur in the fact that it is a concept of great significance. Detente may be seen as the deterrent to a thermonuclear war, the fuicrum for socialist expansion, the catalyst for ideological and social repression, or an irreversible and permanent fixture in international relations. Yet, in all these cases, the significance of detente is not overlooked. This is certainly true of the Soviet perception. For reasons to be outlined below, the Soviet Union worked diligentiy to foster a U.S.Soviet relationship based on the principles of detente. Soviet goals and objectives, it will be argued, could not be achieved with an antagonistic U.S.-Soviet posture. Detente provided the means by which many of these objectives could be realized without drastically increasing any risks to Soviet interests. It is not surprising, therefore, that the 
U.S.S.R. made every attempt to foster an image of detente as the single most important phenomenon in international relations. In the words of Arbatov:

In our time the restructuring of relations between the U.S.S.R. and the U.S. in the spirit of peace, greater mutual understanding and cooperation has become one of the cardinal questions of international 1 ife. 47

Likewise, an influential Pravda editorial signed by "commentator" expressed the same view:

In the overall process of positive changes taking place in the world, a significant place is being held by U.S.S.R.U.S. relations...

The strengthening of relations of peaceful co-existence between the states with different social systems and the development of mutually advantageous and constructive cooperation between them is becoming the dominating feature of the international situation. 48

In his address at the Helsinki Conference on Security and Cooperation in Europe, Brezhnev highlighted the major accomplishment of that meeting:

In our view, the main result of the conference is that it is making international detente increasingly substantive. It is precisely the materialization of detente that is the essence of the matter...49

A manifestation of the importance of detente in the Soviet view was given with the publication of the new "Brezhnev Constitution" of the U.S.S.R. This document, which replaced the 1936 "Stalin Constitution," contained the first constitutional reference to foreign policy. The foreign policy chapter provided a concise capsule summary of the Soviet perception of detente; its goals, objectives and significance:

The Soviet state shall consistentiy pursue the Leninist policy of peace...

The foreign policy of the U.S.S.R. shall be aimed at insuring favorable international conditions for the building of communism within the U.S.S.R., at strengthening the positions of world socialism, supporting the struggle of peoples for national liberation and social progress, 
preventing wars of aggression and consistently imple-

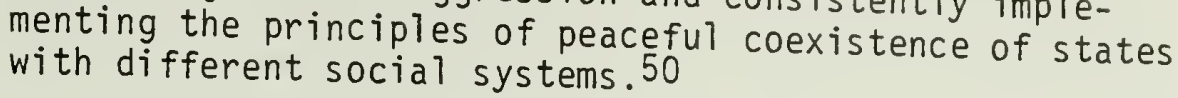

It is understandable that Soviet commentators would devote a good deal of time to analyzing the new constitution. Yet, it is significant that the greatest amount of attention was given to the foreign policy section of the constitution. The inordinate number of editorials and commentaries that addressed the foreign policy articles of the constitution (encompassing but 2 of the 173 articles in the entire document) gave testimony to the level of significance that the Soviet regime attached to detente. Thus, detente was referred to as a policy "elevated in the draft of the new constitution to the rank of a law of the Soviet state's activity both in domestic and foreign policy." 51 From the Soviet perspective, the new constitution, which "legislatively enshrined the goals and principles of the country's foreign policy line" has made detente a legal Soviet commitment. 52

The ensuing chapters of this study will address the reasons for the Soviet insistence on maintaining detente and elevating it to a position of law. At the present time it must be remembered that this perception was not unique to the Soviet Union. Professor Fred Warner Neal, an expert on Soviet-American affairs echoed the same theme:

I consider the present movement toward an AmericanSoviet detente to be the most significant and salutary development in American foreign policy since the end of World War II. The Declaration of Principles which President Nixon signed in Moscow in 1972, provides, it seems to me, the basis for ending the cold war...a definitive ending of the cold war is about the best thing imaginable that could happen for all of us. And that is precisely what an American-Soviet detente is a 11 about. 53

Even Solzhenitsyn, with his grave concerns about the suppression of human rights, can claim that "detente is not only necessary, but 
mankind's only salvation, and an urgent need of our times, more powerful than the intentions and decisions of individual political leaders..."54 The Nixon administration provided the most glowing praise for a procedure that formed the core of its foreign policy. In the words of Assistant Secretary Hartman, detente is "a policy of unique importance for all of us," and "the basic international problem of our time - perhaps of this whole half century..." ${ }^{55}$ Kissinger, of course, was even stronger in his comments and felt that "the future of mankind requires coexistence with the Soviet Union" because, as he claimed, "we owe future generations more hopeful prospects than a delicate equilibrium of awesome forces." 56 Nixon, felt that, as a result of the new era of detente, "never have two peoples had a greater challenge or a greater goal." 57 According to the former president "an unparalleled opportunity has been placed in America's hands" which, in his words, could "lead the world up out of the lowlands of constant war and onto the high plateau of lasting peace. "58

Much of this post-Moscow summit euphoria has, of course, been 1ost. Yet, as we have seen, the Soviet Union has not decreased its emphasis on detente. In the early months of the Carter administration the same viewpoints were being expressed in regard to deterte. Brzezinski, notwithstanding his direct criticism of Kissinger/Nixon-styled detente, could still claim that detente provided "a truly creative and historically novel framework" for the conduct of U.S.-Soviet relations. 59 Carter himself, although providing the catalyst for much of the de-emphasis of detente from the American perspective, still felt that detente with the Soviet Union was a policy that he would pursue "earnestly, constantly, and sincerely." 60 According to Vice President Mondale, detente provided the forum by which the two countries could "talk where before it was only 
possible to confront one another in deadly and undiminished hostility. And it is imperative that we continue this dialogue, ever seeking to expand its depth and compass."61

\section{Detente and the Pursuit of Soviet Objectives}

The evidence presented would show that detente, for a variety of reasons, has been accorded a position of unmatched significance. The question that still remains is: where does the true significance of detente actually rest?

While this writer is in agreement with the fact that SovietAmerican detente is of unique and unmatched importance, the reasoning outlined above is seen as insufficient. In the first place, detente would not seem to be the only rational option available to American decision makers charged with the responsibility of safeguarding the interests of the United States. Nor does it appear that detente should become an irreversible policy that will stay with us for the foreseable future. Detente, it can be argued, should not be viewed as the only defense against a possible thermonuclear confrontation with the Soviet Union. None of this is to say that an exacerbation of tensions in the thermonuclear age is necessarily in the best interests of either side. Yet, it would seem that the prevention of such a holocaust could be achieved by establishing a Soviet-American posture that is not totally dependent on a full-scale detente relationship as defined at the Moscow summit in 1972 and implemented in the years following. In short, the argument for detente, as depicted in the following formula, would seem to be insufficient: 
Let us remember that we seek detente with the Soviet Union for one overwhelming reason: Both countries have the capability to destroy each other - and most of the rest of the world in the process. Thus, both of us have an overriding obligation to do all in our power to prevent such a
catastrophe.62

It goes without saying that the preservation of peace in the thermonuclear age, and the prevention of a thermonuclear exchange are issues of importance. Yet, there are two caveats that must be mentioned here. Both of these considerations would, in this writer's view, belie the belief that detente solely serves the cause of peace in the thermonuclear age, and, as such, has no present alternative.

In the first place, any detente, even on the most cordial and harmonious of terms, cannot expect to eliminate the areas of concern that might eventually provide the basis for a direct confrontation. There is no reason to believe, nor any concrete evidence to suggest, that the Soviet Union will acquiesce in any agreement that would reduce the level of strategic conventional military parity that now exists between the two rival superpowers. It will be outlined in detail below that Soviet foreign policy in the contemporary era of detente, requires a military equation that is based on nothing less than parity with the West. It is precisely this parity that will maintain the constant threat of a thermonuclear war.

Secondly, detente, by allowing incremental and "non-threatening" forms of Soviet expansion, may eventually lead to a position where the threat of the use of strategic weaponry may become a very real American option. Detente, as perceived by the Soviet Union, may very well exacerbate the tensions and animosities that it was created to eliminate. The Soviet perception of detente, as noted earlier, is based on: the improvement of the correlation of the forces in the world in favor of the 
socialist camp; the realization by the West that any attempt to thwart socialist expansion is useless; the realization of the growing military might of the Soviet Union; and the full understanding by the United States that it has no choice but to adhere to the Soviet policy of detente with the socialist camp. Furthermore, detente, according to the Soviet perception, creates favorable conditions, not only for the growth of communism within the U.S.S.R., but for augmenting the principles of socialism in those nations seeking national liberation, and the nations of world capitalism, as well.

It is not surprising therefore, that a number of crises and areas of direct conflict in American-Soviet interests have arisen since the 1972 Moscow summit. Tensions in southern Africa in general, and Angola in particular, the October, 1973 Mideast War, the revolution and crisis in Iran, the Soviet invasion of Afghanistan and others have all served as testimony to the Soviet need to fulfill its expansionistic destiny. These crises should not be seen as breakdowns in detente, or a threat to detente; they would more accurately be viewed as inherent components of the Soviet perception of detente.

Thus, the true importance of detente may be seen as resting with the fact that it is a detailed Soviet blueprint for action. Moreover, detente in the Soviet view, is designed primarily to assist in the expansion of Soviet prestige and power and the placing of the United States under a system of unilateral restraints. As such, detente must be fully respected. Yet this respect should not be in the form of a commitment to an idealistic faith in a doctrine that can save the world from the horrors of a thermonuclear catastrophe. Rather, it should be in the form of a respect that must be shown to a formidable and worthy oponent 
If detente is pursued within the framework of the Soviet perception then it could also be a process that generates a good deal of concern and trepidation. Detente could easily lead to a series of geopolitical losses and constraints that could speli a period of rapid Soviet expansion and eventual communist domination. When Brezhnev claims that the Soviet Union intends "to pursue a policy of detente, striving to extend it to every region of the globe, "63 we in the United States might do well to reflect a moment before extending our fuil support to his wishes.

It will be shown beiow that the Soviet cause has been served very ably by detente. To demonstrate this, and to show how the Soviets arrived at their perception and understanding of detente in 1972, it is necessary to trace the historical development of this process. By so doing both the historical and ideological continuity of detente from 1918 to 1980 will be more clearly manifested. In addition, the motives and aspirations inherent in detente from the Soviet perspective should become much more apparent. 


\section{FOOTNOTES: CHAPTER II}

1L.I. Brezhnev, Pravda, January 13, 1980, p. 1.

2 Ibid.

${ }^{3}$ Ibid.

${ }^{4}$ Ibid.

${ }^{5}$ Henry A. Kissinger, Speech delivered in Boston, Massachusetts, March 11, 1976, reported in the New York Times, March 12, 1976, p. 4.

${ }^{6}$ Henry A. Kissinger. Address made in San Francisco, California, February 3, 1976. U.S. Department of State, Bulletin, Vol. LXXIV, No. 1913 (February 23, 1976), p. 204.

7 "Detentes Supporters Under Fire in the U.S.," New York Times, December 29, 1975, p. 1.

${ }^{8}$ Joseph J. Sisco. Address made in Washington, D.C. May 4, 1976. U.S. Department of State, Bulletin, Vol. LXXII, No. 1878 (May 26, 1975), p. 681 .

${ }^{9}$ Kenneth Rush. Address made in Greenville, Tennessee, May 26, 1974. Ibid., Vol. LXX, No. 1825 (June 17, 1974), p. 652.

10 Henry A. Kissinger. Address made in Los Angeles, California, January 24, 1975. Ibid., Vo1. LXXII, No. 1860 (February 17, 1975), p. 198.

11 Henry A. Kissinger. Address in Birmingham, Alabama, August 14, 1975. Ibid., Vo1. LXXII, No. 1890 (September 15, 1975), p. 392.

12 "Report of the Central Committee of the C.P.S.U., Pravda, February 25, 1976, pp. 3-4.

$$
13
$$

Ibid., p. 3

14 Ibid., p. 4

${ }^{15}$ Moscow Domestic Service, in Russian, May 29, 1977, Foreign Broadcast Information Service, Daily Report: Soviet Union, Vol. III, N0. 104 (May 31, 1977), pp. A2-A3.

16 Mikhail Mikhaylov, "International Observers' Roundtable," Moscow International Service, June 19, 1977, F.B.I.S., Daily Report: Soviet Union, Vol. III, No. 118, (June 20, 1977), P. A2. 
17L.I. Brezhnev, Pravda, May 30, 1977, p. 1.

${ }^{18}$ An entire chapter will be devoted below exclusively to an historical analysis of the transformation of detente politics from 1917 to the present. In this analysis the contemporary era of detente will be seen as having its inception with the Nixon-Brezhnev summit of May 22-29,
1972 in Moscow.

${ }^{19}$ Yuri Chernov, Pravda, June 15, 1972, p. 5.

20 Ibid.

${ }^{21}$ Georgi Arbatov, Izvestia, June 22, 1972, p. 3.

22 Ibid.

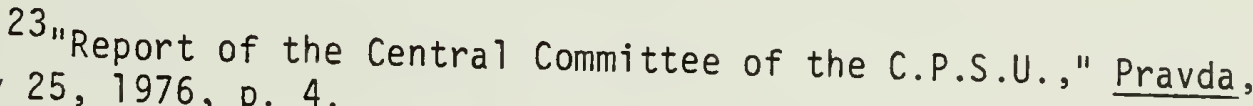
February 25, 1976, p. 4.

${ }^{24}$ Georgi Arbatov, Pravda, April 2, 1976, p. 4.

${ }^{25}$ Radio Moscow, May 27, 1977, F.B.I.S. Daily Report: Soviet Union, Vol. III, No. 105 (June 1, 1977), P. B1.

${ }^{26}$ Zbigniew Brzezinski, "How the Cold War Was Played," Foreign Affairs, Vol. 51, No. 1 (October, 1972), p. 207.

27 Ibid., p. 209.

28 U.S. Foreign Policy for the 1970's: Shaping A Durable Peace.

A Report to the Congress by Richard Nixon, President of the United States, May 3, 1973 (Washington: U.S. Government Printing Office), p. 26.

29" The Moscow Summit: New Opportunities in U.S.-Soviet

Relations," Address by President Nixon before a joint session of the Congress, June 1, 1972. United States Foreign Policy, 1972: A Report of the Secretary of State (Washington: U.S. Government Printing Office, Apri1, 1973), P. 613.

30 Ibid.

${ }^{31}$ Kenneth Rush. Address delivered in New York City, February 15, 1974. U.S. Department of State, Bulletin, Vol. LXX, No. 1811 (March 11, 1974), p. 239.

32 Gerald R. Ford, "State of the Union Address," January 22, 1977. U.S. Department of State, Bulletin, Vol. LXXVI, No. 1963 (February 7, 1977), p. 98.

${ }^{33}$ Gerald R. Ford. Interview on N.B.C. television, January 3, 1976. U.S. Department of State, Bulletin, Vol. LXXIV, No. 1909 (January 26, 1976), p. 102. 
${ }^{34}$ Roger E. Kanet and Donna Bahry, "Soviet Policy in East

Europe," Current History, Vol. 69, No. 409 (October, 1975), p. 154.

35

Henry A. Kissinger. Address delivered in Birmingham,

Alabama, August 14, 1975. U.S. Department of State: Bulletin, Vol. LXXIII, No. 1890 (September 15, 1975), p. 392.

36 "Letter from Alexander Solzhenitsyn Regarding Invitation to Appear Before Joint Subcommittee Hearings on Detente and Human Rights." U.S. Congress, House, Committee on Foreign Affairs, Detente, Hearings, before the subcommittee on Europe of the Committee on Foreign Affairs, House of Representatives, 93rd Cong., 2nd session, 1974, p. 556.

37 "Statement of Klaus Mehnert," Ibid., p. 280.

38 "Statement of David Zilberman," Ibid., p. 290.

39 "Statement of Lev. E. Dobriansky," Ibid., p. 362.

40 Henry A. Kissinger. Address delivered in San Francisco, California, February 3, 1976. U.S. Department of State, Bulletin, Vol. LXXIV, No. 1913 (February 23, 1976), p. 201.

${ }^{41}$ Henry A. Kissinger. Testimony before the U.S. Senate Committee on Foreign Relations, March 16, 1976. Ibid., Vol. LXXIV, No. 1920 (Apri1 12, 1976), p. 486.

${ }^{42}$ Winston Lord. Address delivered in Washington, D.C., November 11, 1976. Ibid., Vol. LXXV, No. 1954 (December 6, 1976), p. 681.

43" Report of the Central Committee of the C.P.S.U.," Pravda, February 25, 1976, p. 4.

${ }^{44}$ Henry A. Kissinger. Address delivered in San Francisco, California, February 3, 1976. U.S. Department of State, Bulletin, Vol. LXXIV, No. 1913 (February 23, 1976), p. 202.

45 "Statement of Marshal1 D. Shulman," U.S. Congress, Detente, Hearings, p. 31 .

${ }^{46}$ Arthur A. Hartman. Address delivered in Houston, Texas, March 4, 1976. U.S. Department of State, Bulletin, Vol. LXXIV, No. 1919 (April 5, 1976), p. 434.

${ }^{47}$ Georgi Arbatov, Pravda, Apri1 2, 1976, p. 4.

${ }^{48}$ Commentator, Pravda, January 1, 1976, p. 4.

${ }^{49}$ Leonid Brezhnev, "In the Name of Peace, Security and Cooperation," Pravda, August 1, 1975, p. 1. Translated in the Current Digest of the Soviet Press (C.D.S.P.) Vol. XXVII, No. 31 (August 27, 1975), p. 13 . 
${ }^{50}$ Constitution of the Union of Soviet Socialist Republics, (Draft) I. Principles Underlying the Social, Political and Economic Structure, Chapter 4, Article 28, Pravda, June 4, 1977, p. 1.

${ }^{51}$ Editorial, "Peace As A Law, Peace As A Deed," Novoye Vremya, June 10,1977, p. 1.

52 Editorial, "Reliable Stronghold of Peace," Pravda,
1977, p. 1. June 14,1977, p. 1 .

53 "Statement of Fred Warner Neal," U.S. Congress, Detente, Hearings, p. 16.

54 "Letter from Alexander Solzhenitsyn," Ibid., p. 557.

55 Arthur A. Hartman. Address delivered in Houston, Texas, March 4, 1976. U.S. Department of State, Bulletin, Vol. LXXIV, No. 1919 (April 5, 1976), p. 433 . 56 Henry A. Kissinger. Address delivered before the 37 st United
(O) Nations General Assembly, New York, September 30, 1976. Ibid., Vol. LXXV, No. 1948 (October 25, 1976), p. 499.

57 Richard M. Nixon. Toast given at dinner reception in Moscow, May 22, 1972, United States Foreign Policy, 1972, p. 592.

${ }^{58}$ Richard M. Nixon. Address delivered to joint session of Congress, June 1, 1972, Ibid., p. 613.

${ }^{59}$ Zbigniew Brzezinski. News conference in Washington, D.C., Apri1 1, 1977. U.S. Department of State, Bulletin, Vol. LXXVI, No. 1974 (April 25, 1977), p. 477.

60 Jimmy Carter, "Peace, Arms Control, World Economic Progress, Human Rights: Basic Priorities of U.S. Foreign Policy." Address delivered to the United Nations General Assembly, March 17, 1977. Ibid., Vol. LXXVI, No. 1972 (April 11, 1977), p. 331.

61 Walter Mondale. Address to the North Atlantic Council, Brussels, January 24, 1977. Ibid., Vol. LXXVI, No. 1967 (March 7, 1977), p. 183.

${ }^{62}$ Henry A. Kissinger. Testimony before U.S. Senate Committee on Finance, March 7, 1974. Ibid., Vo1. LXX, No. 1814 (Apri7 1, 1974), p. 323.

63 Leonid Brezhnev. Interview with chief editor of Japanese newspaper, ASAHI, F.B.I.S., Daily Report: Soviet Union, Vol. III, No. 116 (June 16, 1977), p. R7. 
THE HISTORICAL CONTEXT OF DETENTE

It has become quite fashionable for political commentators to write the final obituaries for detente. Detente, in this view, was born in Moscow in 1972 and died in Afghanistan in 1980. Detente may or may not have served its basic purpose, but in any event, it is now dead; the victim of a Soviet act of aggression and a firm American response to that act.

Such an argument appears to contain two basic flaws, one of which will be the focus of this present chapter. The first concern is that there is evidence to suggest that detente is not dead. It is, to be sure, being re-evaluated by the United States and may, in fact, be diminished in the American view. However, it is not a forsaken policy in the Soviet view. In fact, detente from the Soviet perspective, as will be shown below, is being pursued with a good deal of enthusiasm. The second concern addresses the birth of detente. Specifically, the claim that detente is a policy that began in 1972 at the Moscow summit is one that deserves carefur scrutiny.

As was mentioned above, the concept of Soviet-American detente has generated no small amount of confusion. Much of this confusion rests with the fact that there is no consensus regarding the very meaning of detente. Thus, as we have seen, both the U.S. and the U.S.S.R., while pursuing objectives contrary to the interests of the other, simultaneously acclaim the virtues of a detente policy that governs their relations 
The specific area of concern that has caused much of the present misunderstanding relates to the role that history has played in the formulation of detente. In short, this problem is manifested by the tendency of many observers to perceive detente through a perceptual lens that virtualiy excludes an assessment of the historical context in which detente has been conducted. Detente, in this view, is seen as a novel policy that was designed by the Nixon and Brezhnev regimes. Detente has been seen as their attempt to find a new and unprecedented answer to the formidable dilema of managing Soviet-American affairs, and as an alternative to the exacerbation of tensions and mutual hostility that had marked their previous relations.

However, there is evidence to show that detente is a process with which Soviet and American statesmen have been grappling for some time, and which had been a variable in U.S.-Soviet relations for a full half century before Richard Nixon set foot on Soviet soil. Detente, in this view, was not born with the signing of the Moscow Declaration of Principles as many in Washington would have us believe. Rather, it can be argued that it was conceived and put into practice as a viable tactic and strategy in the earliest days of Soviet power. As such, the phenomenon of detente has deep historical roots that should be understood if its present manifestation as the most significant aspect of contemporary interstate affairs is to be understood.

It could be quite misleading to view detente as the brainchild of the present Soviet regime, or as some totally unheard of concoction of Soviet propagandists who arduously labored to devise a politically and ideologically proper means of addressing the problem of handling Soviet-American relations in the 1970's. It would seem to be equally 
misleading to view detente as the righteous and virtuous policy devised by American statesmen as the only sane and sensible means of conducting relations with Moscow without threatening the destruction of civilization by inviting a cataclysmic thermonuclear holocaust. To perceive detente in either of these fashions would be to ignore much of the history of detente.

Detente in respect to U.S.-Soviet relations is a by-product of the unique tendencies that characterized the formulation of the tentative, and often hostile, relations between two nations espousing antithetical and totally irreconcilable ideologies and world views. Moreover, it was, as the evidence below will show, a willful and carefully designed policy of one system of government, whose avowed aim and primary purpose was the complete overthrow and final destruction of the opposing socioeconomic system. It was, in this view, an attempt to effect a means of conducting international affairs in a manner that seemed most conducive to realizing that system's ultimate goals.

The process of detente, whether or not it has been vigorously adhered to by the nations of world capitalism-imperialism, has been nurtured and reared throughout the history of Soviet-American relations by the Soviet Union. Detente has progressed to the point that we are now witnessing its final fruition as the legally accepted norm by which both sides have agreed to conduct their mutual affairs. In this manner the present variation of detente can be seen as representing a victory of sorts for the Soviet Union. For fifty years the ruling hierarchy in Moscow, and the most noted communist theoreticians in the world, had been ardently proclaiming the correctness and objective necessity for the policy of detente as the only rational means for conducting relations 
among states with different social systerns. In the face of this unrelenting propaganda fusillade directed at the righteousness of the "peaceful" objectives of the Soviet Union, the Western world, and most notably the United States, was unimpressed. In fact, the United States tended to ignore the concept and avoided any outward manifestation of tacit approval or adherence to this policy. The present Soviet regime can rejoice to some extent in the fact that their program, conceived and developed in the Leninist years, and meticulously bred to its full maturation in the ensuing half century, has finally been accorded complete and total recognition by the West, the very existence of which it was originally created to destroy. When Richard Nixon and Leonid Brezhnev signed the "Declaration of Basic Principles" in Moscow in May of 1972 and proceeded from the "common determination" that there "is no alternative to conducting their mutual relations on the basis of peaceful coexistence," they did not create the process of detente. Instead, as the ensuing chapters will demonstrate, they merely accorded official recognition and formal acceptance to a phenomenon of international relations that had been a vital and central part of U.S.-Soviet relations for more than fifty years.

The fact that the Soviet regime remained fully committed to detente throughout such a long period of time, which witnessed marked fluctuations from eras of conciliation to eras of animosity between Moscow and Washington, is strong testimony to the tremendous degree of importance that the Kremlin has attached to this concept. It is important in this light to interject two caveats into the historical and causal links from detente under Lenin to detente under the present Soviet leadership.

The first of these considerations has to do with the revisions 
which detente has undergone during its lifetime. To unequivocally assert that detente politics of 1972 or 1980 and detente politics of 1918 or 1921 are totally and completely synonymous concepts, without exhibiting the slightest variations in theory and practice, would be to oversimplify. It will be demonstrated that detente, as a functioning process dominating the conduct of Soviet-American affairs, has been able to withstand the tests of time by virtue of its ability to adapt and correspond to the ebb and flow of the volatile shifts in the atmosphere of international relations. At any given time the process of detente, viewed amidst the background of the existing international environment, may be quite accurately perceived as more or less durable, intense, and pragmatic than at another given time. Although detente transcends the usual concerns of short-term international politics, it must be borne in mind that the residual effects of these particular actions and events, and the political climate they foster, have determined both the strength of detente as well as the vigor and enthusiasm with which it is pursued. Crises, unfavorable political incidents, wars, alliances, and political leadership changes have all, at one time or another, proven to be prime determining factors in the creation of periods in which detente was mildly pursued amidst an air of increased tensions and contravening political objectives. At the same time, these variables have fostered eras in which the limited goals of both sides were coincidental, thus producing a period of strong coexistence between the two as each strove to jointly and harmoniously effect common ends.

Hence, it is not surprising that detente, as manifested during the Soviet-American alliance of World War II, has been described as a period, albeit of extremely short duration, in which both nations in 
their united quest to crush the menace of Nazi Germany, reduced tensions and animosities to very low levels. This upsurge in the fortunes of Soviet-American coexistence, of course, stood in marked contrast to the preceding inter-war years, when, although peaceful coexistence was inherent in the foreign policy line of the Soviet Union, relations were continually strained. Here, both parties, preoccupied with overriding domestic difficulties and pursuing a foreign policy stance with objectives inimical to the interests of the other, found little common ground for mutuai understanding.

Similarly the high level of cooperation and conciliation that was witnessed in the struggle against Hitler experienced a drastic and predictable downturn in the immediate postwar years as the Soviet Union and the United States moved to the Cold War. The Cold War years, replete with the tensions, threats, confrontation, saber-rattling, and short-lived "spirits" of Geneva, Camp David, and Glassboro, would in their turn, give way to the antithesis of improved relations and negotiations that we are experiencing today. The present variation of detente is itself undergoing the same oscillations and pendular shifts of its predecessors. The October Mideast War, the crisis in Angola, Afghanistan and the strategic arms impasse, have all contributed to the flux and reflux we are now witnessing between high levels of vitality for detente and the lowest stratum of Cold War-like animosity.

It is important to remember that detente, notwithstanding the above-mentioned fluctuations in U.S.-Soviet relations, permeated the activity of the U.S. and the U.S.S.R. from 1918 to the present. Detente may well have been weak or strong or passive or active during any one year or period of years that spanned more than a half century of 
Soviet-American relations. Yet, the evidence suggests that detente did exist throughout this period and provided perhaps the one common thread that has marked Soviet foreign policy from its earliest years to contemporary times with respect to its relations with the United States. As will be seen below the form that detente took during this period changed from a defensive ploy by Lenin and Starin ("peacefur cohabitation"), to an offensive strategy by Khrushchev ("peaceful coexistence"), to an aggressive offensive strategy by Brezhnev ("detente" "relaxation, or reduction of tension").

The Soviet use of the terminology involved in the subject of detente deserves some attention in that it both provides an accurate means for measuring Soviet motives and underscores a central theme of this dissertation. In the first place, it should be noted, as seen above, that this writer employs the term detente to describe the Soviet version of a policy from Lenin to Brezhnev. This is being done for two (2) principal reasons. First, the term detente has become the accepted word, especiality in the West, that is used to describe the relationship between the nations of the East and West in general, and the United States and the Soviet Union in particular. Secondly, as will be argued below, the Soviet Union in implementing a contemporary policy of detente has maintained the most important features of the original detente policy of Lenin.

None of this is to say that the Soviet Union has consistently utilized the word detente to describe any particular era of international relations. In fact, Lenin, Stalin, and Khrushchev appear to have never used the word at a 11 . The usual terminology during the early years of Soviet rule was mirnoe sozhitelstvo (peaceful cohabitation). It will be argued below that this phrase, as an early variation of the detente 
terminology, was used to describe an essentially defensive strategy that sought to gain a breathing spell or a respite in war for the Soviets. In later years, the Soviet Union widely utilized the phrase mirnoe sosushchestovavanie (peaceful coexistence). As will be reasoned below, peaceful coexistence constitutes an offensive Soviet strategy that implies a constant struggle with the West with the objective of assuring favorable conditions for the worldwide victory of socialism. Contemporary Soviet spokesmen often use the term razryadka, or the phrase razryadka napryazhennosti (relaxation or reduction of tension). The term razryadka has almost always been translated in the West to read detente. (Detente is literally defined in Western dictionaries, e.g., Webster's Third New International Dictionary of the English Language Unabridged, rev. ed. (1976), as the reduction or the lessening of tension.) However, detente (razryadka) is used by the Soviet Union to describe a state of reduced tensions (especially, reduced thermonuclear war tensions) in international relations resulting from the observance of the principles of peaceful coexistence. Thus, razryadka would seem to flow from the phrase mirnoe sosushchestovavanie and, in effect, be a component part of the latter. Peaceful coexistence, which the Soviets, in their view, have defined with utmost clarity, then becomes the most important of the three (3) detente-related phrases. Detente, it will be argued below, represents a logical extension by the Brezhnev regime of the Khrushchev policy of peaceful coexistence. It will further be reasoned that Brezhnev, with the establishment of thermonuclear parity, the realignment of world forces in favor of socialism, and other factors felt it necessary to add an image of reduced tension and threats and increased Soviet cooperation and friendliness to the peaceful coexistence formula. It will also be shown that Brezhnev, in 
the implementation of detente, never reduced, and actually strongly reinforced, the primacy of the peaceful coexistence characteristics of intensifying the political, economic, and ideological struggles, of eliminating the international status quo, furthering the expansion of socialism, providing the best conditions for communist construction, and preparing the way for the eventual worldwide victory of socialism.

To separate detente from peaceful coexistence, or to ignore the relation between the two, can, quite naturally, cause confusion. Henry Kissinger, in discussing detente, was using a term that would appear to be very pleasant and non-threatening to an American audience. In the face of a thermonuclear capacity that could destroy a 17 of mankind, as Kissinger often claimed, a detente, or relaxation of tensions, would seem to be a most appropriate policy. However, it will be argued below that the Soviet Union, by not using detente in isolation from peaceful coexistence has a far different connotation of the same term.

One need also be mindful of the fact that a number of tactical variations have been implanted in the Soviet strategy of detente over the years. These changes have further differentiated present-day detente from the process that was established by Lenin. It will be argued below that the Soviet ruling hierarchy has revised and altered basic components of detente politics to better suit the modern world of thermonuclear technology. Yet, while the U.S.S.R. has interjected basic strategic alterations in the tactical means of the detente process, the final ends for which this strategy was initially created have not been changed. Throughout the entire history of U.S.-Soviet detente, the primary rationale for the inception of detente politics, the creation of advantageous conditions for the strengthening of communism and the 
dissemination of socialist principles to the direct disadvantage and eventful demise of the capitalist-imperialist system, has not been eliminated.

The second consideration has to do with the unprecedented significance that one should properly attach to the present era of detente. It has been noted earlier that this writer is committed to the view that the contemporary U.S.-Soviet detente is the most important facet of international relations of this or any other age. However, if detente, as seen today, is a direct descendant and historical maturation of a fifty year old policy with deep and lasting historical roots, then it is important to reiterate why the latest variation of this process is significantly more important than any of its earlier stages.

Detente, as we have correctly been told, has confronted the United States with a challenge unprecedented in its history. Yet, much of this reasoning is based on the assumption that the challenge with which we are faced is primarily concerned with the prevention of nuclear war and its almost certain devastation of modern civilization.

However, the relative significance of contemporary detente can also be seen as a direct result of the strategic parity that now exists between the two superpowers. Throughout all previous stages of detente the process was almost always conducted between two vastly unequal parties. With the United States enjoying an inordinate military superiority, the Soviet Union, in the initial phases of detente, had to set certain limits on acceptable expansionist policies while struggling to overcome the awesome gap in the relative military prowess of the two adversaries. Even after emerging from the second world war as a bona fide military power, the U.S.S.R. constantly had to be mindful of the superior military 
might of its chief rival. While asserting itself more aggressively in the world arena, the Soviet Union could never fully challenge the United States until a drastic altering of the strategic balance could be realized. In the early 1960's the U.S.S.R. purported to have achieved such a balance. Consequently, Moscow embarked on a fairly aggressive, if not somewhat reckless, course of action. When this alleged equality in strategic weaponry was shown to be a sham, however, much of the lifeblood of Soviet aggressiveness had been sapped, and the Kremlin again became preoccupied with erasing the American nuclear advantage.

The present Soviet leadership is not confronted with such an overwhelming dilemma. By most accepted standards the U.S.S.R. has achieved strategic parity, and can therefore act in the world arena as a co-equal, with the United States vis-a-vis the relative military capabilities of each side. While this balance of power quite naturally raises the specter of nuclear war, an important asset from the Soviet perspective, is the increased flexibility and risk-taking potential that it affords the Kremlin.

Thus, during the present era of detente the Soviet Union has shown an increased willingness to embark on a course of action aimed at implementing incremental and gradual changes in the East-West equation to the direct detriment of the United States. While these alterations in the framework of world politics, which are advantageous for Soviet purposes, are being realized, the U.S.S.R. for its part can rattle the saber of nuclear confrontation as a tempering and moderating factor to any direct American response. Hence, the awesome destructive power of thermonuclear weapons, and the effective equivalence of the world's two 
nuclear superpowers have served as factors in both the level of aggressiveness of any given policy objective and in the militancy of its elicited response.

We in the West have shown a willingness to give our tacit approval to such a formula. American policy makers have exhibited a tendency to place strategic arms control and reduced thermonuclear hostility on such a high plateau of priorities that any "minor" area of concern could be sacrificed on this altar of peace in the nuclear age. Hence, in the case of Angola, in the face of serious encroachments by the Soviet Union and its Cuban ally in that nation, the United States pursued a policy that, in effect, stated that this area was not strategically important enough to warrant a response that would either threaten the ongoing strategic arms negotiations or invite a direct confrontation between Moscow and Washington. Such a reaction on the part of the American government might well serve to foster an era in which the fear of a nuclear exchange can act as the catalyst for the further dissemination of Soviet influence, as outlined in their program of detente. In the past detente provided the Soviet Union with a breathing spel1, a respite in war as Lenin described it, whereby the young Soviet state could concentrate its efforts on strengthening its power and overcoming the massive gap in the scientific-technological, and military capabilities, vis-a-vis the West. All of this was done in preparation for the inevitable and fatalistic confrontation with the capitalist powers.

The present era of detente, pursued in the environment of nuclear parity, may well provide the fulcrum, without the necessity of a direct catastrophic confrontation, by which the ultimate objectives of Soviet ideology may be more easily and gradually realized. 
The history of Soviet-American relations, with the notable exception of the mercurial period immediately following the Bolshevik revolution, can be seen as the history of detente. Yet, it is obvious that such a view is not uniformly held by all observers. Detente is still often referred to as a new or unique phenomenon engendered by the needs of the international political environment of the 1970's. In the official report of the Secretary of State for 1972, for example, it is noted that the Moscow summit, highlighted by the "signing of a declaration embodying tweive basic principles of relations," had "helped to usher in the beginning of a new era in U.S.-Soviet relations." 1 Such a reference to a "new" era of U.S.-Soviet relations was characteristic of the general theme espoused by the American government in the days immediately following the Moscow summit. In his address to a joint session of Congress upon his return from the Soviet Union, Richard Nixon fostered the same view of detente as a unique and unprecedented process:

The foundation has been laid for a new relationship between the two most powerful nations in the world. Now it is up to us, to all of us here in this chamber, to all of us across America, to join with other nations in building a new house upon that foundation, one that can be a home for the hopes of mankind and a shelter against the storms of conflict. ${ }^{2}$

Much of the substance of this view can be explained by the need for political bombast on the part of the president, and by the general state of euphoria that permeated the immediate post-summit days. Yet, it is still clear that detente was being defined as a process born of the contemporary political milieu and, as such, constituted an unheralded phenomenon. In his report to the Congress nearly a year after the conclusion of the summit, Nixon asserted that this new era should be a11-inclusive since, "it is not a question of whether certain elements should be separable, or conditional, but whether we wish the entire process of a 
broadly based new relationship with the Soviet Union to unfold." 3 More importantly, the former president inexorably linked this "broadly based new relationship" to the central themes elaborated upon in the "Declaration of Basic Principles." In describing the Moscow Declaration, Nixon accorded it the following place of importance:

This far reaching step placed all our other efforts on a broader foundation. A new relationship would require new attitudes and aspirations. It was appropriate that this change These principles are a guide for future action, not a
commentary on the past. 4 .

It must be remembered that the "Declaration of Basic Principles" entails the primary elements of detente. Thus, when Nixon claims that the declaration is representative of "new attitudes and aspiration," he is only representing, at best, one-half of the bi-lateral equation; that of the American perspective. The doctrine of detente, it is argued, was a symbol of Soviet attitudes and aspirations long before the term became a fashionable addition to the American political lexicon.

In much the same manner, Arthur Hartman, the then Assistant Secretary of State for European Affairs, made detente synonymous with a "new" period of U.S.-Soviet relations:

I am convinced that it is important for us to understand the circumstances that have led to the beginning of this new period in relations between the United States and the Soviet Union and to ask ourselves hard questions about the meaning and durability of these relationships that we sum up in the word "detente." 5

Such a representation of detente can lend an air of misapprehension to the policy as we have come to know it today. To ignore the historical roots of detente and perceive it as something new, might be to ignore much of the underlying Soviet motivation for this process that the Kremlin has manifested for more than fifty years. 
It is interesting, in this light to ask just what the "newness" of this relationship actually is. There is no doubt that the U.S. government, through its authoritative spokesmen, is referring to the new period of thermonuclear technology. Hence, in a lengthy address, devoted solely to an exposition on the detente posture between Moscow and Washington, Henry Kissinger elaborated on the unique feature of contemporary international life:

There is one central fact that distinguishes our era from a 11 previous historical periods; the existence of enormously destructive weapons that can span unlimited distances almost instantaneously. No part of the globe is beyond reach. No part of the globe would be spared the effects of a general nuclear exchange. 6

There is certainly no question that the emergence of vast nuclear capabilities has added an unprecedented dimension to the conduct of international affairs. Yet, this does not necessarily imply that the process of detente, pursued within this environment, represents a new or unique formula in itself. What is new, in this writer's view, is the aforementioned strategic parity that has transformed the latest variation of detente into a significant facet of contemporary world politics.

Throughout Soviet history the Kremlin leaders have constantly asserted that their pursuit of peaceful coexistence represented a direct continuation and fulfillment of an ideological doctrine established by Lenin. In order to leave no room for misunderstanding, the Soviet press, on the very day of the signing of the "Declaration of Basic Principles," implacably linked the present process of detente with that which was established by Lenin:

The great Lenin put forward and fully substantiated the principle of peaceful coexistence among states with different social systems. In the very first hours of Soviet power, while addressing the Second Congress of Soviets, he said: "We reject all clauses concerning robberies and violence, but we shall 
cordially accept all the clauses containing good neighbor conditions and economic agreements -- these we cannot
reject.

.... In consistently implementing the Leninist policy of peaceful coexistence, the C.P.S.U. is not retreating a single step from its ideological principles -- the firm principles of Marxism-Leninism and proletarian internationalism.7

With Richard Nixon still in Moscow, about to give his formal approval to the principles of detente, the Soviet hierarchy left no doubt that the American president was extending diplomatic recognition to a Leninist policy that the Kremlin was faithfully and diligently implementing:

Back in the early days of the Soviet state, its founder, V.I. Lenin, substantiated the objective necessity and possibility of the peaceful coexistence of countries with different social systems. Today, as before, the Soviet Union is ready to develop and deepen relations of businesslike cooperation and mutually advantageous ties with states of the other social

Such a perspective, while exhibiting a greater sense of historical accuracy than the aforementioned American view, is still imbued with a number of misleading tenets. The Soviet perception of detente, although much closer to the truth by virtue of its recognition of its historical context, still posits some very convenient lapses of memory and indulges in a bit of historical revisionism, something not altogether foreign to Soviet propagandists. There is evidence to show that the present variation of detente differs in fundamental ways from the theory as established by Lenin.

In the first place, at the time of the Second Congress of Soviets the policy of peaceful coexistence, despite the contrary claims of contemporary Soviet spokesmen, not only did not exist but represented the antithesis of the Leninist view in respect to relations with the capitalist world. The first months of Soviet-American relations, as will be discussed 
in detail below, were not characterized by any Leninist desire to co-habitate the globe with the enemies of socialism. Rather, it was an era noted for the intransigent view of Lenin pertaining to his belief that the immediate overthrow of the opposing system should be implemented. Detente should not be seen as a process created immediately after the Bolshevik seizure of control. It could, more accurately, be viewed as a strategic concept that was fully developed by Lenin only after the Soviet leader, confronted with the failure of the socialist revolution in Germany, realized that the primary Soviet objectives could not be achieved without the breathing spell that coexistence would provide.

Secondly, the present variation of detente differs fundamentally from the Leninist conception of the doctrine in relation to the emphasis, or lack thereof, which is attached to the issue of war and its inevitability and necessity. The basic difference in this respect rests with the fact that the present concept, especially after the 20th C.P.S.U. Party Congress of 1956, constitutes a strategic theory that denies the necessity of waging total war between the nations of socialism and capitalism (although the continuing possibility of such a conflict is not ignored). The Leninist concept, on the other hand, gave priority to the objective necessity and inevitable eventuality of a final Armageddon between the two systems. In this manner, the surviving system, which historical objectivity dictated would be the Soviet state, would transform the world by implanting its way of life on the ruins of the vanquished.

The third basic alteration has to do with the nature of detente as a temporary or perpetual foreign policy stance of the U.S.S.R. The present leadership, it will be argued, has made detente the primary and 
fundamental guideline to which all aspects of Soviet foreign policy are to be subordinated. As such, the concept is permanent in essence, since as a mode of conducting relations with different social systems, it will only cease to function when there is no opposing system with which to relate; i.e., when the complete and final victory of socialism and the total defeat of capitalism have been realized. Lenin, however, clearly perceived detente as a strategy that was transient in nature, as it was designed as a response to a specific and limited situation at a particular time. When, in the Leninist view, the Soviet state had strengthened itself sufficiently during the respite of detente, the policy would be discarded and the two systems would engage in their life and death struggle.

The present Soviet contention that detente constitutes a direct continuation of Leninist policies, notwithstanding the obvious differences that have manifested themselves over the years, is a viewpoint that still possesses more truth than fallacy. In fact, it may be safe to assume that Lenin, a most resolute pragmatist and a strategist always mindful of the need to alter or compromise principles and theoretical beliefs, might very well approve of the strategy of detente politics as practiced by the present Soviet regime. The current manifestation of detente has not abandoned the basic Leninist ideological tenet of altering the world in the communist order. As such, it can be seen as a strategic concept adhering to the behests of the founder of the Soviet state.

It is important to ask ourselves now, in just what manner we have arrived at the present epoch of Soviet-American detente. How has this policy evolved and matured over the years to the point that we are now witnessing its fruition as the accepted form of governing the behavior 
between the world's two nuclear superpowers? The answers to these questions can be ascertained by an elaborate and detajled examination of the history of detente as a concept of managing East-West, and more specifically, U.S.-Soviet relations.

The ensuing chapters will therefore, serve as an inquiry, that will focus on an historical analys is of the process of detente from 1918 to the present. 
lUnited States Foreign Policy, 1972: A Report of the Secre-
State (Washington: U.S. Government Printing Office, April,
pp. 309-310. $\frac{\text { tary of state (Wash }}{1973 \text { ), pp. 309-310. }}$

2"The Moscow Summit: New Opportunities in U.S.-Soviet Relations." Address by Richard Nixon before a joint session of the Congress, June 1, 1972. Ibid., p. 611.

${ }^{3}$ U.S. Foreign Policy for the 1970's: Shaping a Durable Peace. A Report to the Congress by Richard Nixon, May 3, 1973 (Washington: U.S. Government Printing Office), p. 35.

${ }^{4}$ Ibid., p. 37.

${ }^{5}$ Arthur A. Hartman. Testimony before the Subcommittee on Europe of the House Committee on Foreign Affairs, May 15, 1974. U.S. Department of State, Bulletin, Vol. LXX, No. 1823 (June 23, 1974),
p. 597 .

${ }^{6}$ Henry A. Kissinger. Address made in San Francisco, California, February 3, 1976. Ibid., LXXIV, No. 1913 (February 3, 1976), p. 206. p. 1 .

7 "For the Benefit of Peace and Security." Pravda, May 29, 1972,

${ }^{8}$ N. Podgorny, Pravda, May 23, 1972, p. 2. 


\section{THE LENINIST PERCEPTION AND}

\section{APPLICATION OF DETENTE}

The political philosophy of V.I. Lenin is a very complicated subject. Lenin not only revised a good deal of Marxism, but added a prolific body of theoretical literature of his own. It can be argued that the combination of the two, or Marxism-Leninism in the Soviet vernacular, formed the basis of the ideological content of detente. For all intents and purposes, however, detente bears the distinct imprimatur of Lenin, who was faced with the formidable challenge of making a revolutionary theory work in the face of a hostile world.

In order to fully understand the intricate complexities that dictated the necessity for Lenin's formulation of detente, one should subject two important variables to an in-depth examination; 1.) the tumultuous historical setting in which the process was born, and 2.) the fluctuating characteristics of Leninist ideology which, in response to this particular historical environment, provided both the rationale and justification for a strategy of action based on reducing tensions with the West. Primary emphasis will be given in this chapter to the adaptive qualities of Leninist ideology that allowed for the creation of detente.

\section{The Historical Setting}

One is hard pressed to depict accurately in words the chaos and turmoil that accompanied the fall of the Czarist autocracy and the eventual 
seizure of power by Lenin and his Bolshevik cohorts. The holocaust of World War I and the concomitant political, social, and economic disarray engendered by that conflict had all but reduced the Russia of 1917 to a prostrate nation. The military situation was one of complete turmoil. The disillusioned Russian army, having suffered intolerable losses of human life, became a disorganized and bedraggled fighting force that could offer little, if any, resistance to the crushing enemy onslaught. Internally, the turbulent storm of discontent forecast a far more onerous turn of events for the existing government. With the near complete breakdown of governmental control, the destruction of communications and transportation, and widespread problems of famine, disease, and social upheaval, Russia in 1917, it can be argued, represented one of the most complete cases of turbulence and social collapse ever suffered by a modern government.

This situation was further aggravated by the existence of a number of diverse revolutionary political parties. While often working towards self-exclusive ends and engaging in bitter and violent conflicts among themselves, these forces managed to manipulate the frantic convulsions of wartime Russia and the disillusionment of the masses into an effective revolution that destroyed the czarist monarchy. However, the fall of Czarism and the ensuing reigns of the Provisional Governments, with their weak and ineffective coalitions of irreconcilable individuals and parties, failed to stem the tide of revolutionary fervor and agitation that had swept the country. The new government also decided to continue Russian participation in the war. In so doing, the Provisional Government sowed the seeds of its own destruction and provided the catalyst for the metamorphic transformation of power into the hands of a relatively small 
band of conspiratorial revolutionaries who, to this day, have not relinquished their control.

The governments of the West, and most notably the United States, apparently possessed little understanding of the complicated and diversified events that were unfolding in this traumatic drama in Russia. Guided by a perspective that was dictated by the exigencies of the First World War, American politicians and policy makers had little time to concern themselves with the bizarre and puzzling series of revolutions and ensuing governments on Russian soil, except as they pertained to the pursuance of the war itself. As though no drastic alteration of the basic structure of Russian power had ever occurred the United States seemed to look upon the new regime as a manifestation of Czarist Russia without the person of the czar.

Hence, the United States wasted little time in extending formal diplomatic recognition to the new government based on the hope that "the cordial relations existing between the two countries continue" and "prove mutually satisfactory and beneficial." " Likewise, President Wilson, amidst the background of the chaos and havoc of post-Czarist Russia, expressed both the "deep friendship of the American people for the people of Russia," and his hope that they would find "the best and most practical means of cooperation between the two peoples in carrying the present struggle for the freedom of all peoples to a successful consummation." 2 This policy seemingly involved a continuation of policies pursued with Nicholas II. It also apparently ignored the horrendous series of misfortunes that the Kerensky government was experiencing. The catastrophic military losses suffered in the new offensive, the further spread of famine and governmental collapse, the armed uprisings 
and revolts, and the increased disenchantment of the masses, all combined to render the Provisional Government useless and interjected a new and volatile variable into the already advanced state of mass confusion that existed on Russian soil.

This new factor, of course, was the formidable rise of the Bolshevik Party which, through its irrepressible and tenacious leader V.I. Lenin, called for an immediate and violent revolution, not only in Russia, but throughout the entire capitalist world. This new Bolshevik phenomenon, as will be explained below, would confront the United States with a heretofore unseen foreign policy dilemma. Guided by the dictates of Leninist ideology, the new Soviet government would add a complicated, and often misunderstood, variable to the overall pursuit of American objectives. The Bolshevik Party first irritated the United States by refusing to continue military participation in the war. The Soviets then added insult to injury, and no doubt confused a good many people, by asserting that their revolution would not be complete until it had successfully crumbled the pillars of the American government itself.

The means by which Lenin was able to seize power and maintain it during these turbulent years is a fascinating historical pnenomenon in its own right. The main focus of this chapter, however, is on the flexible aspects of Leninist ideology that allowed for the formulation of detente.

\section{Leninist Ideological Revisionism: The Foundation of Detente}

By carefully analyzing Leninist ideology, in regard to its flexible and adaptive qualities, three areas of detente will be more clearly understood. First, the necessity of creating detente, from Lenin's perspective, will be demonstrated. Secondly, the changing 
characteristics of detente, that became obvious during Lenin's lifetime, will be highlighted. These two characteristics will then shape much of the ideological content of detente that persists to this day.

As will be shown below, Marxist-Leninist ideology has exhibited the ability to be adapted to a format that can conform to many prevailing historical or political situations. This is not to say that MarxistLeninist ideology has been totally perverted, or that its basic fundamentals have been eliminated. At the same time, however, it cannot be seen as an overall inflexible or ironclad dogma with no room for interpretation and, in some cases, revision. The present Soviet leadership, as wilt be shown in the ensuing chapter, steadfastly adheres to the most crucial and fundamental principles of the ideology of Marxism-Leninism. Yet, in regard to specific details of action, the ideology in many aspects appears to serve more as a blueprint for acceptable activity than as a prescriptive guide to specific behavior. It can be demonstrated that Lenin opened many of the floodgates of human voluntarism and permitted the interpretation and alteration of ideology. This was seen by Lenin as a means by which he could both seize power in economically backward Russia, and then formulate a foreign policy for a socialist state in the midst of an unreceptive capitalist world.

Marxism, as a reflection of socialist theories originally espoused by Marx and developed by his followers and successors, utilized a set of scientific principles that were based on a commitment to the laws of historical and economic determinism. A socialist revolution, in this sense, would occur first in the most advanced states of Europe. Here, the basic preconditions for a socialist transformation, including a class conscious and exploited proletariat, a state of high capitalist 
productivity, and an advanced level of industrialization, would first be realized. These factors would inevitably lead to the increased misery of the proletarian class and the eventual "dialectical leap" whereby capitalism would pass into the higher form of socialism. Armed uprisings, wars, riots, strikes, revolts, conspiracies, propaganda, and assassinations were of relatively minor importance in this body of thought. White these variables may exist in any era of socialist transformation, they would be subordinated to the more crucial factor of advanced capitalist deveropment.

Lenin adhered to the spirit of these laws of Marxism. In fact, Lenin dismissed any "nonsense" about "Russia, for instance, being able to avoid capitalist development, jump out of capitalism, or skip over it, by some means other than the class struggle on the basis, and within the limits of capitalism." 3 Thus, it would appear to have been incumbent upon Lenin to show that capitalism had indeed become fully developed in Russia in 1917. Earlier, Lenin had made a rather unpersuasive attempt to chart the progress of capitalist development on Russian soil from 1896 to 1898. 4 In 1917, in the face of the lack of the precondition of advanced capitalist development, (e.g., Russia's small proletariat and capitalist class, rural-based economy, etc.), Lenin asserted that "objective conditions show that the war has accelerated the development of capitalism which advanced from capitalism to imperialism, from monopoly to state control. 15

Lenin, however, apparently realized that the development of capitalism in Russia had not reached its fullest proportions as envisioned by the laws of Marxism. It was imperative therefore, for Lenin to inject the hand of human intervention and voluntarism as an alternative to any 
rigid determinism. To this end, Lenin would "bring" the revolution to Russia, and bypass some of the essential economic requirements. This would be done by use of his dedicated corps of clandestine and conspiratorial revolutionaries and propagandists who would serve as contriving agitators in "rousing political discontent among all classes, rousing the sluggards, pushing on the laggards and providing a wealth of material for the development of the political consciousness and political activity of the proletariat." 6 It was a belief of Lenin that the "only serious principle the active workers of our movement can accept is strict secrecy, strict selection of members and the training of professional revolutionaries, "7 who, as he had earlier stated, would "devote to the revolution not only their spare evenings but the whole of their 1ives." 8 The revolution had therefore, been given a push by the Bolshevik Party which was aware of the backwardness of Russia as well as its total lack of socialist revolutionary zeal. They then, would "go among all classes of the people as theoreticians, as propagandists, as agitators, and as organizers," bearing in mind Lenin's behests that "the principal thing is propaganda and agitation among all strata of the people." 9 In this and many other ways, such as his revolutionary alliance with the peasantry which Marx and Engels had denounced as "reactionary," and his belief in the primacy of the need for violent and armed uprisings, Lenin gave his revolution a much-needed touch of pragmatic reality. By so doing, he effectively bypassed some of the more basic teachings of Marxism and brought a socialist transformation of power to an underdeveloped, agrarian-based, and rural country.

The most crucial aspects of the Leninist revision of Marxism, in this writer's view, occurred in the treatment that Lenin accorded the theories of imperialism, war, and the forcible exportation of socialist 
revolutions abroad, all of which played a critical role in the initial formulation of the policy of detente. In much the same manner that contemporary Soviet propagandists justify their "independent elaboration" of Marxist-Leninist ideology, Lenin had little difficulty in explaining the need for updating Marxism in the "era of imperialism." Lenin incessantly criticized those who would "fix for all time the point of view Marx held in a different epoch," as an attempt to use the letter of Marxism against the spirit of Marxism." 10 In this light, Lenin showed the proper relationship of Marxism to the revolutionary struggle in Russia.

We do not by any means look upon the theory of Marx as something final and inviolable; on the contrary, we are convinced that it only laid the cornerstone of the science which Socialists must advance in all directions, if they do not want to lag behind events. We think that the independent elaboration of Marx's theory is especially necessary for Russian Socialists since this theory provides only the general guiding principles which in detail must be applied in England in a manner different from that applied in France, in France in a manner different from that applied in Germany, and in Germany in a manner different from that applied in Russia.1

Lenin, as contemporary Soviet leaders, claimed that "we are Marxists and we take as our basis the Communist Manifesto. "12 However, as he admitted earlier, those "who are in the least acquainted with the actual state of our movement cannot but see that the spread of Marxism was accompanied by a certain lowering of theoretical standards. "13 It can be reasoned that this lowering of theoretical standards and independent elaboration of Marxism provided Lenin with the theoretical basis for formulating the policies that guided Soviet relations with the West; policies that would eventually lead to the strategy of detente. 
The Early Months of U.S.-Soviet Relations

The first official action in the history of Soviet-American relations took place the day after the Bolshevik seizure of power, on November 8, 1917. At that time the Second A17-Russian Congress of Soviets issued the "Decree on Peace." The new Soviet government, disavowing any allegiance to the Czarist wartime alliance, called for all belligerent parties to submit to "the immediate opening of negotiations for a just and democratic peace." 14 At the same time, the Soviet government instructed its military authorities to enter into preliminary negotiations with the military representatives of the Central Powers. The objective of these negotiations would be the immediate ceasing of all military operations on the Russian front and, if need be, the establishment of a separate peace treaty between Germany and Soviet Russia.

The American response to this action was stern. The United States, committed to a military victory over Germany, could not but "categorically and energetically protest against any separate armistice which may be made by Russia."15 Thus, the United States announced an embargo on supply shipments to Russia and warned that "the exports to Russia will be resumed only after the formation of a steady government which can be recognized by the United States, but if the Bolsheviks will remain in power and will put through their program of making peace with Germany, the present embargo on exports to Russia will remain in force." 16 Furthermore, the new Soviet government was reminded of the treaty of September 5, 1974 which precluded any separate armistice. The United States warned the Bolsheviks therefore, that "any violation of the treaty by Russia will be followed by most serious consequences." 17 
majoritarian opposition within his own party, ${ }^{18}$ Lenin then submitted to the treaty of Brest-Litovsk. The initial phase of U.S.-Soviet relations was overshadowed therefore, by the hostility and animosity that resulted from different perspectives on the need to pursue military operations against the Central Powers.

Notwithstanding the obvious impact that it had on the exacerbation of tensions between the United States and Soviet Russia, Lenin's "Decree on Peace" should be noted most for the apparent contradiction that it represents in Leninist ideology. Here was a revolutionary obsessed with the need for violence, armed revolutions, and revolutionary wars as important determinants in any socialist transformation. Yet, his first official proclamation after assuming control of the seat of Russian power was one that called for peace and a termination of military hostilities. This apparent paradox is easily dispelled upon a closer examination of the ideological thought of Lenin in regard to the topic of war. It was this view of war that dictated the strategy pursued by the Bolsheviks during World War I, and also provided the guiding principle for the formulation of the policy of detente.

The subject of war and peace constituted a major portion of Leninist ideology. In addition, a good deal of Lenin's philosophy regarding war has, to this day, lingered in the official volumes of communist doctrine.

Lenin adhered to the definition of war developed by Clausewitz. Hence, he could claim that, "as applied to wars, the main thesis of the dialectic is that 'war is simply the continuation of politics by other (i.e., violent) means. " Lenin further felt that this view was "always the standpoint of Marx and Engels, who regarded every war as the 
continuation of the politics of the given interested powers." 19 Furthermore, Lenin applied this theory to the peace that would ensue after any war:

Just as all war is but the continuation by violent means of the politics which the belligerent states and the classes that rule in them have been conducting for many years...so the peace that succeeds every war can be nothing else than a summing up and registration of the changes in the relation of forces brought about in the course of, and in consequence of, the
given war. 20

Lenin had not always subscribed to the belief that wars, especially of an international magnitude, could provide the needed stimulus for a socialist transformation. His vacillation in this regard provided one of his first cases of "lowering of theoretical standards." As a delegate of the Russian Social Democratic Labor Party to the 1907 Congress of the Second International, Lenin agreed with the resolutions of that conference that called for the immediate termination of any international war. Such wars, in the view of the International, could not assist the world socialist movement. Rather, they could only succeed in causing greater hardships and agonies for the already oppressed masses. Hence, Lenin had clearly sided with those who believed that a worldwide conflagration, such as World War I, must be opposed by all Marxists with a resolute and unyielding pacifist stance.

Lenin, however, proved his mettle as one of history's greatest opportunists, and quickly saw the inestimable revolutionary value provided by the massive spread of the world's first international military holocaust. As the First World War brought its unparalleled destruction and devastation throughout the entire European continent, Lenin devoted all his tireless energy to a campaign that would eliminate any pacifist stance toward the war. Lenin replaced this view with revolutionary action aimed at 
transforming the conflict into a socialist revolutionary war that not only would topple the czarist monarchy, but would herald the complete downfall of the entire world capitalist system. In addition, Lenin argued that any imperialist alliance during or after this war was temporary in nature, as murderous wars between them were inevitable:

Peaceful alliances prepare the ground for wars, and in their turn grow out of wars; the one is the condition for the other, giving rise to alternating forms of peaceful and non-peaceful struggle out of one and the same basis of imperialist connections and the relations between economics

The first four months of U.S.-Soviet relations were characterized by the Leninist quest to export the new socialist revolution to the nations of the West. Overcome with the euphoria that accompanied their swift acquisition of power, the Bolsheviks wasted few diplomatic courtesies and points of protocol in their attempt to topple the governments of the capitalist-imperialist system.

It is not surprising that American statesmen were quite aghast when listening to this steady flow of unheard of progaganda from a government that stood for every policy and belief that was inimical to the interests of the United States. Here was a government that had repudiated all codes of ethics and morality, outside of their own, and denounced them as "a deception, a fraud, which clogs the brains of the workers and peasants in the interests of the landowners and capitalists." 22 The Soviets had deprecated the notion of a God as "a complex of ideas begotten by the cross submissiveness of man, by external nature and by class oppression - ideas which tend to perpetuate this submissiveness, to deaden the force of the class struggle." 23 The United States quite accurately saw a nation, in Soviet Russia, which was unheralded in its own obsession with war, violence, terror and an indomitable passion to 
export its successes to every non-socialist nation on the globe.

Furthermore, Lenin let it be known that this exportation of the socialist transformation would not involve peaceful methods. As Lenin claimed:

"the proletariat cannot achieve victory without breaking the resistance of the bourgeoisie, without forcibly suppressing its enemies. "24 In regard to the United States, Lenin was emphatic on the need for violence. Lenin felt that "the replacement of the bourgeois by the proletarian state is impossible without a violent revolution," and that "today, both in England and America, the 'precondition of any real people's revolution' is the breakup, the shattering of the 'ready-made state machinery. "25

Lenin and his Soviet spokesmen were also something less than courteous in other remarks about the United States in this early period. In his treatise State and Revolution, Lenin had clearly marked the United states as one of the most obvious examples of a ruthless state serving as the instrument for the exploitation of the oppressed classes. This was true, according to Lenin, by virtue of the government's "direct corruption of officials" and by "the alliance of the government with the stock exchange." 26 Furthermore, Lenin castigated the United States for the unprecedented extremes of its class contradictions:

...America has become one of the foremost countries as regards the depth of the abyss which divides a handful of brazen billionaires who are wallowing in dirt and in luxury on the one hand and millions of toilers who are always on the verge of starvation. 27

When President Wilson sent his message to the new Soviet government expressing his solidarity with the Russian people in their "attempt to free themselves forever from autocratic government and become masters of their own life," 28 the Bolsheviks responded in a manner that the American chief executive had never before experienced. The Soviets 
caustically replied that they take "the opportunity of President Wilson's message to express to all peoples, suffering and dying from the horrors of imperialist war, its warm sympathy and its firm belief that the happy time is not far distant when the laboring masses of all the bourgeois countries will throw off the yoke of capitalism and establish a socialist state of society." 29 The Soviet preoccupation with the exporting of their revolution would cloud every issue of early Soviet-American relations, and would come to an end only after Lenin realized that this "happy time" might well be in the very distant future.

\section{8: The Birth of Detente}

Most Western experts on Soviet foreign policy characterize the year 1921 as the starting point for a basic re-aligning of Soviet foreign policy objectives. Consequently, 1921 is often seen as the time when peaceful coexistence became a viable alternative to the heretofore inalterable policy of revolutionary confrontation. In his classic Expansion and Coexistence: The History of Soviet Foreign Policy, 1977-1967, Adam B. Ulam labels 1927 as a "watershed in Soviet internal as well as external politics" as it ushered in an era that "witnessed the elaboration of a new pattern of Soviet foreign relations." 30 Likewise, George Kennan saw 1927 as a time when "relations with the Western governments achieved a new seriousness in the eyes of the Soviet leaders; and they now allotted a high priority to their development." 31 It would be difficult to dispute the claims of such noted scholars that 1921 marked an important and critical time in Soviet history. To be sure, this year was highlighted by the beginning of a new era in the theoretical and practical formulation of the Soviet world outlook. However, there is evidence to show that the 
Kremlin hierarchy, as early as March of 1918 with the signing of the treaty of Brest-Litovsk, had already started the process of realigning Soviet foreign policy. At that time Lenin, as will be presented below, realized that a detente relationship with the west in general, and the United States in particular, was necessary.

The detente of 1918 can be seen as a policy that was unilateral in nature. This detente did not include the full ramifications of the policy that would be developed later (e.g. formal diplomatic relations, treaties, reciprocal trade, etc.), but entailed a detente from the Soviet perspective. Lenin was convinced that the new Soviet regime should pursue a policy of coexistence based on a number of realistic assessments, including the objective reality that a breathing spell was needed for the implementation of internal consolidation. Yet, no Western government, due to their preoccupation with the war and their basic mistrust of the Bolsheviks, would engage in any reciprocal relationship with the Soviet government at this time.

Lenin, in his frenzied quest to implement a socialist revolution in all parts of the capitalist world had hinged much of his hope on the success of an immediate uprising in war-weary Germany. It was here, in Lenin's view, where the entire fate of the European socialist transformation was being determined. If Germany had met with success from Lenin's perspective, then the worldwide socialist transformation might well have been realized as an immediate goal of his revolutionary party. As Lenin declared:

If the German revolution were to break out and triumph in the coming three or four months, the tactics of an immediate revolutionary war might perhaps not ruin our socialist revolution. 32 
German uprising were not good. He then stated that "it would be absolutely impermissible tactics to stake the fate of the socialist revolution...merely on the chance that the German revolution may begin in the immediate future, within a matter of weeks. Such tactics would be a reckless gamble. We have no right to take such risks." 33 The fact that the global socialist transformation depended on the events in Germany, and that this revolt was not forthcoming as planned, then became a matter of official policy.

At all events, under a 11 conceivable circumstances, if the German revolution does not come we are doomed.

The revolution will not come as quickly as expected. History has proven this, and we must be able to take this, as a fact, to reckon with the fact that the world socialist revolution cannot begin so easily in the advanced countries as the revolution began in Russia.34

Lenin was also aware that a number of internal difficulties had made it imperative to secure a breathing spell and to postpone any external revolutionary activity for the time being. With the outbreak of the civil war in Russia, Lenin, although convinced of the ultimate Bolshevik victory, was forced to concede that "some time must inevitably elapse, no little exertion of effort will inevitably be required, a certain period of acute economic dislocation and chaos, which accompany all wars, and civil wars in particular, are inevitable, before the resistance of the bourgeoisie is crushed." 35 In addition, as Lenin admitted, his government was plagued by sabotage and terror from the newly disenfranchised bourgoisie. This sabatoge had, in his words, "proven so stubborn and capable of assuming such diversified forms that the fight against it will inevitably require some more time, and in its main forms, is hardly likely to end until several months have passed." 36 Lastly, Lenin had to take note of the critical food situation and the 
danger of famine and concede that "the organizational problems of the socialist transformation of Russia are so immense and difficult that their solution...will also require a fairly long time." 37 What Lenin required then was a "certain amount of time, several months at least, during which the hands of the socialist government must be absolutely free to achieve victory over the bourgeoisie first in our own country and to launch far-reaching mass organizational work on a wide scale. "38 Lenin then announced, in detailed form, in his article "The Immediate Tasks of the Soviet Government," a policy that can be equalled with detente, in its earliest form:

All our efforts must be exerted to the very utmost to make use of the respite given us by the combination of circumstances so that we can heal the very severe wounds inflicted by the war upon the entire social organism of Russia and bring about an economic revival, without which a real increase in our countries defense potential is inconceivable.

It also goes without saying that we shall be able to render effective assistance to the socialist revolution in the West, which has been delayed for a number of reasons, only to the extent that we are able to fulfill the task of organization confronting us. 39

To do otherwise, in Lenin's view, and to embark upon a course of direct confrontation with the West would be of the utmost folly. While answering "the human yearning for the beautiful, dramatic and striking," it "would totally disregard the objective balance of class forces and material factors at the present stage. To ignore the objective balance of class forces on the issue would be a fatal error." 40 Thus, it was necessary for Lenin to enter a period of detente, and to direct the energies and activities of the new government to the formidable array of enemies, both of man and nature, that had aligned themselves against the Bolsheviks. To do this Lenin created the world's first detente between the two conflicting socio-economic systems. This detente, although 
temporary in nature, would then become a major component of Soviet foreign policy.

The concept of detente, in view of this evidence, was not coincidental with the formulation of Soviet Russia, as contemporary Soviet historians would have us believe. The evidence would also show that it was not designed at the same time as the implementation of the New Economic Policy, as some Western observers claim. Rather, it can be reasoned that it was a product of the Leninist realization that the mass of serious domestic problems had made co-habitation of the world with the capitalist powers an unfortunate though temporary necessity. This program was detailed in its entirety by G.V. Chicherin in his report on foreign policy to the Fifth All-Russian Congress of Soviets. This report deserves some attention on our part here since it graphically outlines the basic principles of detente that would remain uniform for decades to come. According to the Soviet Commissar for Foreign Affairs, "in the period following the conclusion of the Brest treaty, Russia's foreign policy has gone along lines different from those followed in the first months after the October revolution." 41 Chicherin then fully enunciated the meaning of this difference:

At the end of 1917 and the beginning of 1918 the basic feature of our foreign policy was the revolutionary offensive. It took its bearings from the immediate prospect of the world revolution, for which the Russian revolution was to serve as the signal.

...For the last four months it (Soviet Russia) has been compelled to pursue the aim of pushing off and postponing the dangers threatening it from all sides, trying to gain as much time as possible...for the new forms of political and social relationships established by the Soviet Government to take root among the popular masses of Russia.

The position of Soviet Russia between two imperialist coalitions, like being between two fires, is extremely difficult, but we can say with full confidence that the best and indeed the only way that we can overcome this position is by 
internal consolidation... and by the re-creation of a military

force for the protection of the conquests of our revolution.

The nearer we come to realizing this aim, the better our position abroad will be; our foreign policy is dependent on

It is debatable as to how long this period of detente was to last, or exactly what its full dimensions and parameters would be. The key variable, outside of internal consolidation and a military resurgence, was the now less than enthusiastic prospect of other socialist revolutions. As Chicherin declared, the Soviets were resting and recuperating but still "awaiting the moment when the proletariat of other countries will help us to complete the socialist revolution we began in October." 43 Much the same sentiment was expressed by Lenin when he claimed:

We are now as if in a beleaguered fortress until other detachments of the international socialist revolution come to our rescue. But these detachments exist, they are more numerous than ours, they mature, they grow, they become stronger as the bestialities of imperialism continue. 44

However, such incantations may have served as no more than an exercise in the ritualistic recital of propaganda verbiage paying homage to a long-awaited dream that had been dashed upon the rocks of the failure of the worldwide socialist revolution. The Soviet government, although paying lip service to the cause of global socialist transformation, had already begun to test the waters of reciprocal economic and trade relations with the United States in the Spring of 1918. Chicherin in his aforementioned report had alluded to the Western willingness to engage in normal state-to-state relations in the economic realm, and claimed that "instead of a policy of robbery, these elements in both coalitions would prefer a policy of trade, of concessions and economic conquests." 45 Earlier, Trotsky, as Soviet Commissar for War, had 
addressed an appeal to the United States government, through Colonel Robins, the head of the American Red Cross mission in Russia, in which he inquired as to "what kind of support would be furnished particularly and especially by the United States," should the German government break the treaty of Brest-Litovsk in order to renew "its robber's raid." 46 Incidentally, Trotsky had earlier stated his belief that the United States was, or would soon be, interested in developing an economic rapport with the new Soviet regime. According to the Commissar for War:

America can be tolerant with regard to the existence of the Soviet Government, since it is satisfied with the exhaustion of the Allied countries and Germany. Apart from that America is interested in investing its capital in Russia. 47

Lenin himself, on May 14, 1918 gave his official stamp of approval to the normalization of trade relations, in a lengthy and elaborate plan for Russian-American commercial relations that he sent to Colonel Robins. In this plan Lenin, in great detail, delineated a system of trade whereby the fledgling Soviet state would gain much needed "tools of production" by granting concessions to the United States for the development of Russian raw materials. According to this preliminary plan, Lenin fully realized that "without the assistance of countries, which are producing a large quantity of the tools of production for agricultural purposes as well as parts of railroad stock, it will not be easy for Russia, and she will not be able with any degree of speed to overcome all the difficulties of re-establishing the economic life of the country." 48 Furthermore, Lenin acknowledged the fact that the United States, as the nation that was not ravaged during the havoc of World War I, would, if it so desired, become the leading trading partner with Soviet Russia. Lenin fully conceded the fact that Germany, the chief 
commercial dealer with pre-war Russia, had been so devastated by the war that it was "compelled to surrender her leading place as the source for the economic life of Russia for the next few years to a country which has not been disorganized as much as Germany by the war. Only America can become that country." 49 Aware that Russia would be unable to pay for the American products imported by his government, Lenin devised a system of economic concessions, which would be repeated and emphasized with greater intensity in 1921 with the implementation of the more elaborate coexistence strategy. The May, 1918, plan for paying the United States called for the following concessions and guarantees to America, which could:

...participate actively in the exploitation of the marine riches of Eastern Siberia, of coal and other mines, as well as in the railroad and marine transportation construction in Siberia and northern European Russia. Especially in the construction of the Northern Sea route with the Enisei River, the improvement of water routes, building of ports and using of the water power, there is great need.

As security of payment for products brought into Russia, America could be given the privilege of participating in certain construction enterprises... The United States could also participate on a large scale in the development of certain we11-known extensive agricultural tracts, by introducing modern methods, receiving in return a large proportion of the products.

Further, Russia guarantees that the military stores which are on hand in Russia will not be sold to Germany, and that all war materials which were manufactured in England and America for Russia will be transferred to the United States. 50

As early as the Spring of 1918, Lenin had conceived and graphically detailed both the imperative need for a period of detente as well as the course that this policy would take in the economic realm. If we assume that Lenin was quite serious in his belief that the economic revival of Soviet Russia was of utmost paramountcy, and that he honestly wished to enlist the direct participation of the United States in effecting this goal, it is logical to further assume that the policy of coexistence 
was to be of a fairly long duration. As Lenin explained, the internal and economic difficulties confronting his government were of such magnitude that a rather long period of time would be required to solve them. It can then be logically reasoned that in 1918 Lenin had created and substantiated the policy of detente that, while being relatively temporary in nature, would, nonetheless, serve as the main determinant of Soviet foreign affairs for the foreseeable future. Moreover, detente would continue until such time as the new government could fully consolidate its economic and military power. These variables would come to the fore again in 1921 when Lenin, further convinced of both the failure and poor prospects of an immediate socialist revolution outside of Russia, and of the need for Western credits and economic assistance, would advance, in greater detail, a blueprint for coexistence with the powers of the capitalist-imperialist system. However, it would be incorrect to ignore the fact that only four months after the Bolshevik takeover Lenin had already acknowledged the urgency of effecting a much needed breathing spell in order to forestall any immediate confrontation with the West. The preliminary plan for U.S.-Soviet commercial relations, drafted by Lenin and presented to a representative of the American government, bears testimony to this early realization on the part of the Soviet leader. On the same day that Lenin publicized his plan for economic relations with the United States, he addressed the Central Executive Committee of the Soviet government. Here, he presented a sober and realistic assessment of the present Soviet conditions and outlined a course of action that would be followed for an indefinite period of time. Taken together, these two reports, delivered on the same day, will provide us with a complete enunciation of the Leninist policy of peaceful 
coexistence including the underlying motivation and rationale for the policy as well as the manner in which it would be pursued.

In his report to the Central Committee Lenin acknowledged the fact that the socialist revolutions in the Western capitalist states had stalled. Therefore, he claimed that "for a number of reasons of an economic and political character which you are aware, the different rate of development, the difference between conditions here and in the West, our Socialist republic remains, for the time being, an oasis in the middle of a raging sea of imperialist rapacity. "51 With the hopes for an immediate revolutionary surge in Germany diminished, Lenin, as he reported, had to resort to a strategy of waiting and employing new tactics against the West. According to Lenin, the Soviets had to hold on to and consolidate their present position "until our ally, the international proletariat, catches up with us - and it undoubtediy will, although incomparably more slowly than we would have liked. We must stick to our waiting tactics and exploit the conflicts and antagonisms among the imperialists, slowly accumulating strength and maintaining the oasis of Soviet power in the middle of the raging imperialist sea." 52 These particular "antagonisms" were identical to those which Lenin would delineate in 1921. In the first place, Lenin recognized "the struggle between Germany and England on the western front, which has reached the limit of ferocity," and secondly the severe antagonism between Japan and America which had only been "concealed for the time being by their alliance against Germany." 53 At this time, Lenin was still totally committed to the view that the imperialist powers would, sometime in the future, align themselves in a joint and massive assault on the government that had dared to construct a socialist socio-economic 
system. However, Lenin reasoned that the imperialists were locked in their own life and death struggle for the moment, and consequently, had precluded any chance of an imperialist alliance. This condition had afforded the Soviet regime a life saving respite. Faced with this situation, Lenin had but one choice in regard to the tactics and strategy his government would employ:

...we shall do everything to prolong that brief and precarious respite which we got in March, for we are firmly convinced that we have tens of millions of workers and peasants behind us, who are gathering new strength and consolidating the Soviet power with every week, every month that the respite lasts, and within whom the determination is hardening to enter the last decisive battle when external forces descend upon the Socialist Soviet Republic. 54

If we sum up the arguments advanced by Lenin in his two statements of May 14, 1918, we will find a complete portrait of the Leninist detente policy. This strategy was based on the convictions that; 1.) the Soviet republic urgently and desperately required a breathing spel1, a respite by which the new government could concentrate all its efforts at consolidating its power and overcoming the awesome political, social, and economic problems which confronted it in the domestic sphere; 2.) the worldwide socialist upheaval, especially in Germany, had been delayed for a number of reasons, thus forcing the soviet government to remain isolated in an imperialist world and compelling it to render little, if any, meaningful assistance to the cause of global revolution; 3.) the inordinate East-West military imbalance and the relative anemia of the Soviet armed forces made it impossible for the Bolsheviks to engage in any military confrontation with the West, and underscored the need for a drastic realtering of the East-West military equation; 4.) the prospect of a final and fatalistic military confrontation between the powers of capitalism and socialism was guaranteed as an historical inevitability; 
5.) the capitalist-imperialist nations would eventually form an alliance and launch an offensive against Soviet Russia, an offensive that could not be precluded by detente, which was geared to preparing for this inevitability; 6.) Lenin could not effectively restore economic stability to his country without securing the much needed economic assistance and trade credits from the West, and specifically from the economically powerful United States which possessed the most advanced level of scientific and technological expertise, and which was the least impaired of the warring nations of World War $I ; 7$.$) the Soviet government could$ prolong this life-saving respite by exploiting and manipulating the inherent contradictions in the imperialist camp and by doing all in its power to transform these contradictions into open warfare between them so as to postpone the eventual anti-Soviet alliance of imperialists; and 8.) the socialist system would inevitably gain a complete triumph over the capitalist-imperialist system. The tactics of waiting and consolidating strength were therefore, logistical components of a strategy that had the final destruction of capitalism and the concomitant socialist transformation of the world as its ultimate objectives.

A major hypothesis of this dissertation is that detente in 1972 was a continuation of the detente of 1918. Detente, it will be shown, was created by Lenin and developed by Stalin, Khrushchev, and Brezhnev. In fact, the detente of 1980 , though tempered by recent events, will be viewed as a direct descendant of the policy conceived by Lenin less than one year after the Bolshevik seizure of power.

It is important therefore, to analyze the eight major components of the Lenin detente of 1918. By so doing, the historical continuity in detente from 1918 to the present will be more clearly manifested. 
The different eras of detente, and most importantly the Brezhnev era, will be discussed in some detail below. However, a cursory glance at these periods would be in order here, in light of the eight initial factors that originally governed the creation of detente in 1918. The main focus in this brief overview will be on the similarities in the basic constitution of detente as practiced by the four major soviet regimes.

In the first place, it should be noted, as will be discussed below, that all eight variables that served as motivational factors for detente in 1918 were identical to those that provided the stimulus for the same policy in 1921. At that time, it was still necessary for Lenin to secure a breathing spell with the West in order to focus on the goals of internal consolidation. This was especially true in the light of the further domestic problems caused by the civil war. The prospects for a European socialist revolution appeared to Lenin to be even more remote in 1921 than they were in 1918. The imperialist nations had also escaped from the First World War unscathed, in terms of any Bolshevik-styled upheaval. The East-West military equation, which would determine the outcome of the inevitable inter-camp war, was still heavily weighted in the favor of the capitalist-imperialist camp. The possibility of an anti-Soviet alliance among the Western nations was a more ominous threat by virtue of the fact that the capitalist-imperialist nations were now free of the war. The Soviet regime was still desperately in need of Western trade and economic benefits and, while trying to secure them, was mindful of the urgency of exploiting the contradictions and inherent antagonisms in the imperialist camp. Finally, the Soviet leaders in 1921, as they were in 1918, were convinced of the inevitability 
of the historically-guaranteed triumph of the socialist transformation, and the ultimate defeat of the antithetical socio-economic system.

These eight variables, which dictated the efficacy of pursuing a policy of coexistence in 1918, were very similar to those which made detente a primary requisite for the formulation of Soviet foreign policy during the Stalinist years. There would, of course, be obvious tactical variations injected into the politics of detente during this era. The Stalinist period covered nearly thirty years of Soviet history, and witnessed, among other things, the transformation of the Soviet state from an "oasis in the raging sea of imperialism," to the acknowledged head of a system of socialist countries. However, at one time or another, the policies of rapid industrialization, forced collectivization, socialism in one country, capitalist encirclement, the blood purges, the alliance of World War II, the tremendous Soviet wartime losses, the American nuclear capability, and a host of other factors all contributed to the utmost urgency of maintaining a detente posture as outlined by Lenin in 1918. The Khrushchev years, for their part, saw the policy of detente being transformed from a tactic of waiting and consolidating strength to an offensive strategy, whereby the concept of coexistence itself, would serve as the stimulus for the dissemination of socialist influence. This period witnessed the demise of three variables in the Leninist formula. The Soviet Union no longer had to consolidate its strength internally, was not isolated as a socialist oasis, and did not adhere to the theory of wars as a fatalistically inevitable guarantee of historical development. Yet, at the same time, the strategic military superiority of the United States, the existing possibility of a reckless anti-Soviet thrust by the imperialists, the need for expanding 
economic contacts with the West, the urgency of exploiting the antagonisms of the imperialist world, and the dictates of the ideology of world domination remained fixed in the Soviet strategy of detente during Khrushchev's tenure in power.

The present regime, as we have seen, has further altered some of these principles of detente. The major revision, in this writer's view, is concerned with the "correlation of world forces," an important consideration for Soviet theoreticians from the very inception of Soviet power. This equation has finally, from Moscow's point of view, been weighted in favor of world socialism. With the achievement of an effective strategic parity with the United States, the Soviet Union, unlike past years, is not overwhelmingly concerned with erasing an awesome gap in the military capabilities of the two competing systems. However, much of what Lenin said in 1918 can, with a good deal of accuracy, be applied to the present situation. Contemporary Soviet leaders must, as they have often repeated, guard against a possible imperialist attack. The capitalist world, hopelessly frustrated by the advancements of the socialist camp, might very well attempt one desperate, and fruitless assault in order to thwart the unstoppable march of communism. The present leadership is also cognizant of the urgent necessity of infusing mass amounts of much needed Western scientific and technological advancements into the Soviet economy, and of expanding reciprocal trade and economic agreements with the West. Brezhnev, although somewhat less obtrusive than Lenin, has also realized the need for exploiting every manifestation of antagonism and conflicting interests among the powers of world imperialism. Finally, the present Soviet government has reinforced its belief, based on the convictions of Marxist-Lenirist 
ideology, that, through gradual and incremental changes, the capitalistimperialist system will inevitably give way to the communist world order.

For a number of reasons, however, the detente policy of 1918 , although fully defined and elaborated by Lenin, was never fully incorporated into a bi-laterial and reciprocal code of conduct with the nations of the West. The apparent reason for this was that no nation of the capitalist system was either willing or able to entertain any thoughts of entering into a mutually acceptable political or economic arrangement with a revolutionary government that had vowed to destroy it. It can be reasoned that there were two elemental factors that prompted this unreceptive stance on the part of the Western powers and precluded any meaningful rapport on their part with Soviet Russia. In the first place, the capitalist nations were still concerned with the First World War, and placed a premium on effecting changes that would permit the Russian military forces to reopen the Russian front. Thus, in no way, would the creation of amiable relations with the government that had closed the Russian military theater and induced a potentially fatal military predicament in the West, have served the primary interests of any country in the Allied camp. Secondly, the nations of the West held nothing but the most utter contempt for the Bolsheviks and looked upon their government as some form of temporary madness that, in due time, would give way to more responsible and traditional forms of leadership. Lenin and his henchmen were, it was held, nothing more than fanatical, conspiratorial terrorists whose reign could never stand the tests of time. When the Russian people came to their senses the Bolshevik faction would, in this view, be overthrown. Both of these perceptions 
would change in 1921. The governments of the west, free of their commitment to the war, and more inclined to believe, in light of the Red Army's victory in the Russian civil war, that the Bolsheviks were there to stay, were more receptive to negotiating with the Soviet government. The fact that the West was not receptive to the Soviet overtures for detente in 1918, however, does not mean that detente did not exist then. Similarly, the United States may not be strongly pursuing detente today in the wake of the Soviet invasion of Afghanistan; yet detente, as will be shown, still exists in 1980. A major theme of this study is that detente is a long-term and fundamental soviet policy. Detente was designed and implemented by the Soviet regime as the best means by which it could protect, and eventually expand upon the revolutionary gains that it had achieved. From the Soviet perspective, there would be no major qualitative changes in the basic composition of detente from 1918 to 1921. It will be shown that the primary difference in the policy would be in the more receptive response given to it by the nations of the West.

\section{The Revitalization of Detente: 1920-1921}

The two and one-half year period from the ratification of the Brest-Litovsk treaty to the winter of 1920-1921 witnessed a low level of understanding in the relations of Soviet Russia and the non-socialist nations of the world. For the reasons outlined above, the capitalist nations were unwilling to conduct anything resembling amiable relations with the new and radical Soviet government. The strains in Soviet-Western relations were manifested in many ways by the policy of intervention in Soviet Russia; a policy that did little to enhance the possibilities of 
fostering a mutual detente. The Allied intervention in Russia is a subject that is far too complex for any lengthy discussion here. It is interesting, however, to examine the effects that American participation in this joint Allied venture had on the Soviet policy of detente with the United States.

Contemporary Soviet historians are fond of portraying American intervention in terms of an attempt by the United States to assist in the overthrow of the Soviet regime. Such a view engages in a bit of historical distortion that is not altogether foreign to Soviet propagandists. Historical evidence indicates that the United States was the last of the Allied powers to concede to the policy of intervention, and did so with the incessant urging of the British and French governments. Moreover, it can be shown that the United States pursued objectives in Soviet Russia that were directly related to the final consummation of World War I.

The United States sent a total of 3,950 troops under British command to the northern Russian port of Arkhangelsk. 55 The objectives of this small contingent were to: 1.) safeguard the 162,495 tons of war supplies from German acquisition; ${ }^{56}$ 2.) forestall any German advances in the northern regions of Russia; 3.) preclude the establishment of a German submarine base at Murmansk or Petchenga, 57 and 4.) keep the northern front open in the hopes of eventually persuading the Soviets to re-enter the war.

The American forces dispatched to Siberia were sent with a set of objectives that were less clearly defined than those in the north. As the commander of the U.S. contingent in Siberia, General William S. Graves, stated, "I was in command of the United States troops sent to 
Siberia and I must admit, I do not know what the United States was trying to accomplish by military intervention." 58 officially, the United States attempted to achieve three basic goals in Siberia: 1.) the protection of a stockpile of war munitions; 2.) assisting a legion of Czech-Slovak troops in leaving Soviet Russia, and 3.) guarding sections of the Trans-Siberian Railway. ${ }^{59}$ Unofficially, however, the United States was alarmed by the presence of some 72,000 Japanese troops there, and hoped to discourage any military designs by Japan with the existence of a strong American military contingent. 60

As a contributing factor to the development of hostile SovietAmerican relations, the American intervention should have been a variable of little concrete substance. Yet, the Soviet government of Lenin did not look upon it as such. The Bolsheviks immediately launched an intensive propaganda campaign against the United States and claimed that America was trying to kill the infant Soviet state. Such a view was epitomized by Chicherin in an official protest that he sent to President Wilson. Chicherin first reminded the American chief executive of his promise "to collaborate with Russia in order to obtain for her the unrestricted and unembarrassed opportunity for the independent determination of her political development and her national policy." Chicherin then listed the tangible results of this pledge of good will:

In fact this collaboration took the form of an attempt, first on the part of the Czech-Slovak troops and later, in Arkhangelsk, Murmansk, and the Far East, of your own allies' troops, to force on the Russian people the rule of those oppressing and exploiting classes whose power was overthrown by the workers and peasants in Russia in October of last year. 61

Lenin further claimed that, "Wilson proved to be a fool," and that "the roots of Wilson's policy amounted only to the piffle of 
parsons-petty Bourgeois phrases-and the utter failure to understand the class struggle."62 The United States' response typified the level of animosity that existed between the two countries. In the words of Secretary of State, Bainbridge Colby, "the existing regime in Russia is based on the negation of every principle of honor and good faith, and every usage and convention underlying the whole structure of international law." 63

Lenin was aware, however, that U.S.-Soviet relations, regardless of the animosities caused by the intervention, had to be immediately re-channeled into the detente framework that he had created in 1918 . In Lenin's mind there were now two decisive factors that compelled him to embark on a more energetic and substantive form of detente with the United States. The first of these centered on Lenin's accurate assessment that the imperialist countries would be more receptive to the Soviet overtures for initiating traditional forms of diplomatic relations. In addition, the nations of the West would now find it to their advantage to expand what could prove to be mutually beneficial economic and trade agreements with Soviet Russia. The Bolsheviks had demonstrated by this time that they were not the leaders of a "short-lived" fanatical movement, but were the recognized heads of the Russian government. The nations of the West, if indeed they wished to conduct a Russian policy, would have to do so with the Bolshevik regime. Having survived the Allied intervention, and having defeated the formidable array of antiBolshievik forces in the civil war, the Soviet regime had dispelled any hopes, certainly for the time being, that their government would soon be overthrown and replaced with a more amiable political organization. Furthermore, Lenin reasoned that the potential exploitation of the vast 
resources of Russian raw materials now, more than ever, loomed as an attractive temptation for the economically ravaged combatants of the First World War. Thus, Lenin reasoned that the mitigating circumstances that induced the West to ignore his original detente plea in 1918 had dissipated to the point that the nations of the capitalist system would now be forced to both recognize and negotiate with his government.

The second consideration is that Lenin, after carefully analyzing the internal and international situation of the Soviet state, deduced that peaceful coexistence, even more so than in 1918, was a compelling necessity for his government. For a number of reasons, which will be detailed below, Lenin realized that the detente of 1918 had not, by 1920 , solved the problems to which the detente-inspired respite was addressed. Consequently, Lenin felt that the policy had to be extended and revitalized. This is not to say that Lenin altered or revised his detente strategy, since, as was outlined above, the basic principles of the policy were not changed. However, the intensity and vigor with which the coexistence plan was pursued had been noticeably increased.

Lenin was now confronted, as he had forecast, with the further proliferation of economic and social dislocation caused by the waging of a fierce civil war. This, coupled with the already existing breakdown of communications, and transportation, and the general state of economic instability made for a rather unenviable domestic environment. This situation was further aggravated by the great famine which plagued the country, and by the shattering reality of political discontent that was manifested by the Kronstadt rebellion. Lenin also knew that the prospect of a worldwide transformation had grown dimmer during this time. The war had not, as he had hoped, sparked a revolutionary upsurge in the West. 
and the socialist parties there, unwilling to employ the Bolshevik tactics of terror, violence, and illegality, had forced Soviet Russia to remain as an "oasis" for some time to come. The urgent necessity of securing foreign credits and of engaging in a beneficial trade relationship now became all the more imperative for Lenin if he were to meet with any success in completing the objectives of internal consolidation and of restoring the economic vitality of the nation. It can be argued that the most important realization by Lenin at this time was the potential anti-Soviet alliance that could be a result of the termination of the First World War. Lenin felt that the imperialists, at the first given opportunity, would unite in a joint venture aimed at the destruction of the socialist intruder. Yet, as he mentioned during the war, "the imperialist war, which has divided the imperialist powers into two hostile groups locked in a life and death struggle, has for the time being, and in the given conditions, made this alliance of the imperialists of all countries impossible." 64 Now that World War I had ended there was nothing to prevent such an alliance, and it behooved Lenin to augment and replenish the tactical strategy he devised to postpone this occurrence. The Bolsheviks were compelled, in their view, to exploit and utilize every contradiction and antagonism that existed in the imperialist camp and to instigate and generate inter-imperialist hostilities so that the imperialists, in the interest of protecting their vested economic interests, might more readily fight among themselves.

The end of World War I was the one factor that apparently worried and distressed Lenin the most in regard to the disastrous effects it held for his socialist government. The imperialists would never quietly acquiesce in the demise of their system, which was heralded by 
the formation of a socialist state. Rather, they would, in Lenin's mind, resort to any and all means, now that the war was over, to crush the Bolshevik regime. That such a view was basic to the Soviet world outlook was reinforced by a resolution of the Seventh Communist Party Congress:

At this time, when the era of socialist revolution has opened, recurrent military attacks on Soviet Russia by the imperialist states (both from the West and the East) are historically inevitable. The historical inevitability of such attacks, given the extremely acute stage now reached both in the internal class relations and in the international situation, may at any moment, perhaps in the immediate future, perhaps within the next few days, lead to an imperialist offensive against the socialist movement in general and against the Russian Socialist Republic in particular. 65

Reasoning on the basis of the theories he espoused in Imperialism, Lenin in late 1920, concluded that an "economic war," fostered by the imperialist quest to protect their own interests, was just around the corner:

That war is brewing, that war is inevitable, is beyond doubt... anybody who studies the history of economic relations and diplomacy cannot entertain the slightest doubt that an economic war is ripe and is being prepared politically.66

Lenin also felt that the lack of proper party organization and cohesion and the existence of "bureaucratic distortions" (all summed up in the "sickness" of the Party) would help foster this imperialist thrust. As he claimed, "undoubtedly, the capitalists of the Entente will try to take advantage of our Party's sickness to organize a new invasion." 67 That the future inter-camp war was inevitable, and that the termination of World War I had hastened its development, was a Leninist dictum of paramount importance in 1921. However, Lenin reasoned that the nearly prostrate Soviet state in 1921 was no more ready to wage this cataclysmic fight to the death than it was in 1918. To do so would have been, in 
Lenin's view, an inexcusable and fatal error. Fully aware of the military inferiority of the Soviet regime, Lenin, in 1920, declared that "to accept battle at a time when it is obviously advantageous to the enemy and not to us is a crime; and absolutely worthless are those political leaders of the revolutionary class who are unable to 'tack, maneuver and compromise' in order to avoid an obviously disadvantageous battle."68 Lenin needed time, much more time than his coexistence policy of 1918 had allotted him, in order to fulfill the tasks of military preparations and combat readiness needed for a successful conclusion of the impending intercamp war. Thus, it was incumbent upon Lenin to maintain an absence of war for an extended period of time and to engage in peaceful relations with the imperialist world. This was necessary, he reasoned, in order to utilize Western economic resources and expertise to both support his policies of domestic reconstruction and military efficiency, and to ready himself and his nation for the inevitable showdown.

Therefore, in 1921 Lenin, with great finesse, and in carefully elaborated detail, again launched his peace campaign which, in the main, amounted to a more vigorous and intensified version of his earlier detente. Lenin attached the greatest significance to this policy and devoted the majority of his time and his energy toward the acceptance and correct application of his strategy by his fellow Bolsheviks. There still existed many elements in the Party who desired more orthodox and revolutionary methods and who viewed detente as no more than a tactical selling out of basic Bolshevik principles. Thus, it was incumbent upon Lenin, in his usual virulent manner, to denounce any such radical beliefs. It was also necessary to convince all Party 
members of the correctness of the policy of adopting tactical flexibility and compromise of principle in regard to the strategy pursued at a time of relative weakness. Lenin began his campaign with a caustic denunciation of the "left wing" elements of the Party:

Genuine revolutionaries have most often broken their necks when they began to write "revolution" with a capital $R$, to elevate "revolution" to something almost divine, to lose their heads, to lose the ability in the coolest and most somber manner to reflect, to weigh up and to ascertain at what moment, under what circumstances and in which sphere it is necessary to act in a revolutionary manner, and when it is necessary to adopt reformist action.69

Furthermore, in Lenin's view the revolution would perish if the Party leaders "lose their sobriety of outlook and take it into their heads that the 'great, victorious, world revolution' can and must solve all problems in a revolutionary manner under a 11 circumstances and in all spheres of action." 70 To rely on such revolutionary and radical principles was an unpardonable mistake for Lenin. As he stated, "whoever 'takes such a view into his head' must perish, because he invents something stupid in connection with a fundamental problem; and in the midst of a fierce war (and revolution is the fiercest sort of war) the penalty for stupidity is defeat." 71 Coexistence with the west would require a classic case of Leninist compromise, fluctuation, and alteration of principles. Lenin, unable to condone the beliefs of those who would remain steadfast in their adherence to firm convictions, made this theme one of his favorite subjects, and one on which he dwelled at great lengths. History, according to Lenin, "knows all sorts of metamorphoses," and to "rely on firmness of convictions, loyalty, and other excellent spiritual qualities is not being serious in politics." 72 For Lenin, it was imperative to combine such firmness of conviction with the necessary adaptiveness to the present negative situation, such as the military 
weakness of the Soviet state. The Bolsheviks must adhere to the belief that "the strictest loyalty to the ideas of communism must be combined with the ability to make all the necessary practical compromises, to maneuver, to make agreements, zigzags, retreats and so on."13

The entire phenomenon of coexistence, although the only sane and logical method of conducting international relations, was, as Lenin admitted, a defeat of sorts for his Party, in that it represented a somber realization of the fact that the "complete (i.e., worldwide) victory of socialism" was a matter of future concern. It was important therefore, for Lenin to make his Party learn from such defeat and use it as a catalyst for future successes:

Do not be afraid of admitting defeat. If we agreed with the point of view that, like the surrender of positions, admission of defeat gives rise to despondency and relaxation of effort in the struggle, we would have to say that revolutionaries who give way to such despondency are not worth a damn.74

This view is synonymous with the position held by Lenin in March of 1918, when faced with the failure of the immediate German revoTution, he advanced his original concept of detente as a result of a defeat:

The most serious defeats await us, because we have no army, because we have no organization, because we cannot solve these two problems all at once. If you cannot adjust yourself, if you cannot bring yourself to crawl on your belly in the mud, you are no revolutionary, but a chatterbox, because there is no other way, because history did not work out so agreeably as to start the revolution in both countries simultaneous $7 y .75$

According to Lenin, it was precisely this kind of "defeat" that had confronted the Bolshevik Party in 1921 and it became apparent to him that the time had come for the Soviet revolutionaries to "crawl on their bellies" and abandon any attempt to reinstill the radical and violent revolutionary policies that had characterized their first few months 
of existence. Whereas in the past the Bolsheviks, as Lenin claimed, had placed a premium and "the main weight of emphasis on the political struggle, on revolution, on winning power, etc." it was now imperative to "shift the weight of emphasis to peaceful, organizational, 'cultural' work. "76 Lenin further reasoned that this peaceful work should not be limited to the domestic policies of the Soviet state. Instead, it would pertain primarily to foreign affairs, where the Bolsheviks had to conduct nonviolent and productive economic relations in order to secure much needed western assistance. The "proletarian state," according to Lenin, "must become a cautious, assiduous and shrewd 'businessman,' a punctilious wholesale merchant - otherwise it will never succeed in putting this small-peasant country economically on its feet." 77 so as to leave no doubt as to the ultimate objective of such a policy, Lenin graphically illustrated the aims of the peaceful "merchant and businessman" approach:

Under existing conditions, living as we are side by side with the capitalist (capitalist for the time being) West, there can be no other way of transition to communism...no matter what the costs, no matter how severe the sufferings of the transition period may be - despite disaster, famine, and destruction, we shall not lose heart and shall carry our cause to a triumphant conclusion. 78

Lenin was fond of using realistic historical analogies to illustrate and clarify his particular philosophy. It is not surprising therefore, that the detente strategy was heavily imbued with such allegorical comparisons. If we take the time to examine one of these lengthy Leninist expositions we will obtain a clearer picture of detente as Lenin saw it. Lenin was particularly impressed with a certain incident in the Russo-Japanese War of 1905, whereby the Japanese General Nogi had captured Port Arthur. The main importance of this episode is that it occurred in two distinct stages, as the celebrated Japanese commander 
was forced to alter his tactics in the midst of the operation. The original strategy was one of direct assault and storming of the fortress which resulted in a smashing Japanese defeat with heavy casualties. The general, faced with the hopelessness of winning by direct assault was forced to alter his strategy and employ the lengthy and arduous policy of seige tactics. This approach, while delaying the realization of the ultimate objective, and forcing the commander to "retreat" and formulate a new approach, ended, as Lenin claimed, "in complete victory, although it took a much longer time to achieve than was anticipated."79 The parallel to be drawn from this analogy by the Bolshevik readers was quite clear. If one were to substitute the world capitalist-imperialist system for Port Arthur and replace General Nogi with the forces of socialism, then one would have the policy of detente and the struggle against imperialism that Lenin was forced to wage in 1921. As Lenin, in summation of his historical metaphor, concluded:

If an army which had become convinced that it is unable to capture a fortress by direct assault said that it refused to leave the old positions and occupy new ones, refused to adopt new methods of solving its problems, one would say about. such an army that if it has learned to attack but has not learned to retreat at the dictates of certain severe conditions it will never win the war. Wars which began and ended with an uninterrupted victorious advance have never occurred in world history, or else they have been very rare exceptions.80

Lenin had earlier claimed that a "revolutionary epoch" was to his Party what "wartime is to an army," and that the revolutionaries must "extend the ranks of our army, increase it from peace to war strength, mobilize the reservists, call up those on furlough, organize new auxiliary corps, units, and services." 81 Now, it was incumbent upon this army to adopt new tactics and concern itself more with the pcacoful operations of a nation that was not at war and which could not use the 
tactics of direct and forceful assaults. It was necessary therefore, to "master all methods of warfare," and, if the Bolsheviks were able to do so, they, as Lenin claimed, will "certainly be victorious, because we represent the interests of the really advanced and really revolutionary class, even if circumstances do not permit us to use weapons that are most dangerous to the enemy, weapons that are most swift in dealing mortal blows." 82

If Lenin were unable to employ such lethal weapons, due to the weakness of his "army," he would have to formulate a new arsenal to forestall the impending attack by the imperialists. Lenin reasoned that the best way to effect this end was to make it economically unfeasible for the capitalist powers to attack by entangling them in a system of lucrative economic concessions. Thus, the policy of extending concessions to the West appeared to be a dual-edged strategy. It not only would provide Lenin with the industrial and technological assistance he needed for the task of economic reconstruction, but would also act as a buffer against any immediate imperialist aggression. As Lenin stated in a speech in November, 1920, the capitalists are still seeking pretexts for fighting and for destroying the Soviet state. However, "if they accept the proposals and agree to concessions it will be harder for them. On the one hand we will have the best corditions in the event of war; on the other hand, those who want to go to war will not agree to concessions." 83 It was logical for Lenin to assume that concessions, as an economic incentive for the capitalists, are "an economic and political argument against war," and that "from the point of view of the danger of a collision between capitalism and bolshevism, it must be said that concessions are a continuation of the war, but in a different sphere. 184 
This position, which is characterized by the paradox of building a military capacity with the aid of those countries against whom the capacity would be used, is best summarized in a dispatch sent by Chicherin to the Allied governments:

Since the capacity for resistance of the enemies which Soviet Russia has to fight depends entirely on the aid which they receive from the Allied Powers, and since these are, therefore, its only real adversaries, it is precisely to them that the Russian Soviet Government addresses its statements concerning the concessions which it would be possible to make with the object of putting an end to all conflicts with these
powers.85

Lenin then clearly delineated the second edge of this two-edged sword of detente; that of restoring the economic productivity destroyed by the war. According to a decree of the Council of People's Commissars, the "process of restoring the productive power of Russia, and with it of world-economy as a whole, can be greatly accelerated by means of attracting foreign public and municipal institutions, private undertakings, joint-stock companies, co-operative and workers'organizations of other states, to the business of extracting and working up the natural wealth of Russia." 86 Furthermore, these proposals were directed primarily toward the economically powerful United States, which possessed an "abundance of free capital," making it especially attractive for American capitalists to "exploit the natural wealth of the vast expanses of the RSFSR." 87

Lenin realized that Soviet Russia, in order to build a strong industrialized sector, (on which the socialist revolution was to be founded in the first place) required both the technology and widespread application of vast amounts of electricity. As Lenin claimed, "communism is the Soviet power plus the electrification of the whole country." Otherwise, he reasoned "the country will remain a small-peasant country, 
and that we must clearly realize." 88 The importance of the application of electricity as the stimulus for transforming the economic basis to one of large-scale industry was not underestimated by Lenin. As he claimed, "only when the country has been electrified, when industry, agriculture and transport have been placed on the technical basis of modern large-scale industry, only then shall we be finally victorious. "89 Lenin was quite aware of the fact, however, that the electrification goa] "without the help of foreign capital and means of production," could not be realized and, as he further stated, "to obtain assistance we must pay for it." 90 The United States was the most prosperous of the capitalist states and therefore, the logical choice as the most obvious source of economic assistance. Yet, as Lenin asked in a rhetorical fashion, "In order to enlist the Americans we must pay them: They are businessmen. And what are we to pay them with?" Lenin concluded that there was no choice as to the form of payment, since he could not pay for the much needed assistance with gold, ("we cannot throw gold about."), raw materials ("we have not yet fed all our own people"), or grain ("we are bargaining for every trainload of grain"):

What then shall we give? Rubbish? They have enough rubbish of their own. They say let us trade in grain; but we cannot give grain. We are therefore solving the problems by means of concessions.91

There are two interesting aspects of this concession policy of Lenin that have a direct bearing on his views towards detente. In the first place, Lenin argued that it was imperative to continue the fierce ideological and political struggle with the West during the era of peacefur coexistence. The economic arrangements and agreements made with the imperialists were but another manifestation of this unceasing war. It was important therefore, to insist that such agreements be 
negotiated and implemented "on terms carefulty formulated so as to ensure that the conditions in which these concessions are operated do not in any way conflict with the economic and social order of Soviet Russia." 92 Furthermore, these concessions would bring the Soviet republic in direct confrontation with the West, whose governments would be allowed to interject capitalist practices on Russian soil. Thus, Lenin would claim that "concessions are also a form of struggle, they are the continuation of the class struggle in another form, and under no circumstances are they the substitution of class peace for class war." 93 Concessions, in this light, were "nothing but a new form of war, " and while the Soviets had a "vast deal to gain from concessions," it was important to remember that these agreements merely highlighted and underscored "the military rivalry of two methods, two formations, two kinds of economy - communist and capitalist, we shall prove that we are the stronger." 94 Thus, it can be reasoned that detente of 1921 did not imply any de-emphasis of the class struggle. Rather, it incorporated an intensification of the ideological competition between the two competing socio-economic systems who, for the time being, had to coexist at close quarters. The second note of interest concerns the dupticity of Lenin in playing upon the cupidity of the enemy to whom these economic concessions would be granted. This point is it7ustrated by the case of a certain American industrialist Vanderlip who travelled to Moscow to negotiate a concession to "exploit oil, coal, and the fisheries of the Primorye Region and Kamchatka." 95 Vanderlip insisted on negotiating long-term contractual arrangements, during which time the Soviets could not exercise an option of buying them back. This was done despite protestations to the contrary by the Soviet representative 
A.I. Rykov. Unable to resolve the impasse, Rykov wrote to Lenin for instructions and received the reply, "you will concede a 50-year period for the concession." 96 Lenin, it can be argued, felt that the Soviet Union would not tolerate a fifty year period of capitalist intrusion, and based much of his ideological reasoning on the assumption that the capitalist system would soon be overthrown and destroyed. Yet, it was perfectly consistent with the Leninist strategy of detente to simultaneously strive for the inevitable collapse of capitalism in the not too distant future and concede long-term contractual guarantees in order to enlist immediate assistance.

It was equally justifiable for Lenin to augment his detente by entering into alliances with any and all imperialist states in order to use one nation, or bloc of nations, as a counterbalance to any potential threat by another group of imperialists. As Lenin claimed, "to carry on a war for the overthrow of the international bourgeoise, " a war which in Lenin's view was "a hundred times more difficult, prolonged, and complicated than the most stubborn of ordinary wars," and to "refuse beforehand to maneuver, to utilize the conflicts of interests (even though temporary) among one's enemies, to refuse to temporize and compromise with possible (even though transitory, unstable, vacillating and conditional) allies - is this not ridiculous in the extreme?" 97 Moreover, this policy of transitory socialist-imperialist alliances required a constant sense of shifting, changing, and adapting to the particular international environment at any given moment. To refuse to enter into such alliances with the "imperialist robbers" was, in Lenin's words tantamount to extremism: 
Is it not as though, when making a difficult ascent of an unexplored and hitherto inaccessible mountain, we were to refuse beforehand ever to move in zigzags, ever to retrace our steps, ever to abandon the course once
selected to try others??

From Lenin's perspective this policy had seen its practical adaptation as early as 1918 when the Soviets "shook hands with the French monarchist although we knew that each of us would readily hang his partner." 99 Yet, whether or not Lenin would have relished the "hanging of his partner," he knew that their interests coincided for the moment. Lenin next claimed that "to throw back the rapacious advancing Germans we made use of the equally rapacious counterinterests of the other imperialists thereby serving the interest of the Russian and the international socialist revolution. "100 However, such an alliance, in Lenin's view, was purely temporary in nature and served only one shortterm objective. Thus, Lenin, with no qualms, could state:

I would not hesitate a single second to come to the same
should an atgreement" with the German imperialist robbers,
it.101

An agreement of this kind would require the most inglorious and humiliating compromise which, as the "compromise" of Brest-Litovsk, would yield tremendous benefits; most noticeably the respite it would provide for the tasks of socialist construction. As Lenin depicted in analogical form:

Imagine that your automobile is held up by armed bandits. You hand them over your money, passport, revolver and automobile. You are spared the unpleasant company of the bandits. That is unquestionably a compromise... Our compromise with the bandits of German imperialism was a compromise of such a kind.102

These compromises and alliances might have appeared to the most radical of Bolsheviks to be unacceptable tactics, as they involved a surrender not only of principles and convictions but a good deal of 
territorial sovereignty as well. Lenin, however, saw these temporary alliances as a new form of struggle. If properly manipulated, they would prove to be invaluable assets to the cause of socialist proliferation in a global sense. As Lenin claimed, the Soviets must employ these new tactics, not for the purpose of reconciliation "but for the purpose of converting every and all form, new and old, into a weapon for the complete, final, decisive, and irrevocable victory of communism." 103 The teeth of this new weapon would be exposed in the form of exploiting the antagonisms of the imperialists. No matter how much the economic plan of concessions made it unfeasible to attack Soviet Russia, the imperialists, if not fighting among themselves, would eventually see the urgency of jointly destroying the center of a new and inimical form of government. This realization then became a canon of Leninist coexistence ideology:

...the fundamental thing is the rule which we have not only adopted theoretically, but applied in practice, and which will be our rule until the final victory of socialism throughout the world, that is: to exploit the contradictions and antagonisms between the two imperialisms, between the two systems of capitalist states, inciting them one against the other. So long as we have not won the entire world, so long as, from the economic and military point of view, we remain weaker than the rest of the capitalist world, so long shall we keep to that rule: we must know how to exploit the contradictions and antagonisms among the imperialists. 104

Lenin attached the utmost urgency to this topic of exploitation of antagonisms as he knew that the Soviet state was still in no condition to wage a life-and-death struggle in the military realm with any one of the advanced capitalist powers. He was also aware that the exploitation of imperialist contradictions as but one manifestation of his detente strategy, had yielded impressive results already, and to a large degree, had been the one variable that had preserved Soviet existence. As Lenill 
claimed, "had we not adhered to this rule, every one of us would have long ago been hanging from an aspen tree, to the satisfaction of the capitalists." 105 The most noticeable result of this strategy was the chance it afforded Lenin to launch his detente policy of 1918. Lenin let it be known that the success of that policy and the breathing spell it created, would serve as a model for Soviet tactics in 1921:

We took advantage of the hostilities between the two imperialisms in such a way that in the long run both lost. Germany got nothing from the Brest-Litovsk Peace except several million poods of grain,... but we gained time, in the course of which the Red Army began to be formed... That on which our antagonists counted, the rapid collapse of the Soviet power in Russia, did not eventuate. It was just this period, which history accorded us as a breathing space, 106 that we took advantage of in order to consolidate ourselves. 106

It now remained for Lenin to define exactly which antagonisms and contradictions his country had to exploit. In answer to his rhetorical question, "are there such fundamental disagreements in the contemporary capitalist world which we must exploit?", Lenin listed three areas of major concern to which the Bolsheviks must address themselves immediately. "The first, and the closest to us," according to Lenin, "are the relations between America and Japan. War is being prepared between them. They cannot live peacefully together in the Pacific." 107 It was imperative therefore, for the Soviet state, at the same time that it was wooing the United States to invest its capital in Russia, to do all in its power to exacerbate U.S.-Japanese tensions to the point that a major war would break out between them. If the Soviet republic, due to a number of internal problems, was forced to coexist with the "imperialist robbers," it would be tolerable only if they would slaughter each over. As Lenin asserted, "if we are obliged to tolerate such scoundrels as the capitalist thieves, each of whom is preparing to plunge a knife into 
us, it is our direct duty to make them turn their knives against each other. "108 The second area of antagonisms concerned the United States and the rest of the capitalist world. As Lenin asserted, "America is strong, everybody is now in her debt, everything depends on it, everybody hates America more and more, everything indicates that America cannot come to terms with other countries, because the most profound economic differences divide them, because America is richer than the others." 109 The third antagonism that had to be exploited and utilized for the Bolshevik cause centered on the Entente and Germany, a nation "crushed," as Lenin phrased it, by the Versailles treaty. In a bit of prophetic realism Lenin reasoned that Soviet Russia and Germany would soon come to terms and form a mutual pact. As Lenin deduced, Germany "cannot endure the Versailles treaty, and it must seek an ally against world imperialism, for although itself imperialist, it is being throttled." 110 This, in Lenin's view, was the only manner in which his country could break out of the oppressive ring of capitalist encirclement. It was the only way in which they could survive in an imperialist-dominated world, and the only means by which the Soviet state could prolong the invaluable respite that detente of 1918 had afforded it. This tactical consideration of Lenin was something that he clarified in no uncertain terms:

We are at present between two foes. If we are unable to defeat them both, we must know how to dispose our forces in such a way that they fall out among themselves; because, as is always the case, when thieves fall out, honest men come into their own.111

Throughout this entire period it was extremely important for Lenin to establish and maintain an outward manifestation of friendliness with the capitalist world. Lenin, as he claimed, needed the extension of the respite he was enjoying, and he knew that the Soviet regime could 
not endanger it by presenting a radical, bellicose, and revolutionary image to the West. It was clear to Lenin that he had no choice but to exploit and utilize the antagonisms and contradictions among the imperialists. These contradictions, as he reasoned, would prove stronger and more intense than the fundamental contradiction that existed between the capitalist system as a whole and the lone representative of world socialism. However, if the Soviet Union were seen as hostile, violent, and uncompromising the imperialists might very we 11 embark upon a course of action aimed at silencing forever this radical source of difficulty. Therefore, Lenin utilized the occasion of one of the first formal postwar conferences, in which the Soviets sat side by side with their capitalist adversaries, as a vehicle for formally launching the "new" posture of the Soviet peaceful businesslike image to the West. In his draft of a speech to be delivered at the opening session of the Genoa Conference in April, 1922, G.V. Chicherin had included a number of militant remarks regarding the inevitability of violent wars, the Soviet belief in violence, and the need for pursuing armed struggles. In a message passed on to Chicherin before he delivered his speech to the conference, Lenin made a number of drastic revisions, which he hoped would have a telling effect on the future course of capitalist-Soviet relations. Lenin eliminated any and all remarks that he felt might arouse suspicion on the part of the imperialists, and emphasized the fact that "having come here as merchants, we positively consider it our duty to give our fullest support to any attempts at a peaceful settlement of outstanding problems." According to Lenin "al1 mention of 'inevitable forcible revolution and the use of sanguinary struggle' must definitely be thrown out,... the words stating that our 'historic conception includes the use of forcible measures' 
should definitely be deleted... the words about our historic conception being definitely based on the inevitability of new world wars should be definitely deleted." In summation Lenin concluded:

Under no circumstances should such frightful words be used, as this would mean playing into the hands of our opponents. We should confine ourselves only to mentioning that the views of the Communists do not coincide with the views of such pacifists as the states we are beginning negotiations with...but that we consider it our duty, in order to achieve the economic agreement we are desirous of concluding, to do everything in our power for the broadest possible fulfillment of at least a certain part of this pacifist program. 112

This pacifist stance would only be the side of the Leninist strategy of detente that would be exposed to the view of the capitalists. While conceding to the economic wishes of the imperialist states, while entering into alliances and pacts with them, while clamoring for diplomatic recognition, and incessantly promising to refrain from interfering with their internal sovereignty, while pursuing a foreign policy of peace, Lenin was doing all in his power to both instigate wars among the capitalists and to incite domestic upheaval in all the nations of the imperialist system. Lenin, as he stated, was constantly waiting for a "spark" to kindle the conflagration of violence and revolt that would lead to the socialist transformation. Since there was no way of telling where this spark was, he realized that the Bolsheviks "must with the aid of our new communist principles set to work, to stir up all and sundry, even the oldest, mustiest and seemingly hopeless spheres, "in order to fulfill the tasks of "complete socialist victory."173 Lenin knew that the revolution in Russia had been achieved with the relative ease primarily because the capitalist and bourgeois elements in his native land had not become fully entrenched, due to the absence of the futr development of capitalism. The situation in the advanced capitalist 
states was quite different. The powerful bourgeois elements there had shown an obstinate and effective resistance to any change, thus making illegal, clandestine, surreptitious, and conspiratorial activity the only effective means of achieving success abroad. What is more, Lenin further lowered the "theoretical standards" of Marxism and set his sights on countries that had not even entered the capitalist stage of development. In view of the necessity of gaining allies during this era of coexistence, Lenin proceeded from the proposition that "with the aid of the proletariat of the most advanced countries, the backward countries may pass to the Soviet system and, after passing through a definite stage of development, to communism, without passing through the capitalist stage of development." 114 This is perhaps the essence of what detente really was for Lenin, and still is for contemporary Soviet leaders; a sophisticated and complicated deception based primarily on duplicity, cunning and actions aimed at luring the unwary nations of the capitalist system into disadvantageous circumstances that would hasten their ultimate demise.

It would be worthwhile, by way of summation, to outline the basic elements of the Leninist detente before moving on to the later stages of historical development. This is important because Lenin laid the foundation of this strategy in such a manner that subsequent Soviet leaders, in their interpretation and application of detente, would be making alterations in a strategy that had evolved and matured long before their assumption of power.

Immediately after seizing power in Russia, the Bolshevik Party, overcome with the euphoria of its success, concentrated its efforts at stimulating socialist upheavals in other countries, and most notably in Germany, based on an exploitation of the war weariness and general 
disillusionment of the masses. However, in 1918 Lenin, upon realizing that the Bolshevik revolutionary experience would not be duplicated in the near future, yearned for a breathing spell, a respite with which he hoped to achieve the goals of internal consolidation and economic reconstruction that he would need for a successful consummation of the impending imperialist-socialist war. This initial phase of detente, although marked by a good deal of diplomatic hostility and general unreceptiveness by the capitalist states, lasted until the winter of 1920 1921 when it became apparent that a longer respite was needed and that a concomitant modus vivendi had to be found. Reinforcing and intensifying his detente policy of 1918, Lenin adopted a live-and-let-live ethic, which coupled with economic concessions and a peaceful outward stance, would preclude an imperialist invasion. Such a policy would also prolong the much needed breathing spell, and allow the inherent contradictions and antagonisms of the capitalist system to intensify and hasten its ultimate collapse.

Detente can be seen therefore, as a self-serving strategy conceived, implemented, and developed by the Soviet regime. It is aimed, according to the Leninist formula, at effecting situations and environments that are advantageous to the Soviet cause of increasing its relative strength vis-a-vis the West. Furthermore, detente, although addressing itself to all nations of the "other" socio-economic system, has always considered the United States, the Soviet's most formidable economic and military adversary, as the one nation that must be defeated if peaceful coexistence is to achieve its full and complete victory. Detente is also a policy characterized by a very high degree of tactical flexibility, alteration, compromise, and adaptation. The policy of detente was designed 
to achieve prolonged periods of peace, whereby the weakened socialist state could gain strength. Yet, peace, as Lenin told us, is no more than a respite between wars, and a war, in whatever form it might take, was purely inevitable in Lenin's mind. Lenin realized that it was necessary to swallow his pride, to alter his principles and to endure the humiliation of living and working with the capitalists until his socialist state was strong and capable of challenging its enemies. Yet, he never lost faith in his conviction that "as soon as we are strong enough to defeat capitalism as a whole, we shall immediately take it by the scruff of the neck." \$15 In the final analysis, this can be seen as the ultimate concern of detente, the basic and inalterable principle on which the policy is based. As Lenin asserted in the last year of his life, this is a struggle against capitalism and "there can be not a shadow of doubt as to the final conclusion of the world struggle. In this respect, the final victory of socialism is fulty and unconditionaliy guaranteed."116 


\section{FOOTNOTES: CHAPTER IV}

I"Statement Conveying Recognition of the Provisional Government by the United States, and the Provisional Government's Reply, March 22, 1917." C.K. Cumming and Walter W. Pettit, eds., RussianAmerican Relations, March, 1917-March 1920: Documents and Papers,

2 "Note from President Wilson to the Russian Government, May 26, 1919," Ibid., pp. 23-24.

${ }^{3} V . I$. Lenin, "The Two Tactics of Social Democracy in the Democratic Revolution," July 1905, Selected Works, (New York: International Publishers, 1943), Vol. III, p. 75.

${ }^{4} V . I$. Lenin, "The Development of Capitalism in Russia, 1896-1898," Selected Works, Vol. I, pp. 203-212.

${ }^{5}$ V.I. Lenin, "Report on the Current Situation," May 7, 1917, Selected Works, Vol. VI, p. 99.

${ }^{6}$ V.I. Lenin, "What Is To Be Done? Burning Questions of the Movement," February, 1902, Selected Works, Vol. II, p. 114.

7 Ibid., p. 155.

${ }^{8}$ V.I. Lenin, "The Urgent Tasks of Our Movement," December, 1900, Selected Works, Vol. II, p. 13. p. 101 .

9V.I. Lenin, "What Is To Be Done?" Selected Works, Vol. II,

$10^{1}$.I. Lenin, "The Right of Nations to Self-Determiration," February-May, 1914, Selected Works, Vol. IV, p. 291.

11 V.I. Lenin, "Our Program," 1899, Collected Works, (Moscow: Progress Publishers, 1964), p. 212.

${ }^{12}$ V.I. Lenin, "The Tasks of the Proletariat in Our Revolution," April 23, 1917, Selected Works, Vol. VI, p. 73.

p. 46 .

${ }^{13}$ V.I. Lenin, "What Is To Be Done?" Selected Works, Vol. II,

14 "Decree on Peace, Passed by the Second Al1-Russian Congress of Soviets of Workers', Soldiers', and Peasants' Deputies, "November 8, 1917, Jane Degras, ed., Soviet Documents on Foreign Policy, Vol. I., 
1917-1924, (London: Oxford University Press, 1951), p. 1.

15 "Statement by Lieutenant-Colonel Kerth to General Dukhonin," November 27, 1917, Russian-American Relations: Documents and Papers,
p. 53 .

16 "Letter from General Judson to the Chief of the Russian General Staff," November 25, 1917, Ibid., p. 47.

17 "Statement by Allied Military Attaches at the Russian Staff Headquarters," November 23, 1917, Ibid., p. 49.

18 By his own admission, Lenin's position stating that the BrestLitovsk treaty should immediately be signed was supported by only onefourth of the Party's high ranking functionaries. Half the functionaries, according to Lenin, favored pursuing a "revolutionary war," while the remaining fourth were in favor of Trotsky's famous "neither war, nor peace" dictum. See V.I. Lenin, "Afterword to the Theses on the Question of the Immediate Conclusion of a Separate and Annexationist Peace," Collected Works, Vol. XXVI, p. 451.

19 V.I. Lenin, "The Collapse of the Second International," June, 1915, Selected Works, Vol. V, p. 179.

${ }^{20}$ V.I. Lenin, "Proposals Submitted by the Central Committee of the R.S.D.L.P. to the Second Socialist Conference," Collected Works, Vol. XXII, p. 169.

${ }^{21}$ V.I. Lenin, "Imperialism: The Highest Stage of Capitalism," Selected Works, Vol. V, p. 9.

${ }^{22}$ V.I. Lenin, "The Tasks of the Youth Leagues," 1920, Selected Works, Vol. IX, p. 475.

${ }^{23}$ V.I. Lenin, "Letter to Maxim Gorky," December, 1913, Selected Works, Vol. XI, p. 679.

${ }^{24}$ V.I. Lenin, "State and Revolution," 1917, Selected Works, Vol. VII, p. 143.

\section{Ibid., p. 37.}

${ }^{26}$ Ibid. , p. 14.

${ }^{27}$ V.I. Lenin, "A Letter to American Workers," August 20, 1918, Collected Works, Vol. XXVII, p. 63.

$28^{\prime \prime}$ Cable sent by President Wilson to the Al1-Russian Congress of Soviets at Moscow, March 14-16, 1918, Russian-American Relations: Documents and Papers, p. 88.

\section{9 "Resolution of the Fourth All-Russian (Extraordinary)} Congress of Soviets in Reply to President Wilson," March 14, 1918, Soviet Documents, Vol. I, p. 63. 
${ }^{30}$ Adam B. Ulam, Expansion and Coexistence: The History of
Soviet Foreign Policy, 1917-1967, (New York-Washington: Frederick
A. Praeger, 1968), pp. 126-129.

${ }^{31}$ George F. Kennan, Russia and the West Under Lenin and Stalin,

${ }^{32} \mathrm{~V} . I$. Lenin, "Theses on the Question of a Separate Peace," 1918, Collected Works, Vol. XXVI, p. 448.

33 Ibid.

${ }^{34}$ V.I. Lenin, "Political Report of the Central Committee, at the Seventh Congress of the R.C.P.(B), March 7, 1918, Collected Works, Vol. XXVII, p. 98.

${ }^{35} \mathrm{~V} . \mathrm{I}$. Lenin, "Theses on the Question of a Separate Peace," 1918, Collected Works, Vol. XXVI, pp. 442-443.

${ }^{36}$ Ibid., p. 443.

37

Ibid.

38

Ibid.

${ }^{39} \mathrm{~V} . \mathrm{I}$. Lenin, "The Immediate Tasks of the Soviet Government," 1918, Collected Works, Vol. XXVII, p. 238.

${ }^{40} \mathrm{~V} . I$. Lenin, "Theses on the Question of a Separate Peace," 1918, Collected Works, Vol. XXVI, pp. 447-448.

${ }^{41}$ G.V. Chicherin, "Report on Soviet Foreign Policy to the Fifth Al1-Russian Congress of Soviets," July 4, 1918, Soviet Documents, Vol. I, p. 83.

42 Ibid. , pp. 83-85.

43 Ibid., p. 85 .

${ }^{44}$ V.I. Lenin, "Letter to American Workers," 1918, Collected Works, Vol. XXVIII, p. 75.

${ }^{45}$ G.V. Chicherin, "Report to the Congress," Soviet Documents, Vol. I, P. 84 .

46" Note From Trotsky, Commissar For War, To Colonel Robins For Transmission to the American Government Concerning the Attitude of the Allies if the Soviet Congress Should Refuse to Ratify the BrestLitovsk Treaty," Ibid., p. 56.

47"Extracts From A Statement By Trotsky On The Internationa] Situation At the Central Executive Committee, "November 21, 1917, Ibid., p. 7. 
48 "Plan for Russian-American Commercial Relations, Sent by Lenin to Colonel Robins," May 14, 1918, Russian-American Relations:
Documents and Papers, pp. 205-206.

49 Ibid., p. 209.

${ }^{50}$ Ibid., pp. $211-212$.

51 "Extracts From A Speech by Lenin on Foreign Affairs to the Central Executive Committee," May 14, 1918, Soviet Documents, Vol. I, p. 78.

52 Ibid., p. 79.

53 Ibid., pp. 78-79.

54 Ibid., p. 79.

${ }^{55}$ Leonid Strakhovsky, Intervention at Archangel (Princeton: Princeton University Press, 1944), p. 89.

${ }^{56}$ George F. Kennan, Soviet-American Relations, 1917-1920, Vol. II (Princeton: Princeton University Press, 1958), p. 17.

57 Leonid Strakhovsky, The Origins of American Intervention in North Russia, 1918, (Princeton: The Princeton University Press, 1937), p. 43.

58 William S. Graves, America's Siberian Adventure (New York: Peter Smith, 1941), p. 354.

59 "Official Announcement Issued at Washington, August 3, 1918," Russian-American Relations: Documents and Papers, p. 238.

${ }^{60}$ George Vernadsky, A History of Russia (New York: Praeger Publishers, 1968), p. 271.

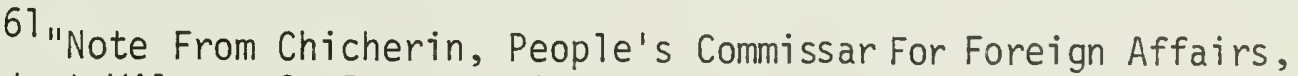
To President Wilson, On Intervention And The League of Nations," October 24, 1918, Soviet Documents, Vol. I, p. 114.

${ }^{62} \mathrm{~V} . \mathrm{I}$. Lenin, "The International Situation and the Fundamental Tasks of the Communist International, "July 19, 1920, Selected Works, Vol. X, p. 188.

${ }^{63}$ E. Malcolm Carroll, Soviet Communism and Western Opinion, 1919-1921 (Chapel Hi11: University of North Carolina Press, 1965), p. 194.

64 "Speech by Lenin to the Central Committee," May 14, 1978, Soviet Documents, Vol. I, p. 78. 
65 "Resolution of the Seventh Congress of the Russian Communist Party," Ibid., pp. 61-62.

${ }^{66}$ V.I. Lenin, "Speech Delivered at a Meeting of Cells'

Secretaries of the Moscow Organization of the R.C.P. (B), "November 26, 1920, Selected Works, Vol. VIII, p. 283.

Vol. IX, p. 38

67V.I. Lenin, "The Party Crisis," January 19, 1921, Ibid.,

68 V.I. Lenin, "Left Wing Communism: An Infantile Disorder," April, 1920, Selected Works, Vol. VIII, p. 118.

${ }^{69} \mathrm{~V} . \mathrm{I}$. Lenin, "The Importance of Gold Now and After the Complete Victory of Socialism," November 5, 1921, Selected Works, Vol. IX, p. 299.

70

Ibid.

${ }^{71}$ Ibid.

${ }^{72}$ V.I. Lenin, "Political Report of the Central Committee to the Eleventh Congress of the Russian Communist Party (Bolsheviks)," Ibid., p. 347.

73 V.I. Lenin, "Left Wing Communism," Ibid., Vol. VII, p. 138.

74 V.I. Lenin, "The New Economic Policy," October 29, 1921, Selected Works, Vol. IX, p. 288.

${ }^{75} \mathrm{~V}$.I. Lenin, "Speech to the Seventh Congress of the Russian Communist Party on the Brest-Litovsk Peace," March 7, 1918, Soviet Documents, Vol. I, p. 58.

${ }^{76}$ V.I. Lenin, "On Cooperation," January 6, 1923, Selected Works, Vol. IX, p. 408.

77 V.I. Lenin, "The Fourth Anniversary of the October Revolution," October 14, 1921, Ibid., Vol. VI, p. 508.

${ }^{78}$ Ibid.

$79 \mathrm{~V}$.I. Lenin, "On the Right of Nations to Self-Determination," October, 1921, Ibid., Vol. IX, p. 278.

${ }^{80}$ Ibid., p. 290.

81 V.I. Lenin, "New Tasks and New Forces," March, 1905, Ibid., Vol. III, p. 435.

${ }^{82}$ V.I. Lenin, "Left Wing Communism," Ibid., Vol. VII, p. 138. 
${ }^{83}$ V.I. Lenin, "Speech Delivered at a Meeting of Cell's

Secretaries of the Moscow Organization of the R.C.P. (B), "November 26, 1920, Selected Works, Vol. VII, p. 297.

${ }^{84}$ Ibje.

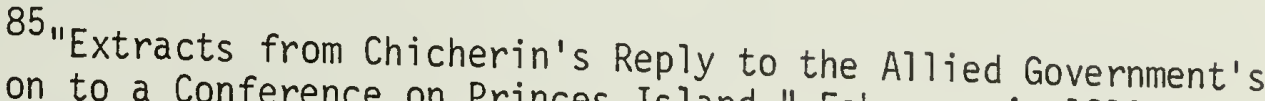
Invitation to a Conference on Princes Island, "February 4, 1919, Soviet Documents, Vol. I, p. 138.

86 "Decree of the Council of People's Commissars on the General Economic and Legal Conditions for Concessions," Ibid., p. 220.

87 Ibid.

88 V.I. Lenin, "The Work of the Council of People's Commissars," December 22, 1920, Selected Works, Vol. VII, p. 275.

${ }^{89}$ Ibid.

p. 294.

${ }^{90}$ V.I. Lenin, "Speech to R.C.P. (B)," November 26, 1920, Ibid.,

91 Ibid.

92"Chicherin's Reply," February 4, 1919, Soviet Documents, Vol. I, p. 138.

93 V.I. Lenin, "The Collapse of the Second International," April 21, 1921, Selected Works, Vol. IX, p. 182.

94 V.I. Lenin, "Speech to R.C.P. (B)," November 26, 1920 , Ibid., Vol. VII, p. 294.

${ }^{95}$ The Soviet version of this entire episode is presented at length in the "Notes" to Volume 44 of V.I. Lenin, Collected Works (Moscow: Progress Publishers, 1970), especially note 440, p. 551, and note 468, p. 557.

${ }^{96}$ V.I. Lenin, "Note to A.I. Rykov," October 6, 1920, Collected Works, Vol. XLIV, p. 442.

p. 111 .

97V.I. Lenin, "Left Wing Communism," Selected Works, Vol. VII,

98 Ibid.

${ }^{99}$ V.I. Lenin, "Letter to American Workers," 1918, Collected Works, Vol. XXVIII, p. 74.

100 Ibid.

101 Ibid. 
${ }^{102}$ V.I. Lenin, "Left Wing Communism, " Col lected Works,
Vol. VII, p. 75 .

103 Ibid.

${ }^{104}$ V.I. Lenin, "Speech to the R.C.P. (B)," November 26, 1920, Ibid., Vol. VII, p. 279.

105

Ibid.

106

Ibid., p. 281.

107 Ibid., p. 284.

108 Ibid., p. 288.

109

Ibid.

110 Ibid.

111 Ibid., p. 284.

112 This message was dictated by Lenin on the telephone to Molotov and was transcribed on type by his secretary on March 23, 1922. It was subsequentily excluded from any collection of Leninist materials until it appeared as a "New Document" published in Pravda on April 22, 1964. The present reference, and the one cited here, is V.I. Lenin, "Ammendments and Remarks to the Draft Declaration of the Soviet Delegation at the Genoa Conference," Collected Works (Moscow: Progress Publishers, 1969), Vol. XLII, p. 410.

p. 142 .

113 V.I. Lenin, "Left Wing Communism," Selected Works, Vol. VII,

114 V.I. Lenin, "Report of the Commission on the National and Colonial Question," Second Congress of the Communist International, July 26, 1920, Ibid.

115 V.I. Lenin, "Speech to the R.C.P.(B)," November 26, 1920, Ibid., Vol. VII, p. 282.

116 V.I. Lenin, "Better Less, But Better," March 1923, Collected Works, Vol. XXXIII, p. 458. 


\section{H A P T E R V}

THE POLICY OF DETENTE AS IMPLEMENTED BY BREZHNEV

The Soviet Union, during the tenure of Leonid Brezhnev has, as the following evidence will indicate, employed the process of detente, as originally designed by Lenin. However, as will be shown, the present regime has incorporated some basic changes in the eight-part detente strategy that was initially created in 1918. Some of these revisions were inherited by the present leadership from the predecessors of Brezhnev. A brief overview of these regimes is therefore, in order, so that the historical and ideological continuity of detente from Lenin to Brezhnev, from 1918 to the present, can be more clearly shown.

\section{The Stalinist Perception of Detente}

Historical evidence indicates that the policy of detente that was developed by Lenin was both recognized and continued by Stalin. Stalin both conceded the existence of detente and acknowledged its now long-term nature. In his report at the 14th Congress of the C.P.S.U. in 1925, Stalin claimed:

There is now, as it were, a kind of "peaceful cohabitation" between the land of the soviets and the lands where capitalism prevails. What seemed at first as if were only to be a short breathing space after the war, has become a whole epoch of comparative repose. That is why there is an equilibrium of forces; that is why there is a period of "peaceful co-habitation" between the bourgeois world and the proletarian world. 1

It then became important for stalin to ensure the fact that this 
"co-habitation" would continue, for the purpose of further strengthening the Soviet state. In 1925 therefore, Stalin informed party members that the first task of the party was to "carry on the struggle against new wars, the struggle to maintain peace and to secure the persistence of the so-called normal relationships towards capitalist countries." 2 It can be reasoned that the major motivating factor for the maintenance of peaceful relations with the West in the late 1920's was identical to that of 1918. Stalin was still forced, by the devastation of the war, to do all that he could to restore the Soviet economy to its pre-war levels. This effort, pursued within the confines of the five year plan, necessitated, in Stalin's mind, a detente relationship with the West. In the words of the then Vice-Commissar for Foreign Affairs, Maxim Litvinov:

The new, additional, and wholly objective proof of our peaceful aspirations is provided by our five year plan; to carry out our plan we must strive for conditions of uninterrupted peace. It should be clear to everybody that it would be insane to start out on this gigantic plan... if at the same time we had not resolutely determined...not to allow the peace to be broken. ${ }^{3}$

Upon his appointment to the position of Commissar for Foreign

Affairs, Litvinov expanded on the philosophy of detente:

We have to build socialism in our own country, surrcunded by capitalist countries occupying five-sixths of the earth's surface...we are therefore trying to discover and put into operation methods for the peaceful co-existence of the two social systems. We have, and shall have in the future, to make the greatest efforts to combat the aggressive tendencies of certain capitalist groups making for the creation of constant disputes and conflicts between the two systems; therefore, these efforts will be directed to the consolidation and maintenance of peace among the nations. 4

The manner in which this maintenance of peace was developed continually shifted throughout Stalin's reasonably long tenure in power. Yet, throughout a period in history that saw local wars, a world war, alliances, communist expansion, socialism in one country, conlainment, 
encirclement, purges, and a host of other diverse policies and actions, the underlying current of detente was not lost. This is not to say that Stalin was motivated solely by ideological concerns. Certainly, there is evidence to show that Stalin was pragmatic in his development of Soviet foreign policy. In fact, many of the policies outlined above can be seen as showing a blend of ideological and pragmatic determinants on Stalin's part.

It was mentioned above that the separation of short-term, pragmatic, or national interest objectives from long-term ideological objectives might lead one to conclude that the Soviet Union is motivated solely by concerns of national interest to the exclusion of ideology. A brief glance at two (2) foreign policy developments during Stalin's rule might clarify this point in regard to the foreign policy of Stalin. In the first place, it can be argued that Stalin's military alliance with the west during World War II was pragmatic in nature in that it addressed the needs of survival for the Soviet state in the face of the invasion by Nazi Germany. However, it is also reasonable to assume that stalin, who did not abandon the goal of the worldwide victory of socialism, could not achieve this goal if the Soviet Union were permanently crushed by Hitler. Secondly, in the aftermath of World War II, and in light of the military and territorial victories enjoyed by the U.S.S.R., albeit with a staggering loss of Soviet lives, Stalin reverted to pre-war animosities with the West. Stalin's "two camp thesis" of 1946, among other pronouncements, re-affirmed the Soviet belief that the world was still divided into two opposing camps with totally irreconcilable ideologies and socio-economic structures, with one destined to eventually triumph over the other. Il can be argued that Stalin was motivated in breaking the altiance with 
the West by pragmatic concerns of Soviet national interest, i.e. the need to be intransigent in consolidating Soviet gains in post-war Europe and to establish "friendly" nations there so as to protect the Soviet European flank against any future attack, to protect Soviet security on its borders, etc. In light of a central thesis of this study, it can also be reasoned that Stalin had favorably addressed the cause of achieving the eventual worldwide victory of socialism by altering the correlation of world forces to the benefit of socialism. Whether inspired by pragmatism or dogmatism, Stalin, as Vojtech Mastny argues in his Russia's Road to the Cold War: Diplomacy, Warfare, and the Politics of Communism, 1941-1945, can be assumed to bear the responsibility for the disintegration of the wartime alliance and the creation of the cold War. Stalin's designs and the incompetence of the leaders of the West in dealing with Stalin, as argued by Professor Mastny, served as the major determining factors for the consolidation of Soviet gains and the emergence of the Cold War. 5

The point to be made here is that Stalin, as Lenin before him and Khrushchev and Brezhnev after him, did not abandon the long-term goal of Marxist-Leninist ideology, the eventual worldwide triumph of socialism. Thus, it can be argued that Stalin was not devoid of any theoretical motivations, ${ }^{6}$ and that his short-term pragmatic objectives were components of a much larger long-term ideological goal that the U.S.S.R. has not relinquished. 7

The eight components of Leninist detente, when analyzed against the background of Stalin's rule, would provide the best means of assessing the continuity of detente through 1953.

Stalin, as did Lenin, required a continued breathing spel1, a 
respite by which he could consolidate the domestic problems confronting the Soviet government. In many ways, it can be argued that Stalin created his own domestic concerns that necessitated a position of detente with the West. Forced collectivization, rapid industrialization, and the blood purges consumed a good deal of the country's attention, if not its basic strength. Much of Stalin's concerns were, of course, beyond his control. The inherited ravages of World War I and the eventful destruction of World War II placed Stalin in a position of constantly consolidating internal strength.

The Soviet Union remained an "oasis" in a sea of capitalists during Stalin's early years in power, owing to the continued failure of the socialist revolution in Europe, particularly in Germany. Yet, at his death the East-West balance of forces had tilted to the side of the socialist camp. The second Leninist variable had therefore, been decreased as a source of concern for the Soviets who would now be free to render "assistance" to the worldwide socialist movement.

Stalin greatly improved, but did not eliminate, the military imbalance that favored the United States. In the transition from the conventional to the nuclear age of weaponry, Stalin consistently found a quantitative and qualitative superiority enjoyed by his imperialist adversary. Hence, Stalin was always forced to concentrate his efforts at eliminating the military superiority of the United States, which, it can be reasoned, had effectively precluded any Soviet-inspired confrontation between the two.

Stalin fully adhered to the belief that a final and fatalistic confrontation between the East and West was an historical inevitability. In fact, Stalin felt that the growing might of the Soviet Union, in the 
face of renewed crises and intensified antagonisms within the imperialist camp, would hasten this eventual confrontation.

Threats of intervention and armed assaults against the U.S.S.R. were also seen by Stalin. It can be argued that imperialist crises, the rise of Nazism in Germany, the Great Depression, and the capitalist fear and mistrust of the Soviet Union all contributed, in Stalin's mind, to the belief that an anti-Soviet alliance and eventual invasion were imminent.

Stalin fully realized the need for, and reaped the benefits of, economic assistance and trade rerations with the West. It was equally as necessary for Stalin as it was for Lenin to secure the tools of production and scientific and technological expertise in industry and agriculture from the West.

Stalin was also mindful of the need to exploit rivalries and antagonisms within the imperialist camp so as to preciude any permanent reconciliation among his adversaries that might eventually evolve into a strong anti-Soviet alliance. It apparently was necessary for Stalin to walk a fine tightrope on this point, however. To stir up many animosities and tensions could lead to another general war, an action that the Soviets wanted to avoid at all costs. It can be reasoned therefore, that Stalin was quite satisfied with the hostilities that existed between the nations of the West, until such time as they laid the groundwork for a global war that would certainly involve the U.S.S.R. However, Stalin was not only a pragmatist, but a good pupil of Lenin as wel1, and Lenin had shown the need to come to an agreement with one imperialist "dog," or group of "dogs," to avoid being decimated by the rest of the pack. Hence, Stalin shifted from complacency with the imperialist crises, to an 
anti-Hitler rapprochement of sorts, to the Nazi-Soviet non-aggression pact, to the anti-Hitler wartime alliance, and finally back to the anti-Western "two camp" Cold War posture.

Historical evidence indicates that the most important of the eight components of Lenin's detente remained intact through Stalin's reign. The socialist system would inevitably conquer its antithesis and create a new world order of socialism. Thus, it can be argued that the ultimate defeat of the West and the final victory of the proletariat was not a smokescreen for Soviet exparisionism or a ritualistic or manipulative justification for Stalin's actions; it was rather, an objective of Stalin's foreign policy.

By way of summary it can be stated that Stalin maintained the core of Lenin's detente but made some subtle shifts with the changing historical environment. The Soviet Union was now stronger militarily, more stable economically, far more secure internally, and more powerful internationally as the head of a system of socialist states.

\section{Khrushchev's Perception of Detente}

The legacy inherited by the Soviet leadership upon the death of Stalin can be seen as being far more enviable than that which Lenin bequeathed to his successor. With the situation of the U.S.S.R. in a near stable position, the new leadership saw no immediate need to radically alter the policy of detente with the United States. In fact, in his eulogy at Stalin's funeral Georgi M. Malenkov, the assumed heir to Stalin's throne, first sanctified the name of "the great genius of mankind," and "the great thinker of our epoch," then gave the official Bolshevik blessing to the policy of detente: 
The peoples of all lands know Comrade Stalin as the great standard bearer of peace. Comrade Stalin directed the great force of his genius toward championing the cause of peace for the peoples of the countries... The Soviet Union has waged and is waging a consistent policy of preservation and strengthening of peace, a policy of international cooperation and development of business relations with a 17 countries, a policy based on the Lenin-Stalin premise of the possibility of prolonged coexistence and peaceful competition of two different systems, capitalist and socialist. 8

It has been said, however, that all things are subject to change, and in the Soviet Union these changes often assume a drastic if not metamorphic nature. Stalin would soon lose his position in history as a "great genius," as "the great thinker" who served as a comrade in arms with Lenin, and as a great contributor to the holy scripture of MarxistLeninist ideology. Malenkov would never succeed in replacing Stalin as the acknowledged head of the U.S.S.R. In each case, Nikita Khrushchev proved to be the major catalyst, as he both disposed of Malenkov as a serious political challenger and disposed of the memory of Stalin and his policies.

Unlike Stalin and Malenkov, however, detente would not become an "unpolicy" under Khrushchev. Stalin was "de-stalinized," the "anti-party group" was purged, and Soviet foreign policy changed its course sometimes subtiy and sometimes drastically during the Khrushchev reign. Yet, while Khrushchev altered many of the basic guidelines for Soviet foreign policy, he did not eliminate detente as the cornerstone of Soviet activity in the international forum. Indeed, with the many variations added by Khrushchev, it can be argued that detente became a very strong policy that served as the catalyst for all aspects of Soviet foreign policy.

While Khrushchev did not eliminate detente, he did give the policy a thorough facelift. The Khrushchev application of detente might best 
be judged against Lenin's eight criteria.

First, it can be argued that Khrushchev no longer needed the breathing spell that detente had afforded his predecessors. At least Khrushchev did not require this respite as desperately as Lenin and Stalin since the Soviet government and the C.P.S.U. had consolidated their strength rather well and the country had overcome the awesome domestic problems that had confronted it. Khrushchev may not have been faced with a major post-war reconstruction effort, a civil war, or general havoc, but his own political struggles, purges, an attempted ouster, "thaws," and economic miseries appear to have all contributed to an environment that necessitated peaceful relations with the West.

Khrushchev inherited an international environment that saw the U.S.S.R. far-removed from the position of an "oasis," as the "socialist transformation" had taken place in a number of countries. This evolution may have been brought to these nations by the Red Army, Chinese peasantsoldiers, and Cuban guerillas as much as by any principles of MarxismLeninism. Nonetheless, the socialist-capitalist balance of forces now favored the socialist camp and Khrushchev was at the helm of a monolithic, and eventually fragmented, communist world. This, and Khrushchev's incessant, though peaceful, drive to further augment the ranks of the "friendly and fraternal" commonwealth of nations provided a renewed fuel for detente.

The continued East-West military imbalance that had plagued Lenin and Stalin continued to haunt Khrushchev as we11. The arena for this military competition had shifted from the conventional to the strategic realm and Khrushchev, it can be argued, constantly found the technological superiority of the United States in this area to be a 
deterrent to any excessively hostile Soviet action. In an apparent attempt to lessen the impact of his nuclear inferiority Khrushchev unleashed his short-lived "sputnik diplomacy" and his short-sighted Cuban missile venture. The missile "gap" was shown to be on the Soviet side, strategic parity was never achieved, and continued peace with the United States remained a necessity.

The major innovation that Khrushchev added to the detente formula, in this writer's view, had to do with the theory of war and violent means to achieve revolutionary ends. Unlike Lenin who saw wars and violent revolutions as necessary components of revolutionary change, Khrushchev implemented the strategies of "peaceful transition to socialism," "non-violent roads to power," and the "non-capitalist path of development," among others. In addition, Khrushchev radically altered the Leninist concept of the inevitable cataclysmic clash between the Soviet state and world capitalism. Arguing from his new premise of gradual and peaceful erosion of the capitalist system, Khrushchev reasoned that wars between the two camps were no longer "fatalistically inevitable." Moreover, wars of any kind that might provoke an East-West, or more importantly a U.S.-Soviet, confrontation were no longer seen as viable uptions for the U.S.S.R. In their place Khrushchev would use economic, diplomatic, and peaceful efforts to attract the non-socialist, and especially Third World nations, away from the American sphere of influence.

The prospects of an anti-Soviet alliance and invasion had diminished in one regard as the growing military might of the Soviet Union coupled with the ever-expanding socialist camp would serve, in the Soviet view, as a viable deterrent to such intentions. On the other hand, it was reasoned that these same factors could serve to provoke a 
reckless attempt by the capitalist-imperialist system to thwart the threatening and unstoppable march of communism. In short, the rationale for the phobia had changed but the fear remained.

The reliance on favorable economic relations with the West remained a viable tactic for Khrushchev whose "hare-brained schemes," according to his successors, may have done as much to create as to solve the many problems facing the Soviet economy. Advantageous trade agreements, foreign credits, and an influx of Western technology were still vital aspects of the Soviet policy of peaceful relations. An inordinate share of the Soviet wealth was being allocated to military and space-related expenditures, leaving precious little to appropriate to other commodities. It was incumbent upon Khrushchev therefore, as it was for his predecessors and would be for his successors, to turn to the West for economic assistance.

It remained quite necessary, from Khrushchev's perspective, to exploit the inherent contradictions and antagonisms within the imperialist camp, although the rationale was again changed. The "divide and conquer" syndrome was no longer primarily seen as a means for postponing the antiSoviet alliance (although the possibility of such was still conceivable in Khrushchev's mind) or for providing the catalyst for open warfare among the imperialists. Rather, it can be shown that this strategy now provided the possibility to breach the capitalist front and open opportunities for American-controlled, non-aligned, and Third World nations to move into the "non-capitalist" Soviet sphere of influence.

Lastly, the Leninist view of the ultimate victory of socialism and the concomitant demise of capitalism-imperialism remained as the main objective of detente throughout the Khrushchev years. Yet, Khrushchev had taken Lenin one step further in regard to the tactical 
means by which to achieve this final goal. Lenin had told us in his a forementioned analogy that the best way to capture Port Arthur was to use the time-saving direct approach, i.e., a frontal military assault. When that fails, however, Lenin preached the time-consuming graudal approach, i.e., a long military siege. Khrushchev added a new wrinkle to Lenin's parable and advocated the much longer incremental and peaceful approach that, under the right conditions, would not even require an army.

Detente had now come full circle. Conceived as a desperation policy aimed at buying time, detente had now become the means by which Soviet/communist goals could be realized. Detente was originally a defensive ploy, a means by which a respite, a breathing spell could be bought so that the Soviet state could prepare itself for the inevitable military confrontation with the United States and the rest of the capitalist system. Khrushchev transformed detente into an offensive strategy, a policy that would allow the U.S.S.R. to tilt the global correlation of forces heavily, if not totally, to the Soviet sphere and throughout it all never provoke an American military response.

Yet, the detente formula was not complete, in this writer's view, as the Soviets had yet to achieve thermonuclear parity or superiority. It remained for the successors of Khrushchev to add this last variable and revitalize detente as we know it today.

\section{The Brezhnev Adaptation of Detente, 1972-1976}

The purge of Khrushchev in 1964 brought the "collective leadership" of Brezhnev, Kosygin, and Podgorny to the helm of Soviet power. By relative comparison to their predecessor the three new Soviet 
leaders gave some the impression of being far less ambitious, aggressive, and unpredictable. In fact, the new triumvirate was often stigmatized as being overly bureaucratic, slow to move, and as lacking revolutionary zeal. The fact that there were three apparent co-equals did much to foster the belief that the new bureaucratic leadership might well herald a period of status quo, and certainly a period of reduced Soviet aggressiveness in the international arena. After all, none of the three had actively participated in the Bolshevik revolution and could not be expected to produce the inspiration or charisma that was Lenin's. Certainly, the new leadership could not, in the view of most observers, achieve the level of personal dominance and complete control possessed by Stalin. Even Khrushchev's unique brand of charisma and party dominance may have seemed to be beyond the reach of the new uninspiring Soviet leadership.

It became fashionable therefore, to look upon the new Soviet regime as a rather unexciting group that would pose no serious immediate threat to American interests abroad, and one that would not embark on any provocative or terribly hostile foreign policy ventures. It is understandable that this view was espoused in the early days of the new Brezhnev, Kosygin, and Podgorny regime, as indeed the new collective leadership did not appear to be extremely dynamic by any standard. That such a view persisted for a number of years however, both underscores the misinterpretation of the Brezhnev style of detente, in this writer's view, and pays a good deal of tribute to the effectiveness of detente as a functional tool of Soviet foreign policy under Brezhnev.

Detente, as will be reasoned below, did not become a passive policy under Brezhnev, and Soviet foreign policy did not become stagnated 
with the changing of the guard in the Kremlin. Rather, it will be shown that detente became a far more ominous weapon in the Soviet foreign policy arsenal as the new leadership embarked upon a more forceful course of relations with the West. It is important that this point be emphasized. Khrushchev, as historical evidence indicates, had presented the West with a very direct, and oftentimes threatening posture, as visibly manifested in Berlin and Cuba. The response from the United States was predictably strong and tended to thwart any major Soviet aspirations that threatened American interests. Consequently, Khrushchev may not have achieved tremendous foreign policy successes as the American government easily justified a firm response to an easily identified enemy who had promised Americans that their grandchildren would grow up under communism.

It can be reasoned that Brezhnev realized that it was counterproductive to maintain the United States in a state of total preparedness against Soviet aggression and, at the same time to achieve any measure of success in foreign policy. To present a constant and ominous threat to the United States, whose economic, military, scientific, and technological resources far exceeded those of the U.S.S.R., would, in this view, permanently drain the weak Soviet economy and perpetuate the status quo in the relative position of each country. Thus, it was necessary for Brezhnev to reduce the visible threat and replace tanks in Berlin, missiles in Cuba, and "sputnik diplomacy" with cultural exchanges, economic cooperation, and Soyuz-Apollo space ventures. Brezhnev, rather than promising communism for Americans' grandchildren, chose to speak on American television about "greetings," "friendly feelings" and a commitment toward "improving relations between our countries and strengthening universal peace." 9 
Thus, to play on the naivité of the enemy could, in Brezhnev's mind, yield tremendous results. The more threatening a posture presented to the United States, the more direct and unified the response to the Soviet Union would be. If this point had become lost on Brezhnev he need only have been reminded of the American reaction to Khrushchev's flagrant flaunting of his "sputnik diplomacy." Alarmed by the imposed menace of a strategically superior Soviet space program, the dormant American space enterprise in an extremely short period of time was able to match and then far surpass the Soviet effort. By harnessing its vastly superior economic resources, and backed by a unified popular consensus, the United States had easily rendered useless what had been a key component of Soviet foreign policy. Brezhnev could not possibly sustain the same firm American response in the political and military field for any long period of time. Yet, Brezhnev, as he has often stated, was firmly committed to the pursuit of foreign policy objectives that would permanently tilt the balance of forces to the Soviet side at the direct expense of American interests, thus precluding a realistic peaceful rapprochement or status quo posture with the United States. However, to alarm the United States with a menacing and hostile picture of Soviet aggression would elicit a firm and tenacious American reaction, and Brezhnev's economy was no better suited for this intense competition than was Khrushchev's. It became imperative therefore, to revitalize detente, this time under the guise of the Peace Program.

The creation of the Peace Program can be seen as a manifestation of both the importance of the policy of detente, in the Soviet view, and the personal primacy of the architect of the latest variation of Soviet detente, Leonid Brezhnev. In his keynote address at the 25 th C.P.S.U. 
Congress Brezhnev asserted that:

In the field of foreign policy, the 24th Congress set forth the Peace Program. Its main purpose was, relying on the might, solidarity and activeness of world socialism and on its strengthening alliance with all progressive and peaceloving forces, to bring about a change of direction in the development of international relations. A change from the cold war to the peaceful coexistence of states with different

Throughout the course of the 25th Congress, almost all delegates, including Brezhnev, called for the further strengthening of the widely acclaimed Peace Program, established at the 24th Congress. In his report Brezhnev reported that in regard to the newly-presented proposals of the 25th Congress:

We regard these proposals as an organic continuation and development of the Peace Program advanced by the 24th Party Congress, as a program of further struggle for peace and international cooperation and for the freedom and independence of the peoples.11

It is important to note, however, that in the documents of the 24th C.P.S.U. Congress in 1971, and in praticular Brezhnev's report at that congress, no mention is made of a Peace Program as such. To be sure, Brezhnev, in his address, made repeated references to the "Soviet Union's struggle for peace," "peaceful coexistence," the "defense of peace" and so on. In addition, the report addressed in summary form much of what would later constitute the actual Peace Program. ${ }^{12}$ Yet, it remainsa fact that no new program was actually unveiled by Brezhnev at the 1971 congress. In the years since the congress the Brezhnev report itself has been acclaimed as the actual Program of Peace. One can logically question, therefore, why such a heralded program was never presented in the form of a document at the congress, was not referred to as such during the congress proceedings, and was retroactively accorded a place of paramount importance 
in the days following the congress.

It can be argued that Brezhnev's keynote address at the 24 th Congress represented a personal gamble for the General Secretary. The keynote address at a Party Congress is generalily not delivered in the form of a surprise presentation by one man, but rather is almost always scrutinized in close detail and approved by the Politburo of the C.P.S.U. well in advance of its delivery. (The report by Brezhnev, as is customary, was officially entitled "The Report of the C.P.S.U. Central Committee to the 24 th Congress of the Communist Party of the Soviet Union.") Thus, it can be reasoned that the Politburo did not fully endorse any major program, at least in the form of an official party document. (If indeed, Brezhnev attempted to present his speech in the form of an officially sanctioned program.) Nonetheless, Brezhnev took the initiative at the congress and was apparently prepared, and allowed, to either damage or improve his party position and personal career with the delivery of his report and his pursuit of the policy of detente after the congress. The historical evidence would indicate that Brezhnev succeeded very well in this regard as the Peace Program was hailed, and Brezhnev ascended to an unmatched level of party supremacy in the years between the 24th and 25th Party Congresses.

It is quite normal that a good deal of attention be paid to analyzing and discussing the resolutions of the C.P.S.U. Congresses. Surely, the 24 th C.P.S.U. Congress was no exception as widespread notoriety was given to the decisions of the congress in the Soviet media. Yet, nowhere in the mass of early post-congress discussion was mention made of a definitive peace program adopted by the 24th Party Congress. However, Brezhnev, in a flurry of post-congress activities, used many occasions 
to carefully refer to a program that was developed at the congress.

Thus, in his May Day speech of 1971, four weeks after delivering his

report to the 24th Party Congress, Brezhnev claimed:

True to the behests of the great Lenin, the 24th Congress of our party advanced a clear and constructive program of peace-loving foreign policy, which has met with warm support from the fraternal socialist countries and approval from broad masses of people the world over. The struggle for its implementation is the correct path toward the further consolidation of international security and the strengthening of the friendship of peoples. 13

Two weeks later, Brezhnev took the occasion of the Ceremonial

Session of the Georgian Communist Party Central Committee and the Georgian Republic Supreme Soviet to assert:

Developing the Leninist traditions of Soviet foreign policy, the 24 th Congress put forth a comprehensive program of struggle for peace and international cooperation, for the freedom and independence of peoples. This is a program for struggle for the triumph of the principles of peaceful coexistence, a program of the friendship of peoples and their free and independent development, this is a program of curbing the aggressors and preventing a world war. 14

Therefore, Brezhnev had established the fact, at least in his own mind, that his report at the 24th Party Congress constituted a program, and that this program was unmistakingly linked with the policy of peacefut coexistence. Shortly thereafter Brezhnev reaffirmed the existence of a party program in his speech at the Eighth Congress of the Socialist Unity Party of Germany:

A comprehensive program of struggle for peace and international security, for the freedom and independence of the peoples was put forward at the 24th Congress of the C.P.S.U. It determines the main tasks and directions of the Soviet Union's foreign policy activities at the present stage. 15

It now remained for Brezhnev to finalize the establishment of his program and to ensure its widespread acceptance. Brezhnev utilized the occasion of a "friendly meeting" of the heads of a number of communist 
parties who were on "vacation" in the Soviet Union to reinforce the primacy of his peace program. (This is the first official reference to a peace program as such that this writer has found in Soviet source material.) The meeting, which was held in the Crimea on August 2, 1971, was attended by Brezhnev, Podgorny and Shelest on the Soviet side and Zhikov (Bulgaria), Kadar (Hungary), Honecker (G.D.R.), Tsedenbal (Mongolia), Gierek (Poland), and Husak (Czechoslovakia). It was reported that the meeting "touched upon urgent questions of the development of the world Communist movement, as well as foreign policy problems of mutual interest." Most importantly, the meeting touched upon the Brezhnev peace program. As reported in the Soviet press:

The meeting participants emphasized the great importance of the peace program advanced by the 24th C.P.S.U. Congress and supported by the fraternal Communist and Worker's Parties. The implementation of this program is called upon to play a very important role in the genuine easing of international tension and in ensuring peace and the security of the peoples. 16

In the course of the next five years Brezhnev was able to expand the acceptance of the new program to the point that it was hailed as a momentous contribution to the cause of peace, the cornerstone of all Soviet foreign policy, and the most critical aspect of contemporary international life. Thus, Brezhnev could look back upon his report at the 24th Party Congress and claim:

Invariably basing its actions on this (Leninist) platform, our Party, following Lenin's behests and proceeding from the half-century experience of its peace-loving foreign policy, came out with the Peace Program at its 24th Congress. This program laid down a realistic path to the elimination of the cold war and set clear-cut tasks in the struggle for a transition from the danger of war to peaceful cooperation. 17

It can be argued therefore, that Brezhnev, through the presentation and implemention of the Peace Program, achieved an impressive personal victory. In July, 1973 Brezhnev was awarded the International Lenin Peace 
Prize, one of many awards bestowed on the General Secretary after the 24th C.P.S.U. Congress. In his acceptance speech Brezhnev demonstrated his belief that his Peace Program was a success. In Brezhnev's words:

In fulfillment of the behests of the great Lenin the 24 th Congress of our Party put forward a realistic and, as developments have shown, fruitful Peace Program.... That is why our Peace Program enjoys great esteem and recognition among workers and peasants, among al1 who are engaged in peaceful work, and is winning their growing and increasingly more effective support....

In accepting the Lenin Peace Prize I would like to assure our Party, the Soviet people, and people of good will everywhere that I will continue to do everything in my power to achieve the most wonderful and most humane objective - the objective implicit in the very name of the award conferred upon me, namely, that of strengthening peace among nations. 18

It will be argued that through the implementation of the Peace Program, Brezhnev sought to both reduce the tenacity of American reactions to Soviet policies and, more important7y, afford the U.S.S.R. a larger risk-taking potential in the pursuit of foreign policy objectives. Khrushchev's style of detente, although eliminating the need for a direct confrontation between the two superpowers, still presented a visible threat, and the American government had no difficulty in responding to this threat and generally enjoyed widespread support for taking a hard line with the Soviet Union. By extending the hand of friendship and entangling the United States in a web of bi-lateral accords however, Brezhnev had made the process of firmly responding to Soviet actions a more difficult one. Consequently, it would appear that Brezhnev had given himself a measure of control over American-Soviet relations to the degree that he could pursue foreign policy objectives, specifically in the world of developing nations, without necessarily inviting a hard line anti-Soviet position in Washington. Thus, Brezhnev can claim, as he did in a speech at the White House, that the U.S.-Soviet summits: 
...encourage us to make new big strides during the

present meeting, to give greater stability to Soviet-

American relations and thereby increase the contribution

of our countries to the cause of peace and international
detente. 19

It can be reasoned, therefore, that the initial image of the new collective leadership as perceived in the West was incorrect. In the first place, it is questionable whether or not a collective leadership ever existed. Leonid Brezhnev as one member of the new triumvirate had already suffered two major political setbacks in his career and consequently, did not seem to possess the ability to assume sole control of the Soviet ruling hierarchy. However, as historical evidence shows, it did not take long for Brezhnev to do just that and to firmly place himself in a position of preeminent stature and importance. In fact, it can be hypothesized that Brezhnev has been accorded a level of prestige and eminence in Soviet politics that surpasses that which was achieved by any Soviet political figure save Stalin. It would appear that Kosygin, Podgorny and the rest of the Politburo have for some time been relegated to a position of secondary importance as Brezhnev has pursued his own "cult of the personality." Moreover, as indicated above, Brezhnev's stature has been most evident in the area of detente where the General Secretary has clearly stamped the policy of detente with his personal imprimatur .

Brezhnev therefore, has been able to pursue the policy of detente without the inhibiting constraints that characterize a collective leadership, oligarchy, or any form of rule short of a one man dictatorship.

There are, of course, conflicting opinions regarding the overall political well-being and party dominance of Brezhnev. ${ }^{20}$ Yet, in view of his pursuit of the Peace Program and the acclaim he has received as noted above, 
Brezhnev may be seen as a major determining factor, certainly more than any political figure of group of policy makers in the Soviet Union, in regard to the formulation and pursuit of detente with the West in general and the United States in particular.

Secondly, the image of a slow moving, bureaucratic soviet leadership may be misleading in light of some aggressive tendencies displayed in Soviet foreign policy in the last ten years. The Kremlin regime has, during that time, shown no apparent unwillingness to confront the United States in areas that are considered to be important to American global interests. Furthermore, as will be argued in detail below, the U.S.S.R. has clearly set its sights on effecting pro-Soviet and antiWestern alterations in nearly all Asian, African, Latin-American, "Third World" and non-aligned nations. Such a tendency may well be caused in part by the existence of a dominant if not overwhelming party and government leader. However, it can also be argued that the appearance of an aggressive Soviet foreign policy stance is equally determined by the existence of the long sought after parity in thermonuclear capability between the Soviet Union and the United States.

Together, these two factors may well have contributed to the creation of a detente policy by the U.S.S.R. that is not only rather dynamic and vigorous in scope but also threatening to American interests. The threat, in this writer's view, is posed in many ways not the least of which is the American uncertainty as to how to denounce a policy of peaceful coexistence and reconciliation with the U.S.S.R. both effectively and wisely. It would, it seems, be politically unfeasible for any American political figure, especially one occupying the White House, to categorically reject a policy of peace and friendly relations with the 
world's other thermonuclear superpower. Ronald Reagan, the Republican Party's presidential nominee, made fairly direct references to such a foreign policy stance during much of his campaign. Yet, it has also become apparent here, despite minority opposition within his own party, that Reagan was willing to be advised by Henry Kissinger, the chief engineer of the latest U.S. version of detente with the U.S.S.R.

President Carter pursued what appeared to be a hard line in dealing with the Soviet Union, but only after a flagrant military intervention by the U.S.S.R. in Afghanistan. Even here, the American president was compelled to utilize such unheralded foreign policy responses as the boycott of the Moscow-hosted 01ympic Games and a partial grain embargo to register the American opposition to Soviet actions.

The result, and a basic hypothesis of this dissertation, is that the Soviet Union, and Brezhnev in particular, enjoys a fairly enviable position at the present time in regard to relations with the West. The policy of detente is very aggressive, especially in terms of the pursuit of Soviet objectives in the "developing nations" of the world, or in the Soviet vernacular, the nations "seeking national liberation." Yet, the Soviet presentation of detente is quite appealing to most, in that it offers no overt manifestations of hostility or direct confrontation. Hence, it can be argued that detente becomes quite attractive politically to those who are weary of a cold war posture between the East and West. Thus, it is not surprising that many West European political leaders, most notably in France and the Federal Republic of Germany, have found it difficult to wholeheartedly endorse any American denunciation of the Soviet Union. Detente, in the view of most observers, is popular among the West European masses, and popular support can easily translate into 
election votes as witnessed by Helmut Schmidt's victory in October, 1980. What Brezhnev has been able to achieve therefore, is impressive. Brezhnev has succeeded in maintaining the aggressive tendencies of detente as practiced by Khrushchev while at the same time making the policy attractive, or at least "un-rejectable" to the West.

Thus, Brezhnev can outline the aggressive scope of detente as follows:

... Our common duty is to move tirelessly forward along the chosen path, to move steadily, perseveringly, along a a wide front, resolutely breaking down the resistance of the adversaries of detente, and the proponents of "cold war." As we in the Soviet Union see it, the task is to make the detente achieved in the decisive areas of international re lations stable, durable, and, what is more, irreversible. 21

In addition, Brezhnev can issue a warning in regard to those who might see a passive Soviet foreign policy in light of the U.S.-Soviet detente. As stated by Brezhnev:

Let me remind you that Lenin, that greatest of revolutionaries, used to say: Revolutions are not made to order or by compact. And we might add that neither can revolution, class struggle, nor the liberation movements be abolished to order or by agreement. No power on earth is capable of reversing the inexorable process of the resurgence of social life. Wherever there is colonialism, there is bound to be struggle for national liberation. Wherever there is exploitation, there is bound to be struggle for the emancipation of labor. Whereever there is aggression, there is bound to be resistance.22

In short, an argument can be made that the style of detente as practiced by Leonid Brezhnev has been a far more successful enterprise than that which was implemented by any of his predecessors. The Soviet Union under Brezhnev enjoys the military, political, and economic stability that was never realized by Lenin. Hence, detente lacks the oftentimes desperate and "necessary evil" characteristics that marked detente during Lenin's lifetime. In much the same way Brezhnev has found himself in a much more enviable posture than that which was achieved by Stalin, who also found detente to be an unpleasant yet quite necessary policy. 
Thus, Brezhnev has been able, with a good deal of success, to transform Stalin's defensive and hostile detente into an offensive but apparently non-threatening device. The achievement of thermonuclear strategic parity with the West has also provided Brezhnev with the final factor that rendered the Khrushchev formula of detente incomplete. However, Brezhnev has proven to be a better practitioner of detente than was Khrushchev and has balanced aggressiveness with outward signs of reconciliation and friendiness.

Brezhnev has therefore, given the detente policy a thorough overhaul and clearly differentiated his detente from any that was practiced by preceding Soviet rulers. Yet, the Soviets claim that detente today is a continuation of the detente initiated by Lenin. This is true to a degree; the ideological and historical continuity of the Soviet policy of detente is quite strong from 1918 to 1980. In Brezhnev's view, the continuity from Lenin to the present is obvious. In the words of Brezhnev:

The founder of our Soviet state, Valdimir Ilyich Lenin, put forward and made a persuasive case for the principle of peaceful coexistence of states belonging to different social and political systems - this was many decades before the word detente acquired its present meaning. The principle demand is that states not interfere in each others internal affairs and they not use force to decide disputed issues, and that normal peaceful and businesslike relations be maintained between socialist and capitalist countries. 23

Aga in, as stated by Brezhnev:

...The very notion of peaceful coexistence, which is these days increasingly becoming the generally recognized foundation for developing relations between states with differing social systems, was formulated by the founder of the Soviet state, Vladimir Ilyich Lenin.24

It is necessary therefore, to examine the eight detente variables that Lenin established in 1918 in comparison to those employed by Brezhnev in his revitalization of detente. 
Detente as a breathing spe 11. It was shown above that one dominant characteristic of detente as employed by Lenin was detente as a breathing spe11, a respite in war whereby the Soviet Union could concentrate all its energy and resources on the tasks of guaranteeing its basic survival. Lenin's detente was a desperate one and was compelled by the utmost necessity of diverting any major military thrust against the Soviet Union so that Lenin could establish the conditions for consolidating the economic, political, and military strength of his new regime. Above all, detente would establish the necessary preconditions, for first ensuring the continued existence of the Soviet state and then for the construction of socialism within the U.S.S.R.

Brezhnev was obviously not confronted with the level of desperation that was faced by Lenin, as the very survival of the Soviet Union was not threatened. Yet, Brezhnev was equally in need of a respite from war and for a peaceful posture with the West. For Brezhnev this peace would establish the preconditions not for survival or internal socialist construction but rather for the worldwide proliferation of socialism and of communist construction. The Soviet Union has made no attempt to conceal the fact that detente provides an advantageous position for the pursuit of these objectives. In the words of Brezhnev:

... I would like to assure you that we shall continue consistently and steadfastiy to implement the principled class course defined by the Party Program and the decisions of the Party Congresses, a foreign policy line aimed at the defense and strengthening of peace and at the creation of the best international conditions for the construction of a communist society. We see this as our revolutionary duty to the Soviet people and to the working people of all countries.25

In Brezhnev's view, the pursuit of the Peace Program offered the U.S.S.R. new opportunities in the international arena. In Brezhnev's words: 
...An appraisal of the general alignment of forces in the world led us several years ago to this conclusion, namely, that a real opportunity existed for bringing about a fundamental change in the international situation. The important thing was to furnish a broad basis for constructive discussion and solution of the problems that had accumulated. These considerations and our policy were summed up in the Peace Program proclaimed by the 24 th Congress of the C.P.S.U.26

Brezhnev can also claim that the Party's foreign policy is designed to protect the Soviet Union against war and "opens vast vistas for promoting friendship and co-operation between nations and advances the cause of social progress on our planet."27 A similar view is expressed by Mikhail Suslov, a member of the C.P.S.U. Politburo and the acknowledged party theoretician and ideology expert. In the words of Sus lov:

At the same time, a certain easing of international tension, the retreat of the policy of war and aggression and the failure of the "cold war" are opening up to the world's progressive forces additional possibilities for developing the struggle of the working people against the oppression of the capitalist monopolies and for their own rights and interests and for upholding and strengthening democratic freedoms.28

In analyzing the changes in U.S.-Soviet relations inherent in the new detente Georgi Arbatov depicts the new relationship in the terms of Soviet foreign policy. This foreign policy, according to Arbatov, "has always been determined by a sincere desire to put an end to war and aggression, to ensure peace and security for the peoples, and to create for the Soviet people and the peoples of the other socialist countries the most favorable conditions for the construction of a new society." 29 Detente has been criticized by many Western observers as accruing unilateral advantages to the Soviet cause. In the face of such criticism Brezhnev resolutely maintains that detente is, in fact, a policy geared to the "supreme good for al1 peoples and an important condition for the progress of mankind in our time." 30 In his keynote address at the 25 th 
C.P.S.U. Congress, Brezhnev elaborated further:

We make no secret of the fact that we see detente as a path leading to the creation of more favorable conditions for peaceful socialist and communist construction. This only confirms that socialism and peace are indivisible. When we are reproached for saying this, it is hard to keep from thinking that those who reproach us lack confidence that capitalism is capable of existing without resorting to aggression and threats of arms, without encroaching on the independence and interests of other peoples.31

In an interview granted to French television some eight months after the congress, Brezhnev was questioned on the allegation that detente did indeed appear as a policy that was "advantageous only to the Soviet Union and other socialist countries." In his response Brezhnev first claimed that "such a viewpoint seems strange to us, to say the least," then continued:

Of course, we have not concealed and do not conceal the fact that plans for the internal development of the Soviet Union are built on the expectation that peaceful external conditions will be ensured, and therefore detente is beneficial to us. But does peace really threaten something bad for other peoples? Is there really a people that can hope to win anything from unleashing a world war using today's means of mass annihilation?32

One of the major components of Brezhnev's detente formula is the fact that the growing might of the Soviet Union and the alignment of world forces in favor of socialism have made the creation of this favorable detente possible. While this "alignment of world forces" theory will be examined in detail below, it is important to draw the connection here to the view of detente as a necessary breathing spe11. In the words of Arbator detente has "become possible thanks to the growing might of the Soviet Union, and the entire socialist commonwealth, thanks to the vigorous actions of the international working class and the national liberation movement and the strengthening of the forces of peace and progress the world over." ${ }^{33}$ Arguing this position, Arbatov can conclude 
that the West was forced to enter into a detente relationship with the Soviet Union in the face of the growing might of world socialism. The Soviets, in this view, had aiways pursued the objectives of world peace and relaxation of tensions; yet as Arbatov claims:

However the goodwill of the Soviet Union and the other socialist states has not been enough for the realization of these goals. It was also necessary to have definite objective preconditions, and these preconditions have appeared in our days... - the willingness and agreement of the other side, the capitalist world to build its relations with the world of socialism on the foundation of the principles of peacefur
coexistence. 34

Brezhnev has often claimed that the correlation of world forces is an important concern. As stated by the General secretary:

We are deeply convinced that the current change-about from "cold war" to detente, from military confrontation to a more solid security and to peaceful cooperation is the main tendency in present day international relations.

How has this become possible?

The main factor, we are certain, is the general change in the correlation of world forces - a change that is against the exponents of "cold war" and the building up of arms and those who fancy diverse military ventures, a change in favor of the forces of peace and progress. 35

In much the same manner Brezhnev can argue that "thanks to the growth of the might and international influence of the Soviet Union and the entire socialist commonwealth...the cause of easing of tensions has advanced and the security of the peoples has been strengthened." 36 Moreover, Brezhnev can claim that:

As a result, international conditions for communist and socialist construction and for the struggle for the social progress of the peoples have become more favorable. This makes it possible for us to an increasing extent to concentrate on the accomplishment of peaceful, constructive tasks. Naturally, we are satisfied with this course of events. 37

Lenin had always claimed that the primary objective of the detente policy was the immediate internal consolidation of power and socialist construction within the U.S.S.R. By accomplishing this goal 
Lenin, as well as Stalin and Khrushchev later, felt that the Soviet Union could better render assistance to the worldwide socialist movement. The first task, however, was internal consolidation and construction. Much the same sentiment is echoed by Brezhnev in implementing the latest detente. While detente does provide favorable conditions for the further dissemination of socialism abroad, it also provides the needed breathing spell for the internal "construction of a new society" as outlined above. Brezhnev therefore, draws a direct link between the foreign and domestic components of detente:

Our Party, loyal to the great ideas of proletarian internationalism, has never separated the destiny of the Soviet land from the destiny of the countries of Europe and the whole world. The U.S.S.R.'s foreign policy aimed at consolidating peace and the freedom of peoples, and our domestic policy, whose goal is the building of communism, not only correspond to the fundamental interests of the Soviet people but also, we are convinced, are our contribution to the common struggle of the whole world's Communists for a better future for mankind. 38

In a similar fashion, Brezhnev can argue as follows:

Our peaceable foreign policy is an expression of the very essence of our society, an expression of its profound internal requisites.... Our aim is to ensure that tomorrow the Soviet people will live even better than today. Soviet people feel tangibly the results of these collective efforts. ${ }^{39}$

Lenin's respite was transient in nature and would come to an abrupt end when the Soviet state was capable of waging a victorious war against the West. Brezhnev's breathing spe11, under the right conditions would be nearly eternal, and would end only after the victorious construction of communism, first in the Soviet Union, then in the rest of the socialist and non-socialist world. The Soviets have long advocated that detente should be made irreversible and that the breathing spell offered by detente should be transformed into a permanent peace. While Lenin's breathing spell was a respite between wars, Brezhnev's breathing 
spell would be the catalyst for permanent communist construction without the need for any war. As Brezhnev has stated:

The best way of defending peace is to continue actively pursuing our policy of peace, to continue our - as people now call it - peace offensive.

At its Plenary Meeting in April, the Central Committee of the Communist Party of the Soviet Union instructed the Politburo to carry on its vigorous efforts to implement the Peace Program in its entirety and to make irreversible the favorable changes that are now being increasingly felt in the international situation. 40

In analyzing the Leninist detente format, Soviet commentators can claim that "it took the genius and unbending will of Lenin and the wisdom and political maturity of the Party that he reared to work out and then to consistently implement the only correct policy - a policy of peaceful coexistence... of two systems of ownership, two opposing economic and socio-political systems." 41 Yet, in the words of Politburo member Yuri Andropov, this policy was a temporary one aimed at providing the much needed breathing spe11:

Of course, at that time there could be no talk of excluding war from the people's lives. As a great realist, Lenin realized that the imperialist powers would not leave revolutionary Russia alone, that the peace won in a painful struggle would only be a "postponement of war," only a breathing space of peace.

And our country received this breathing space. We gained two decades. This helped us to be victorious in a war that was the most terrible, the most bloody of all wars mankind has gone through... 42

The Soviet Union does not attempt to conceal the fact that detente has provided and continues to provide the breathing spell that is quite necessary for internal consolidation and/or socialist or communist construction. However, the theory of detente as a breathing spell for Lenin must be added to the theory of the present alignment of forces in favor of socialism, to show the permanent nature of the present respite. By continuing the reasoning of the Leninist breathing spe11, it can be argued 
that "today this question - which is certainly not a new one - is being posed and resolved in a different way." 43 This different way, of course, is dictated by the "alignment of world forces" in favor of socialism, which "creates the prerequisites for...the total elimination of the danger of a new world war... and expands the limits of peaceful coexistence." 44 Andropov can conclude the argument then by asserting that: "The Party now sets itself the goal not of winning a breathing space of peace but of establishing a lasting and just peace on earth." 45

Soviet spokesmen from Lenin to Brezhnev have always argued that the prerequisite for internal consolidation and the building of a socialist/communist society is the absence of war. Lenin told us that it would be foolish to embark upon the goals of domestic construction in the face of anything but peaceful relations with the capitalist-imperialist world. Peace, in Lenin's mind created the most favorable, indeed the only, condition for the creation of his new society. Likewise, Soviet commentators in the era of the new detente realize the same truism:

It is a class policy (the policy of detente) because above all else it is based on the vital interests of socialism and the interests of socialist and communist construction. The new society needs peace - it is easier for the new society 46 to build in conditions of detente and a diminished arms burden.

It is also easier for the "new society" to build in an era when vast amounts of financial resources from a limited and relatively weak economy are not allocated to a burgeoning arms race. As mentioned above, the Soviet Union has appropriated an inordinate percentage of its national economy to its military/defense budget. With a Gross National Product far inferior to that of the United States, the U.S.S.R. still matches its chief rival in military expenditures. Accordingly, it can be argued that the "new society" must be built with the relatively low 
budget that remains after the military appropriation has been made. As outlined above, Brezhnev cannot sustain this intense ruble-for-dollar military spending and still hope to achieve any measure of success in addressing major domestic concerns. The breathing spell therefore, would afford Brezhnev the opportunity to divert funds to just such domestic enterprises. In speaking of the arms race, and specifically the unanswered questions of arms limitation, Brezhnev asserted that:

However they remain on the agenda. There is really no need to say how beneficial their implementation would be for the strengthening of mutual confidence. Moreover, both sides would receive an opportunity to save substantial sums of money and to use this money for productive purposes, for improving people's lives. 47

It is reasonable to surmise that Brezhnev has had to temper his policy of detente with assurances that military vigilance and military expenditures would not be drastically reduced. Hence, he has repeatedly claimed that the Soviet Union will "continue to maintain the country's Armed Forces at a high level, so that Soviet fighting men will always have the most up-to-date weapons, arms that the imperialists must take into account - this is our duty to the people, and we will fulfill this sacred duty." 48 Yet, Brezhnev again is mindful of the need to secure a breathing spell so as to re-channel much of this military spending into other areas of the Soviet economy. Therefore, after promising military and defense vigilance at the highest level, Brezhnev can argue as follows:

At the same time, we have no greater desire than to transfer the resources that are now of necessity diverted from the national economy into raising the working people's living standard, into constructive purposes. We are prepared tomorrow to start disarmament measures - either major, radical measures or, as a start, partial ones - on a genuinely fair reciprocal basis. 49

It can be argued that a constant state of intense competition with the United States, be it in the military, economic, or foreign policy 
realm, has never suited the needs of the Soviet Union. Such a state has always placed the U.S.S.R. in a disadvantageous position vis-a-vis its more economically powerful adversary. Hence, a breathing spell has often been quite necessary for the Kremlin regime from the earliest days of Soviet power. Lenin, of course, needed this breathing spell to survive. Brezhnev, assured of his nation's survival, needs this respite to focus energies on some rather ambitious domestic objectives. However, Brezhnev, unlike Lenin, is in a fairly good position to make his breathing spell a permanent fixture of Soviet foreign policy and an irreversible component of East-West relations.

The Soviet Union as a socialist oasis. One of the major determining factors motivating Lenin to embark upon detente in 1918 was the fact that Soviet Russia was, as he depicted it, "an oasis in a raging sea of imperialism." Hopelessly outnumbered by his more formidable capitalistimperialist enemies, and thwarted by the abortive socialist upheaval in Germany, Lenin reasoned that he had no choice but to reach an accommodation of sorts with the West. This may have been the most evil of necessities for Lenin, yet until the balance of power could be shifted or allies found, he had no choice but to coexist with his hated enemies.

Brezhnev has not been confronted with such a desperate position. Far removed from the position of an oasis, the Soviet Union has for some time stood at the head of an ever-increasing commonwealth of socialist states. Soviet influence may have been forced upon many countries, allies may have been created and not earned, and the communist world may have become fragmented. Yet, there is no denying that the communist world's size and strength is impressive and that the Soviet Union is in a position of international strength beyond that which Lenin had achieved. 
This fact has radically altered this particular component of detente from Lenin to Brezhnev. Lenin found detente to be a necessity because of the weakness of Soviet Russia and the non-existence of a socialist camp of allies. Brezhnev, on the other hand, has found detente to be a policy that would be forced upon the West with the realization there of the growing might of the Soviet Union and the new alignment of world forces in favor of the socialist camp. What Lenin could not achieve was used by Brezhnev as a springboard to launch his new aggressive detente. Brezhnev, in analyzing the present alignment of world forces, has claimed:

Our optimism is based on the successes already achieved by the policy of peaceful coexistence, on the fact that the ruling circles in some of the capitalist countries are showing a growing appreciation of the real correlation of world forces and are coming to realize that war is unacceptable as a means for solving international problems.50

This point has been reinforced by Brezhnev a number of times. Again, in Brezhnev's words:

The relaxation of international tensions has become possible because a new correlation of forces now exists on the world scene. Today the leaders of the bourgeois world can no longer seriously expect to decide the historical dispute between capitalism and socialism by force of arms.51

Much the same sentiment has been voiced by Suslov:

As a result of the vigorous foreign policy of the Soviet Union...the Leninist principle of peaceful coexistence is being affirmed more and more in international affairs... Having run into a resolute rebuff from the united forces of world socialism, the workers' and national liberation movement and all fighters for peace, international imperialism has been compelled to retreat, and its representatives are sitting down at the negotiating table...52

The Soviet Union on a number of occasions, has reiterated this basic foundation of detente in the 1970's. Detente, in the Soviet view, was not a mutually agreed to rapprochement between the two conflicting 
socioeconomic systems. Nor was detente the result of an American willingness to peacefully coexist with the Soviet Union. Detente, according to Brezhnev, was always practiced by the Kremlin rulers, and was always thwarted by the United States. The United States agreed to formalize detente with the U.S.S.R. because it had no choice but to do so. Faced with the awesome military might of the Soviet Union, and confronted with the alignment of world forces in favor of socialism, the United States finally realized the hopelessness of pursuing an anti-Soviet and anti-communist foreign policy. The United States did not agree to a detente with the Soviet Union; detente was forced upon the United States by its realization of the objective factors underlying the balance of power in the world. Suslov again underscores this point, in relation to the increased ideological struggle:

... With the changes in the world situation that favor socialism, the hopelessness of any attempts to bring military, economic, or political pressure to bear on the Soviet Union or the socialist commonwealth as a whole becomes more and more obvious. This being the case, the struggle becomes particularly acute in the area of ideology, an area in which there is not and cannot be peaceful coexistence between socialism and capitalism. 53

In his keynote address at the 25th C.P.S.U. Congress, Brezhnev boastfully claimed that "the world is changing before our eyes, and it is changing for the better. Our people and our Party are not passive onlookers of these changes. No, we are active participants in them. "54 What Brezhnev saw changing before his eyes was the growth of socialist influence abroad and the consolidation of strength by the socialist commonwealth. Brezhnev could point to victories in Vietnam, national liberation victories among the developing nations, communist party gains in Western Europe, socialist construction in Cuba and a host of other real or imagined triumphs. 55 The relations with the capitalist states cuuld 
then be summarized by Brezhnev as follows:

The main element in our policy with respect to the capitalist states has been and remains the struggle for the affirmation of the principles of peaceful coexistence, for lasting peace, and for lessening and in the long run eliminating the danger that a new world war will break out...

The transition from the cold war and the explosive confrontation of two worlds to the easing of tension was connected above a 11 with changes in the alignment of forces in the world

This alignment of forces in the world arena, and specifically the alignment in favor of the socialist camp, provides the main characteristic of international relations from the Soviet perspective. Georgi Arbatov, in analyzing Soviet-American relations reasons that:

As a matter of fact this constitutes one of the principal features of the present world situation. Recent international events, including events bearing on the relations between the U.S.S.R. and the U.S.A., provide practical confirmation for these conclusions and show that the change in the alignment of forces is not some abstract formula but a tangible reaity that makes it possible to bring about major positive changes in the international situation. The important shift in the alignment of forces in the world arena and the favorable new opportunities that this opens up have been created to a significant extent by the Soviet Union itself...57

The Soviet view of the present international environment is based on an analysis of what the Soviets feel are unquestionable objective factors. The most obvious of these objective criteria, and one that has finally been realized by the United States, is the aforementioned theory of the alignment of world forces. Soviet commentators can assert therefore, that the improvement in U.S.-Soviet relations was conditioned by a number of factors, and that:

Among these factors, a special place is held by the alignment of forces in the world arena, which is steadily changing in favor of socialism. In the final analysis, it was this factor that made the capitalist world, after prolonged and fierce resistance, recognize the changes that have been wrought as a result of socialist revolutions on a substantial part of the globe - and this is an important 
aspect of what is now taking place in Europe and in a number of other parts of the world. 58

Brezhnev is especialiy fond of asserting the alignment of worid forces dictum in regard to the situation in Europe where the heart of the Soviet bloc is still to be found and where communist parties have made some impressive inroads. Brezhnev has often claimed that contemporary Europe is far different from the continent that was embroiled in World War II. This, according to Brezhnev is a positive change that was brought about by the fact that "the alignment of class forces has changed, both on the international level and within many states. The role that the working class and its vanguard, the Communist Parties, play in European public life has grown tremendously..." 59 This alignment then yields tremendous benefits, in Brezhnev's view, for the European continent:

The Europe of today is to a large extent the fruit of the successful construction of socialism and communism in a number of the continent's countries. It is also the fruit of the persistent and steadfast struggle for peace the socialist countries are waging in the international arena...

Today it is clearer than ever that imperialism can no longer dictate the destiny of Europe. The socialist states and the workers' and democratic movement in the capitalist countries now have an important say in deciding this destiny. 60

The all-European security conference held in Helsinki was of great importance to the Soviet Union in that it confirmed many of the Soviet claims that the re-alignment of world forces in favor of socialism was a reality on the European continent. Brezhnev has stated, in light of the Helsinki accords, that the proper preconditions for solidifying detente have been created in Europe:

The most important results of the liberation struggle of the European peoples during World War II and thereafter have been consolidated. Preconditions have been created for lasting peace and good-neighbor cooperation both in Europe and outside it. 6 
The Helsinki accords, in Brezhnev's view, have legalized and accorded widespread recognition of the post-World War II socialist gains in Europe. Thus, Brezhnev can claim:

The positions of socialism and the influence of the concerted policy of the socialist states are strongest in Europe. The 24th Congress posed the task of ensuring European security on the basis of recognition of the territorial and political realities that came about as a result of World War II. It is along these lines that our Central Committee has acted.62

The convocation of an all-European conference on security had been an objective of the Soviet Union for some time. ${ }^{63}$ To convene and successfully complete such a conference would, in the Soviet view, provide the means by which the process of detente could best be served in Europe. In effect, the Helsinki accords provided the means by which many of the Soviet objectives inherent in detente could best be realized. In the first place, it seems evident that the U.S.S.R. would hope to realize a reduction in the U.S. military presence in Europe; a reduction that might be prompted by a reduced image of the Soviet menace. As Brezhnev has claimed:

Common sense notwithstanding, "responsibility" is ascribed to the socialist countries for internal political events in other states and for civil wars and wars of national liberation. The man in the street is intimidated by the idea of "hordes of Russian tanks" and is told that the U.S.S.R. and the other Warsaw Treaty countries are building up armaments on a vast scale and.preparing for "war against Western Europe."

But these fabrications collapse like a house of cards as soon as we look at facts, at reality. 64

Secondly, it would appear that the Soviet Union hoped to use detente, as expressed in the Helsinki documents, as a means for reducing European dependancy on American economic assistance. This, it would seem, could best be accomplished by expanding the levels of intra-European and Soviet-European trade and economic contacts. In the words of Brezhnev, when analyzing the Helsinki accords: 
It is also extremely important to create, so to speak, the material fabric of peaceful cooperation in Europe, a fabric that would strengthen ties among European peoples and states and would give them an increasing stake in the preservation of peace for many years to come. I have in mind various forms of mutually advantageous cooperation - trade and production cooperation and scientific-technical ties. 65

It $c$ an be argued that the Soviet Union hoped to gain a major psychological victory through the Helsinki accords and to demonstrate that detente had indeed become an irreversible process on the European continent. One of the features of this strategy, again, was to portray the U.S.S.R. in terms of a cooperative and non-threatening neighbor. As stated by Brezhnev:

The main thing now is to implement in practice all the principles and understandings agreed upon in Helsinki. The Soviet Union is acting and will continue to act in precisely this way. Recently we offered certain proposals on the development of all-European cooperation in a number of important fields. We shall continue to make efforts in this direction. We expect the same approach from all other participants in the al7-European conference.

Thus, there have been achievements in the establishment of peaceful relations in Europe, and, comrades, these are considerable achievements. 66

The Helsinki conference would lay the formal groundwork for the consolidation and official recognition of the favorable realignment of forces that had already taken place in Europe and provide the means by which the offensive strategy of detente could further this favorable realignment in the future. It seemed important to the Soviet Union that the final recognition of the widely accepted facts of post-World War II socialist gains in Europe be granted by the West. It appeared to be imperative that the U.S.S.R. solidify the detente process with the nations of Western Europe so as to ensure the attainment of Soviet objectives in the future. These two concerns, as expressed by Brezhnev, were both addressed by the signing of the Final Act of the Helsinki conference: 
The results achieved are worth the efforts expended. The conference participants collectively reaffirmed the inviolability of existing borders. A set of principles for relations between states was worked out, principles that fully - in both letter and spirit - correspond to the requirements of peacefuT coexistence. Thus, favorable conditions have been created for the preservation and consolidation of peace throughout the con-
tinent.

In large part the conference's results are aimed at the future. 67

It has been claimed that the Soviet victory at Helsinki was not a major one in that the Soviet hegemony in Eastern Europe was no.more legitimate after August, 1975 than it was before. ${ }^{68}$ The Soviet Union, for the reasons outlined above, holds a vastly different view. In the words of Brezhnev:

The principles of peaceful coexistence have become the leading trend in relations among states. The most complete reflection of this was the successful holding of the a17European conference, in which the U.S. and Canada participated.69

However, it is specifically in regard to the United States that the Soviet Union has most adamantly asserted the theory of the alignment of world forces. For, as Brezhnev has claimed; "speaking of our relations with the United States, we regard their improvement as an organic component in the overall progress of fundamental changes in the international climate on our planet." 70 The United States not only represents the most formidable opponent that the Soviets must face, it also embodies what the U.S.S.R. has claimed is the essence of hostile anti-Soviet activity. To transform U.S.-Soviet relations, and more importantly to force the United States to recognize the objective international factors confronting it, represents a triumph in the Soviet view. It was in the United States that the U.S.S.R. was confronted with the "most primitive forms of bellicose anticommunism," with charges of the "red menace," and with the policy of communist containment, among others. However, the 
Soviets can now claim, by reasoning from their analysis of the new

"objective" international factors, that:

In the new conditions, the complete bankruptcy of the former view of the world, a view dictated by rabid anticommunism, a view according to which the main and most important goal of the U.S. foreign policy was to inflict the greatest possible damage on the Soviet Union and the other socialist countries, became apparent.71

As will be shown below the U.S.S.R. steadfastly adheres to the belief that the realization of these factors does not in any way diminish the ideological struggle between the United States and the Soviet Union. On the contrary, the new detente presupposes an increased ideological warfare with the United States which now must resign itself to a position of coexistence with the U.S.S.R. Thus, Suslov can claim that:

The fact that anticommunism faces inevitable doom in no way signifies that it will lay down arms of its own free will, however. Our class enemies are trying to compensate for the inner shakiness of their ideological positions by intensified development of the mass media and employment of the most sophisticated methods of ideological sabotage.

They are building up the capability of the press, radio and television, and they are evidencing a clear intent to make their progaganda global in character. 72

In regard to the new alignment of forces, the Soviet Union claims that: "Neediess to say, this does not mean that the American monopolies revised their attitude toward socialism and communist ideas. No, nothing changed in this respect. ${ }^{73}$ Yet, as Arbatov is quick to point out:

But the world in which the imperialist powers have to live and act has changed. It is to these changes, to the objective reality of the present situation, that they have to adapt their domestic and foreign policy.74

The stark realization by the United States of the objective correlation of world forces and increased might of the Soviet Union is not, in the Soviet view, limited to any one political party or 
presidential administration. Richard Nixon may have been the first to recognize these objective factors. Yet, Gerald Ford, and any succeeding chief executive, would be equally compelled to pursue the only rational course of action with the U.S.S.R.; the detente course. The Ford-Carter presidential campaign was quite closely observed by the Soviet Union in regard to the question of detente. Brezhnev, in analyzing the campaign, was concerned with the hard line posture with the Soviet Union and the calls for increased defense appropriations. However, in summary the C.P.S.U.'s General Secretary was led to conclude:

Nevertheless, no matter who is in power in Washington after the election, the United States apparently will have to reckon with the actual alignment of forces in the world, which in recent years has impelled American ruling circles, after soberly appraising the situation, to begin a search for accords with the socialist world...75

By way of summary, it can be argued that the Leninist position as a socialist "oasis" in a capitalist world does not pertain to the situation during the period of rule by Brezhnev. In fact, the Soviet Union today could argue that the present international environment, replete with the favorable alignment of forces in the world arena, is the antithesis of the international situation as it existed during Lenin's lifetime. Detente in 1918 was forced upon Lenin by his recognition of the objective reality confronting him. Detente in 1980 is being forced upon the United States by its recognition of the same objective factors; the international balance of power that has shifted heavily to the camp of the enemy.

Detente as a reaction to American military superiority. A serious constraint placed upon Lenin in his quest to expand Soviet influence abroad was the inordinate military superiority that was enjoyed by the capitalist-imperialist camp. In fact, the elimination of the military 
imbalance favoring the West became the main objective of Lenin's longterm detente strategy. Arguing from his theory of war and its inevitability, Lenin reasoned that military equality, and eventual superiority by the Soviet Union, was of utmost necessity if he were to realize any success in foreign policy. War would be the handmaiden for the exportation of Lenin's revolution, yet war could not be waged until the Soviet Union was assured of military victory.

This particular component of Lenin's detente has changed considerably. In the first place, the Soviet Union since 1956 has advocated the theory that wars, especially in the form of life and death struggles between the two opposing sociopolitical systems, are not inevitable. There is, to be sure, a persistent danger of war, especially in the form of a reckless anti-Soviet thrust by the hopelessly frustrated capitalistimperialist states. Brezhnev has often elaborated on the persistent threat of war. In Brezhnev's words:

Imperialism's forces of aggression will evidently not lay down their arms for a long time. There are still adventurers who are capable of kindling another military conflagration in order to further their own mercenary interests. We therefore consider that it is our sacred duty to conduct our policy in such a way as to avoid being caught unawares by any emergency and firmly to counter any attempt at returning the world to "cold war" days. 76

Yet, Lenin's view of the inevitability of such wars is not shared by Brezhnev. Thus, in addressing an American audience, Brezhnev can assert:

There is bound to be an ideological debate between us as to whose world view is more correct and whose way of life is better. Here there is bound to be competition between the two systems. But let us agree that the historical dispute cannot be decided on the battlefield of nuclear war. History will in due course deliver its verdict. 77 
Secondly, and most importantly, the Soviet Union has made impressive gains in this area, and is no longer a vastly unequal adversary of the United States. In fact, the U.S.S.R. by most accepted standards has now achieved a relative military parity with the United States. It is this military equality between the United States and the Soviet Union that clearly separates Brezhnev's detente from any of its previous forms and, it can be argued, which makes detente under Brezhnev a more aggressive and threatening component of Soviet foreign policy. Brezhnev has alluded to the existence of strategic parity in the following manner:

Our efforts are directed precisely at averting the first strike and the second strike, indeed at averting nuclear war in general. Our approach on these questions can be formulated as follows: the defense potential of the Soviet Union must be at a level that would deter anyone from attempting to disrupt our peaceful life.78

The history of Soviet-American detente until quite recently has been set amidst the background of a vastly superior military arsenal of the United States. Lenin, of course, languished in this setting of American military might throughout his tenure in power. Stalin, as historical evidence shows, made significant gains in altering the U.S.-Soviet military equation; yet Stalin never achieved a realistic parity between the two countries. Khrushchev, for his part, made repeated attempts to offset the strategic inferiority of the Soviet Union. However, Khrushchev, as did his predecessors, met with little success and was compelled to conduct Soviet foreign policy in an environment marked by American hegemony in the field of strategic weapons. It can be reasoned that it was the lack of military parity or Soviet military superiority that stood as the missing link in Khrushchev's policy of using detente as an offensive global strategy. 
has added it to the formula of Soviet-American detente. It is quite important to emphasize this point. The achievement of strategic parity with the United States has given Brezhnev the opportunity to greatly increase the risk-taking potential in Soviet foreign policy; and Brezhnev has apparently not allowed this opportunity to bypass him. While pursuing an aggressive foreign policy line, Brezhnev is able to temper any American response with a new form of sabre rattling. Brezhnev has shown no reticence to continualiy remind the United States of the grave issues involving "weapons of mass annihilation," the "global destructive power of nuclear weapons," and the like. In so doing, Brezhnev is reinforcing the stated American goal of detente; to do everything necessary to avoid a thermonuclear confrontation with the Soviet Union. As was seen above, the United States has shown a willingness to adhere to this formula of detente and is ready to moderate its own position in some cases so as to avoid inviting a thermonuclear holocaust that would "threaten the very existence of mankind." Detente under Brezhnev may be in the guise of the "Peace Program," the hand of friendship may have been extended to the United States, and Soviet prestige and socialist gains may be achieved on an incremental basis without the need for a SovietAmerican thermonuclear exchange. Yet, it can be argued that the constant threat of such an exchange amidst the background of strategic parity provides the basis by which the constraints and limitations imposed on Soviet foreign policy have been greatly reduced.

The achievement of strategic parity and the "growing military might of the Soviet Union," are closely intertwined with the Soviet dictum of the "alignment of world forces" in favor of socialism. Together, in the Soviet view, they form the complete East-West formula 
that has forced the United States to agree to detente with the Soviet Union. In the words of the late Soviet Defense Minister Marshall A.A. Grechko, a member of the Politburo:

The successful implementation of the Peace Program is conditioned by the existing balance of world forces and continued orderly changes in this balance in favor of socialism. It was prepared by decades of selfless struggle of Soviet people... and by the U.S.S.R.'s transformation into an invincible fortress of socialism...79

Confronted with the reality of this "invincible fortress," the United States was, in the Soviet view, compelled to re-assess the role of military force in regard to relations with the Soviet Union. According to this view, "the growth of the Soviet Union's defensive might have dispelled hopes that the U.S.A. would be able to achieve military superiority, which would have enabled it to reach its goals with the help of the use of military force, or the threat of its use." 80 The American recognition of the military might and strategic capabilities of the Soviet Union forced the ruling circles in Washington to re-evaluate the efficacy of confronting the U.S.S.R. militarily. This re-assessment compelled the United States to "come to the conclusion that reliance on military victory over the socialist commonwealth was groundless and that a nuclear war would in fact prove suicidal for America itself." 87 Brezhnev can also claim that the new historical era, characterized by the growing might of the socialist world, will serve as a barrier against war. In the words of Brezhnev:

Neither the lessons of history nor what would appear to be man's natural aversion to killing his like has ever prevented new blood baths, because the forces of war, the role of those who stood to gain from war, were too great.

In our epoch this state of affairs has changed fundamentally. Today, the struggle against war has a reliable bas is in the strength of the forces of peace and the forces of democracy, and in the freedom and independence of nations. 
In terms of strategic weaponry, the Soviet Union is quite convinced that the achievement of parity with the United States is a reality. Hence, Suslov can call for agreements that "are based on the principles of the equal security of both sides and provide no unilateral advantages in the field of strategic missile arms to either side..." 83 Furthermore, the U.S.S.R. appears to be quite ready to utilize this equality as a major factor in formulating its foreign policy, especially as such policies directly pertain to the United States. In the realm of conventional military forces the Soviet Union is equally convinced that its position vis-a-vis the United States is at a level of parity. Thus, while the United States may realize the uselessness of using thermonuclear weapons against a now equal adversary, it is also important, in the Soviet view, that the same assessment be made in regard to conventional military endeavors. The United States, from the Soviet perspective, having realized the insanity of using nuclear weapons, made an attempt "to expand the 'applicability' of military force by strengthening the components of that force that would make possible, while refraining from a nuclear war against the U.S.S.R., to wage limited, so-called local wars with impunity." 84

Yet, as the Soviet Union is fond of reminding the world, the American military endeavor in Vietnam and the eventual victory of the communist forces of North Vietnam brought forth the objective reality of the military ineptness of the United States. Military superiority, conventional and strategic, had always been the ace card used in the formulation of American foreign policy. However, as the Soviets assert, "the war in Vietnam showed that, given the new alignment of forces in the world, this card has been trumped," forcing the United States to 
"understand that military force cannot serve as, so to speak, the 'heart and soul' of all foreign policy, as the logic of the 'cold war' presupposed." 85 Brezhnev can also present the view that the Soviet Union did much to help the Vietnamese in their successful struggle against the United States. As stated by Brezhnev:

The war in Vietnam, for the ending of which the Soviet Union worked firmly and consistently, has ended. Relying on the powerful moral and material support of the Soviet Union and other socialist countries and on the solidarity of all the progressive forces in the world, the patriots of Vietnam have successfully upheld the just cause of freedom and independence. 86

It became quite necessary for the United States to eliminate the Cold War theory of military aggression and use of military force in conducting its foreign policy. In the words of Arbatov:

The course and outcome of the American aggression in Vietnam have shown that in today's conditions the U.S.A. cannot also hope for success in "limited" and "local" wars, on which the American military-political doctrine of "flexible retaliation" pinned its hopes in the late 1950's. The entire course of events in the late 1960's and 1970's has called in question many of the foundations of the U.S. foreign policy course as it was formulated during the "cold war" years. 87

The Soviet Union therefore, is able to conduct Soviet-American detente in the 1970's with what they perceive to be an equal stature vis-a-vis the United States in the military field. Again, this parity in military power can be seen as a prime determining factor in affording the Soviet Union a more flexible and far-reaching detente policy. It is imperative therefore, that the U.S.S.R. sustain this present co-equal position and not allow the United States to re-assert its military superiority. To do so would be to eliminate the very heart of Sovietstyled detente of 1972-1980, and force the Kremlin regime to limit the scope and purpose of its foreign policy. Thus, Brezhnev has repeatedly 
warned that while "we now have fine equipment," it is critical to remember that "we live in an age of scientific and technical progress, when weapons are being improved so rapidly that new forms and systems are often created not just within a year but even within a shorter period." 88 Brezhnev can then logically argue that "stagnation in this (military technology) sphere may be frought with serious consequences. Our scientists, both civilian and military, must constantly think about this and remember it." 89 Defense spending, irrespective of Soviet calls for disarmament, must also be maintained at a high level so as not to risk losing the vitally necessary Soviet-American military parity. As stated by Brezhnev, in regard to defense, the U.S.S.R. will "spend on it exactly as much as is needed for the reliable security of the Soviet Union and for the defense, in conjunction with the fraternal countries, of the gains of socialism, so that potential aggressors will not be tempted to try by force to decide in their favor the historical controversy between the two opposing social systems." 90

It is clear therefore, that Brezhnev stands in a position that is far more advantageous than that which was realized by Lenin. It was impossible for Lenin to achieve his dream of defeating the rations of the capitalist-imperialist world without first achieving a high level of military strength and then fighting his enemies on an equal basis. Brezhnev does not suffer the same handicap. The Soviet Union of today believes that it has realized the goal of military equality, thereby radically altering the rules by which the game of Soviet-American detente is played.

Detente as the preparation for the final East-West war. As mentioned above, the Leninist detente formula was based on the fact that a respite 
was needed so as to prepare for the final cataclysmic confrontation with the West. In Lenin's mind the ultimate goal of the destruction of the worldwide capitalist-imperialist system could not be achieved without waging this fatal life and death struggle. For Lenin the inevitability of this Armageddon was unquestionable. What was questionable was the time when this conflict would take place, and detente was meant to buy as much time as possible before the conflict occurred.

As we have seen, the Soviet Union during the tenure of Leonid Brezhnev has altered this basic dictum of a final full-scale war with the United States. More specifically, Nikita Khrushchev revised this line of reasoning with his theory that inter-camp wars were no longer "fatalistically inevitable." In carrying through with this theme Brezhnev has concluded that while all wars, including nuclear wars, are permissible, they indeed are not inevitable. Brezhnev, as will be seen below has rationalized that "just wars" are completely acceptable and even necessary components of certain "progressive" changes in the world. Yet, the unleashing of a total thermonuclear confrontation with the United States is not seen as a feasible option for the Soviet Union. Brezhnev has often repeated his philosophy that detente "is the path from confrontation to cooperation, from threats and sabre-rattiing to the resolution of disputed questions through negotiations and, on the whole, a reshaping of international relations based on healthy principles of peaceful coexistence, mutual respect and mutual advantage. "9l Moreover, Brezhnev can claim that:

I should like to emphasize that we judge the development of the international situation primarily by the extent to which it is possible to make progress in consolidating peace and eliminating the threat of nuclear war. In our view, definite positive results have been achieved in this area in recent years. 92 
In regard to the United States, Brezhnev asserts that the turn for the better in U.S.-Soviet relations "has, of course, been of decisive importance in lessening the threat of a new world war and in strengthening peace." 93 It has been argued above that the waging of a total nuclear war was not a viable option for the ruling circles in either Washington or Moscow. It was also reasoned that detente could not be viewed properly as a policy that was designed to prevent a thermonuclear war. In the Soviet perception detente would, in fact, as Brezhnev mentioned above, serve as a deterrent to nuclear war. Yet, the lessening of the danger of such a war is not based on the willingness of either side to mutual7y agree not to destroy the other. Rather, it can be argued that it is based on the existence of approximate strategic parity in the realm of Soviet-American thermonuclear capability. Hence, with neither side assured of surviving such a holocaust, it becomes logical to look for other means to settle the dispute. The Soviet Union has opted for detente as such a means, thus allowing for the active pursuit of foreign policy objectives while tempering any American retaliation with the prospects for a devastating and uncertain nuclear war.

It can be reasoned that the Soviet logic here is quite simple. The final military confrontation with the United States is avoidable, and is not an attractive option in that the U.S.S.R. can not be assurred of surviving a thermonuclear war. Should the United States attempt to conduct such a war, however, it too is uncertain of winning, thus allowing the Soviet Union to exploit this uncertainty as a deterrent to hostile American actions. Having confronted the United States with the reality of strategic parity, the U.S.S.R. can then proceed on a course of foreign policy endeavors without resorting to full-scale war and without inviting 
a total thermonuclear response from the United States.

However, while this final showdown with the West was no longer inevitable or desirable, it is still quite possible. The fact that the Soviet Union does not wish to become engaged in a thermonuclear war, will not in itself guarantee that such a war will not be waged. In the words of Arbatov:

It hardly needs to be demonstrated that in today's conditions the prevention of a new world war is becoming a mutual interest of paramount importance. Even the mere awareness of this interest is opening up very broad possibilities for improving relations, especially because the reliable, actually guaranteed prevention of a thermonuclear war requires not only an understanding on the renunciation of conscious attempts to unleash such a war but also a radical improvement in the whole system of international relations.

After $\mathbf{2} 11$, in a world where tension reigns, where hotbeds of military conflicts are smoldering, states can be drawn against their will into an escalation of events in which they may lose control over the situation and a catastrophe will become inevitable. 94

The major cause for the existence of "hotbeds of military conflicts" is, quite naturally in the Soviet view, the aggressive tendencies of the United States and its NATO bloc allies. The United States may have been compelled to reassess its relations with the Soviet Union and to structure them in light of the military might of the U.S.S.R. However, the United States could not be expected to lay down its arms quietly. As stated by Soviet Colonel Sidelnikov, "the peace loving peoples and the world's progressive public cannot fail to reckon with the fact that the aggressive forces of imperialism have not laid down their arms and evidently will not do so for a long time." Furthermore, it is argued that "there is no dearth of adventurers who are capable of kindling a new military conflagration and trying to unleash a new war for the sake of their own selfish interests." 95 Brezhnev can also add a somber view of the 
reality of the present situation even in the era of detente. As stated by Brezhnev:

To be sure, we are realists and cannot help seeing facts of a different order as well. We know all too well that wars and acute international crises are by no means over. There are still acts of aggression in the world, and not all nations

Brezhnev, in writing to an American audience, has attempted to demonstrate the hostile anti-detente attitude that prevails in the United States. In Brezhnev's words:

Such (American) readers have come under the influence of political forces bent on sabotaging detente. Actively using the means of manipulating public opinion, these forces present their own private interests as the interests of the nation. They are busy creating log jams in the way of agreement between our countries on crucial questions of arms limitation and the preparation of conditions for transition to disarmament. 97

The Soviet view of the possibility of a large scale thermonuclear war with the United States is closely connected to the Soviet theory of the "alignment of world forces," as well as the Soviet belief in the attainment of strategic equality with the United States. As outlined above, the latter two components, when viewed together, formed the basis for the United States being forced to accept detente. The new variable, that of an American-initiated thermonuclear war, is a result of the United States making a desperate attempt to counteract the inalterable process of the alignment of world forces and to thwart the military might of the Soviet Union. This belief is accurately summarized by Brezhnev:

The point is that the aggressive circles of the capitalist world are reacting to their defeats in social battles, to the loss of colonial possessions, to the abandonment of capitalism by more and more countries, to the successes of world socialism and the growing influence of the Communist Parties in the bourgeois states - to all these trends - with a feverish buildup of military preparations... By relying on these "positions 
of strength," imperialism hopes to retain the possibility, which is slipping from its hands, of ordering other
countries and peoples around.98

By reacting in such a manner the United States, according to Soviet spokesmen, might well attempt to force the issue in regard to the ultimate victor in the struggle between the two diametrically opposed socio-economic systems. Claiming that the United States is "hard pressed" to react, Marshall Grechko could still claim that "they are in every way stepping up their opposition to the process of detente, and they have not abandoned their plans to resolve the historic argument between capitalism and socialism by force of arms." 99

The specter of massive American arms buildup is then raised as the barometer for measuring the still-existent aggressive tendencies of capitalism-imperialism. As Brezhnev noted:

We also have no right to forget that, in conditions of the easing of international tensions, processes that constitute material preparations for a world war are continuing and even intensifying.

The military budgets of the countries of the North Atlantic bloc are increasing by $\$ 2,000,000,000$ to $\$ 3,000,000,000$ annually, and behind these figures are more and more new types of weapons of destruction - new and increasingly destructive nuclear bombs and warheads, new and increasingly powerful missiles, tanks, and planes, warships and submarines. The qualitative improvement of weaponry has assumed unprecedented scope. 100

Thus, while the Soviets claim that they want no part of a Cold War posture, and certainly want no part of a nuclear war, they must still, in their words, recognize that, "the possibility of a retrograde movement to the 'cold war' has still not been ruled out, although each new success of the peace policy makes the changes that are taking place more and more durable and stable." 101 What this translates to in the Soviet viewpoint is the need "to maintain vigilance and to give a firm rebuff 
to all the schemes of imperialist reaction." 102 Hence, the Soviets can argue that detente, while eliminating the inevitability of a new world war, requires the continued buildup of military might in order to ensure that such a war is not launched by the United States. The Soviet Union in short, must be ready and willing to wage full-scale war if necessary. In the words of Sidelnikov:

Our military-theoretical thought believes that as long as this complex and difficult problem remains unsolved and the aggressive forces of imperialism and various kinds of adventurers continue to exist and operate, it will still be necessary to be ready to wage war using any means of armed struggle. 103

Brezhnev can claim in this regard that "of course we are improving our defenses." "We cannot do otherwise," according to Brezhnev, because "we have never yielded, and shall never yield, in matters of our own security or the security of our allies."104 In Brezhnev's view, the need for increased defense expenditures is a direct result of the imperialist-inspired arms race. As stated by Brezhnev:

The military preparations of the capitalist states are compelling the socialist countries to allocate the necessary funds for defense, diverting them from civilian construction to which we would like to dedicate all our efforts and all our material resources. Dozens of newly independent countries are also being drawn into the orbit of the arms race, which, of course, is prompted by the threat to their independence posed by imperialism now in one part of the world, now in another. 105

It is clear therefore, that continued qualitative and quantitative improvements in the Soviet military arsenal within the overall framework of detente are quite necessary in the soviet view. The necessity is dictated, according to Soviet spokesmen, not by the desire to wage nuclear war but rather, by the need to both maintain the vital parity in strategic arms and to be prepared for any American attempt to unleash a new world war. Throughout this process the U.S.S.R. continually 
bemoans the fact that the United States maintains the paradox of increasing its military budget while signing accords with the Soviet Union aimed at limiting arms buildups. Thus, a Pravda editorial can cite the logic of the U.S. Senator Edward Kennedy who "pointed out the discrepancy between the Pentagon's desire to expand U.S. strategic forces and the spirits of the agreements signed by the U.S.S.R. and the U.S.A. and currently in effect between them."106 At the same however, the Soviet position, exhibiting a similar paradox, is quite acceptable. As stated by Grechko:

Therefore, our Party, in pursuing its active peaceloving foreign policy, constantly provides it with increased vigilance and shows tireless concern for strengthening the country's defense capability and for increasing the combat might of the Armed Forces, outfitting them with up-to-date military material and weapons and improving their combat readiness...107

By way of summary it can be noted that Lenin was thoroughly convinced of the inevitability of a final all-inclusive war with the West, but that Brezhnev is convinced that such a conflict can be avoided. In short, for a number of reasons Brezhnev would prefer not to opt for a war with the United States. Rather, he has chosen what the U.S.S.R. feels is a more reasonable alternative, the gradual, though forcefur, policy of incremental changes in the East-West balance through the detente strategy.

Detente as a reaction to a potential anti-Soviet al7iance. As pointed out above, Lenin was obsessed with the fear that the capitalistimperialist nations would, in their own best interests, form a military alliance aimed at crushing the Soviet state. Lenin reasoned that his enemies, once freed of their involvement in World War I, would naturally turn their combined resources toward their common foe. Detente, in this 
respect, was aimed at reducing the threat presented to the west and at precluding such a joint enterprise by the imperialists.

In many respects the threat of this potential anti-Soviet alliance has changed considerably. To be sure, the United States and the Soviet Union each has a bloc of military allies that could be counted on for assistance in the time of war. Yet, as far as the Soviet Union is concerned the predominant imperialist military adversary that it must confront is the bastion of capitalism-imperialism and the "other camp's" most formidable nation, the United States.

In the Soviet view, a military onslaught against the U.S.S.R. could only be effectively waged with the direct involvement of the United States. A military attack by the United States would obviously be of great concern to the U.S.S.R., whether the United States acted alone or in conjunction with its military allies.

The Soviet Union is less seriously concerned with a Western military coalition than Lenin was as a direct result of two previously mentioned variables in the detente formula. That is, the U.S.S.R. is no longer an "oasis" isolated from the rest of the world by virtue of its socialist form of government, and no longer suffers a severe military inferiority in regard to the United States. Thus, the fear of a Western coalition can be seen as being nearly synonymous with the concomitant possibility of the United States waging a new world war. Having become desperate in the face of the reality of the alignment of world forces in favor of socialism, having recognized the growing military might of the Soviet Union, and realizing the futulity of stopping the unalterable movement of the world toward socialism, the United States in conjunction with its military allies, might well resort to nuclear war. 
As will be mentioned below, the Soviet Union has attempted to make a unified Western coalition, military, economic, or political in nature, a difficult task for the United States to achieve. Detente with the U.S.S.R., as cited earlier, is a more attractive option for some West European nations than it is for the American government. Accordingly, some Western governments are unwilling to join the United States in a unified anti-Soviet posture of any kind. In the military realm the U.S.S.R. has by virtue of its achievements through detente, tried to make an effective anti-Soviet coalition less realistic. In the words of Andropov:

Unshakable guarantees that no aggressor or coalition of aggressors will be able to gain the upper hand over socialism have been created and are growing stronger year by year. 108

However, the Soviet Union feels that the attempt to create such a bloc of anti-Soviet and anti-detente forces is being made by many reactionary leaders in the West. While the Soviets claim that such a coalition could not prove to be effective militarily, the U.S.S.R. can still acknowledge the possibility of creating an anti-Soviet front:

We can see that today an international bloc of the enemies of peace and detente is being formed. Along with the military-industrial complex, imperialist reaction, fascists and colonialists, it includes the Maoist leadership of China. 109

The role of the People's Republic of China in relation to the Soviet perception of and motives within detente is subject to debate. At any rate, there is evidence to suggest that Soviet concerns with the C.P.R. provided a major stimulus for the pursuit of the latest variation of detente. As mentioned above the Soviet Union may well have feared that a U.S.-China detente would virtually isolate the Soviet Union from the world's other major superpowers. As stated by Arthur M. Schlesinger, Jr., 
the Soviet Union developed an "obsession" with China which:

...led to an urgent need or an urgently felt need both to tranquilize the European front and to block any consolidation of a Chinese-American connection directed against the Soviet Union. The Russians doubtless anticipated that after the cultural revolution China for its part would be equally determined to block any Soviet-American relationship directed against itself, and that the chinese would try to break out of diplomatic isolation. 110

Similarly, Hans J. Morgenthau has noted that the China question is the most important of the three basic reasons that prompted the soviet Union to pursue a detente with the United States:

First, they are engaged in a struggle with China which both sides take with extreme seriousness... This being the case, no country can afford a two-front confrontation, let alone a two-front war. In the measure that the relations between the Soviet Union and China become aggravated, the Soviet Union has a vital interest in mitigating the tensions with the West. Here is the first reason for detente. 111

George Schwab has also noted that ever since China "emerged as a troublesome neighbor and one whose nuclear arsenals and delivery systems are growing and improving, Moscow has been forced for tactical reasons to open more channels of communication with the West." 112 The reason for these expanded communications, of course, is to preclude the possibility "of a military invasion of the Warsaw pact countries, including perhaps the European part of Russia, at a moment when Moscow may find itself in a military confrontation with Peking." 113

In a traditional military sense, there would seem to be ample evidence to support the argument that the U.S.S.R. wanted to avoid a two-front confrontation. Large-scale border clashes between Soviet and Chinese troops had been reported for some time and the war of polemics between Moscow and Peking was continuing. Thus, it would seem plausible that the Soviet Union would be concerned with reducing tensions on its Western border so as to avoid being trapped in an East-West crunch 
should the Chinese decide to open full-scale hostilities.

The C.P.R., however, presents the Soviet Union with an equally important problem in regard to the pursuit of Soviet objectives within the framework of detente. It will be argued below that the Soviet Union has maintained the goal of the worldwide victory of socialism as an integral part of its detente strategy. It will also be reasoned that the U.S.S.R. hopes to achieve this final goal through the use of the strategic objective of continuing the growth of the alignment of world forces in favor of socialism. The specific strategy that the Soviets will use, as will be demonstrated, is the alignment of "third world" or developing nations into the socialist camp, through the anti-imperialist, pro-socialist national liberation movement. It is here that the Soviet Union must be concerned with the C.P.R. and its revolutionary activities. In the first place, the Chinese appear to be no less bellicose than the Soviet Union in regard to the primacy of the goal of the ultimate victory of socialism. Secondly, the U.S.S.R. has long been forced to compete with China for influence in the developing nations and in some Asian nations under communist party control. Finally, in the wake of the 1972 U.S.-China rapprochement, it has become clear that the C.P.R. has been intent on branding the Soviet version of revolutionary support as being militaristic in nature and of serving the cause of Soviet national interests, specifically in the form of military expansion.

Thus, it would seem incumbent upon the Soviet Union to preclude any damaging U.S.-China detente and to engage in a meaningful U.S.-Soviet detente so as to avoid a two-front military confrontation. It would also appear to be of necessity for the Soviet Union to isolate the C.P.R. from the revolutionary movement in the "third world" and to denounce the 
Chinese as "counter-revolutionaries" and "reactionaries." Thus, in his

keynote address at the 24 th C.P.S.U. Congress (a report that was later acclaimed as the Program of Peace - see above) Brezhnev asserted that:

About our relations with the Chinese People's Republic. The Chinese leaders, as is known, have put forth their own special ideological-political platform, which is incompatible with Leninism, concerning basic questions of international life and the world Communist movement and have demanded that we renounce the line of the 20th Congress and the C.P.S.U. Program. They launched intensive hostile propaganda against our party and country, made territorial claims against the Soviet Union, and even brought things to the point of armed border incidents in the spring and summer of 1969.114

Brezhnev has claimed that the Soviet Union has firmly opposed the Chinese attempts to "distort the teaching of Marxism-Leninism, to split the international Communist movement and the ranks of the fighters against imperialism." 115 Consequently, Brezhnev has been stern in his rebuff of any anti-Soviet propaganda presented by the Peking regime:

...We, of course, cannot fail to see that the anti-Soviet line in China's propaganda and policy is continuing and that the Ninth C.P.C. Congress firmly established this hostile course toward the Soviet Union in its decisions.

What can be said in this connection?

We resolutely reject the slanderous fabrications concerning the policy of our party and state that are being disseminated from Peking and instilled in the Chinese people. 116

This evidence would suggest that the Soviet Union is quite concerned with the C.P.R., and that this concern is expressed most vividly in the area of Soviet-Chinese competition in the revolutionary movement in the developing nations. Thus, while rejecting Chinese polemical attacks against the Soviet Union, Brezhnev outlined this competition in the form of anti-Chinese attacks:

In the period under review, attempts from various sides to attack Marxism-Leninism as the ideological and theoretical basis for the activity of the Communist movement became very acute. The Chinese leadership shifted to the creation in a 
number of countries of schismatic groupings under the signboard of so-called "Marxist-Leninist Parties," obviously international Communist movement a counterweight to the

That this policy line did not diminish during the actual implementation of the Peace Program is evidenced by remarks made by Brezhnev during his keynote address at the 25th C.P.S.U. Congress. Here, Brezhnev claimed that:

Relations with China are, of course, a special and separate question. The policy of its present leaders is openly directed against most of the socialist states. More than that, it lines up exactly with the positions of the world's most extreme reactionaries - from militarists and enemies of detente in the Western countries to the racists of South Africa and the facist rulers of Chile. This policy is not only completely alien to socialist principles and ideals, in effect it has become an important reserve for imperialism in its struggle against socialism. 118

In regard to the possibility of an anti-Soviet coalition during the Brezhnev era, the C.P.R. has therefore, played a central role in increasing the possibility of such. This is quite different from what Lenin saw. Lenin felt that an imperialist, and certainly not an imperialistsocialist, coalition against the Soviet Union was a very definite possibility. Brezhnev, however, must be concerned that an imperialist-Maoist anti-Soviet coalition is a potential reality.

Brezhnev, apparently aware that a similar fear may be realized in Peking is careful to assert that a U.S.-Soviet detente will not adversely affect the Chinese. In Brezhnev's words:

To all who are aware, if only slightly, of the actual course of events, of the nature of the development of SovietAmerican relations, it is absolutely clear that the improvement of Soviet-American relations is in no way detrimental to the interests of any third countries. 119

In addition, Brezhnev has also stated that:

It is often said that the idea of creating and ensuring security in Asia by collective effort is directed agairist 
China and all but pursues the perfidious aim of "surrounding" or "isolating" China. But these contentions are either the product of morbid suspicion or a reluctance to face the
facts .120

Again, the main fear that the Soviet Union expresses in a military sense is that the West, hopelessly frustrated by Soviet and Soviet-inspired successes, may react in an aggressive manner. Brezhnev has often claimed that detente has "inspired and strengthened the forces of peace and progress and heightened their prestige and influence among the masses." 121 Yet, as Brezhnev is also quick to point out:

But it has also alerted and activated the forces of reaction and militarism, those who would like to drag Europe and the whole world back to the time of the cold war, of teetering on the brink of nuclear catastrophe. It has alarmed those who are growing rich on the production of tools of death and destruction, who cannot conceive of any political career other than whipping up "crusades" against the socialist countries, against the communists...122

The Soviet Union is also quite aware that this reaction is directed mainly at the U.S.S.R. itself. As Brezhnev has claimed:

...imperialism's aggressive forces and their yes-men are again putting out the hackneyed myth about the notorious "Soviet menace," which allegedly looms over the Western countries. Absurd assertions grossly distorting the policy of the Soviet Union and other socialist states are persistently disseminated - by the mass information media and frequently by figures holding prominent positions.

To summarize, it can be stated that the Leninist fear of an anti-Soviet coalition has been changed, but certainly not eliminated, in the thermonuclear world of the 1970's. Yet, while the specific details of this phobia have been altered, the logic in this variable of Lenin's detente remains unchanged. Lenin had argued that the greater the threat posed by the Soviet state, the greater would be the potential for the West to jointiy crush the menace that threatened it. Brezhnev has reasoned in a similar fashion. The greater the threat posed by the U.S.S.R. 
in regard to the world balance of power, Soviet military might, and dissemination of socialism, the greater would be the risk of a reckless anti-Soviet thrust by the United States (in conjunction with its allies and perhaps, the People's Republic of China). In both cases detente has been utilized by the Soviet Union as a means to forestall such reactions by the West. Lenin used detente as a means to convince the West that coexistence with, and not the elimination of, the Soviet state would be in its own best interests. Similarly, Brezhnev through the selling of the Peace Program has shown the West in general, and the United States in particular, that detente with the Soviet Union is the only feasible alternative open to them.

Detente as a means for securing Western economic assistance. One of the major strategic objectives of the Leninist detente was the acquisition of much needed Western assistance in the reconstruction of the devastated Soviet economy. With the ravages of World War I came the stark reality that the Soviet industrial, agricultural, and overall economic base could not be restored without foreign support. As outlined above, Lenin knew all too well that such support could best be provided by the imperialists, and most notably by the United States.

A number of aspects of Soviet-American relations have changed since 1917, and the Soviet Union has made impressive gains in many areas during that timespan. Yet, in the realm of economic relations, the Soviet Union under Brezhnev, has found itself in a situation where its relations with the capitalist world have not changed since Lenin's time. True, the Soviet Union did not suffer from a war-torn ravaged economy from 1972-1976. At the same time however, the U.S.S.R. was, as always, plagued with pressing problems in both its industrial and 
agricultural sectors. In fact, it can be stated that one of the common strands of U.S.-Soviet relations from their very inception is the Soviet need for Western, and particularly American, economic assistance in helping to correct Soviet economic deficiencies.

The reliance on American trade and expanded economic contacts with the United States represents one of detente's more controversial aspects. The infusion of scientific, technological, and economic expertise from the United States has also afforded the opponents of detente a logical and formidable argument. Both Lenin and Brezhnev have outwardly claimed that the final victory of the forces of socialism and the ultimate defeat of the capitalist system are their main objectives. At the same time they both asserted that American economic assistance is a necessary prerequisite for achieving that goal.

Reduced to its simplest form the logic employed by Brezhnev, as defined in detente, reads as follows. The Soviet Union has achieved strategic parity with the United States and uses such as a major pillar for its relations with the West. To achieve and maintain that parity, the U.S.S.R. has drained much of its economic resources, thus postponing the construction of a "new society" and creating a host of domestic concerns. In order to reduce the burden placed on its economy the Soviet Union must achieve a Soviet-American arms reduction accord, and, simultaneously engage the assistance of the United States in solving its economic problems.

It was pointed out above that Brezhnev's economy was not suited for an intense level of military, scientific-technological, and economic competition with the United States. Brezhnev was compelled to reduce the tenacity of this competition by offering a peaceful and cooperative 
posture to the United States. It was also shown that Brezhnev would like nothing better than to re-channel part of his military-defense allocations to more "constructive" domestic areas. Yet, to do so would require a concrete arms Iimitation agreement with the United States, and negotiations on that front are more often than not at an impasse. It was also mentioned that the sustainment of strategic parity and the matching of the United States in both qualitative and quantitative military improvements is of paramount urgency for the U.S.S.R. Hence, a logical option for Brezhnev is to employ the strategy of detente that on one hand necessitates massive military spending with which to threaten and contain the United States, and on the other calis for American support to buttress the Soviet economy so that the military threat can be sustained and domestic discontent quieted.

The Soviet Union has made no attempt to conceal the fact that economic relations with the West form an integral part of the detente formula. Brezhnev has often pointed out that "economic and scientifictechnical ties with the capitalist states are consolidating and broadening the material base of the policy of peaceful coexistence." 124 Furthermore, Brezhnev has cited the fact that the Soviet Uniun sees "foreign economic relations as an effective means facilitating the accomplishment of both political and economic tasks." 125

The subject of Soviet-American trade and economic relations in general between the two countries are subjects too broad in scope to cover in a comprehensive fashion here. The Soviet line of reasoning however, as sketched above, is capable of being summarized in a fairly concise manner. The belief in Moscow is that the "Soviet Union attaches a great importance to the expansion of foreign trade, including trade 
with the U.S.A.," and that such relations "are becoming a more and more promising reserve for increasing the economic effectiveness of the U.S.S.R.'s national economy..." 126 The U.S.S.R. Minister of Foreign Trade, Patolichev in analyzing Soviet trade with the West, summarized those relations as follows:

...our country receives an opportunity to make fuller and more rational use of its own resources and possibilities and at the same time to acquire, by way of commercial exchange, goods of other countries that are not produced in our country or whose production would cost more than it does to import them. Thus, foreign economic ties offer a more efficient solution to a number of problems arising in the course of

Brezhnev, in addressing an American audience, can show the scope of the Soviet-American economic relations that he would hope to see. In the words of Brezhnev:

... Now, I think we all agree that it isn't sufficient merely to overcome the anomaly, generated by the "cold war," of the complete freezing of Soviet-American trade. Today 1 ife faces us with much bigger questions. I have in mind, first of all, such forms of economic relations as stable, large-scale ties in a number of economic branches, and long-term scientific and technological co-operation, something that in our age is of great importance. 128

Brezhnev can also show that while the expansion of economic cooperation is very important, it cannot be based on ideological relaxation or "liberalization." As stated by Brezhnev:

An important factor in consolidating the positive political changes in the international arena and in creating a material basis for a lasting peace is the al1round development of economic and scientific-technical links. It meets the interests of all states and all peoples. However, there are circles in the West that hope to obtain from us, in exchange for such links, political and ideological concessions. That is a futile undertaking. 129

In discussing the importance of expanding Soviet-American trade, Brezhnev has claimed that the future successes of detente are, in many ways, dependent on the success achieved in this area. Thus, in his speech 
at the Second Moscow Session of the U.S.-U.S.S.R. Trade and Economic Council, Brezhnev stated:

We feel that the U.S.-U.S.S.R. Trade and Economic Council is making a substantial and constructive contribution to the development of a very important field in the relations between our states and peoples.

Without further advances in this area, which represents the material foundation, as it were, for the vast edifice of SovietAmerican peaceful co-operation and good-neighborliness, much of what has been accomplished through joint efforts in 1972, 1973 and 1974 stands the risk of being weakened.130

In describing the policy of detente the Soviet Union is careful to point out that it is a continuation of the policy established by Lenin and that there is a perfect continuity from Lenin's Decree on Peace to Brezhnev's Peace Program. In the field of Soviet-American economic relations the U.S.S.R. is fairly accurate on this account. Contemporary Soviet spokesmen assert that:

The Soviet Union's principied attitude toward the use of external markets, including the U.S. market, for the needs of socialist construction was defined by V.I. Lenin. Back in October, 1919, Lenin said: "We are decidedly in favor of an economic understanding with America - with all countries, but especially with America."131

The U.S.S.R. can conclude this reasoning with claims that are quite reminiscent of those made by Lenin. Soviet spokesmen assert that this cooperation with the United States "will make it possible for the Soviet Union to enlist additional material and financial resources in accelerating the pace of socialist construction; this will not only satisfy the country's growing domestic requirements but will also pay for American participation in this construction." 132

By its own admission therefore, the Soviet Union is seeking American aid in the socialist construction of the Soviet Union, which would further heighten the demise of the United States. The payment for this would be "mutually advantageous" agreements that would be 
profitable for American business enterprises. Hence, by exploiting both the naivité and greed of the United States, the Soviet Union would hope to reap tremendous benefits.

In summary, it can be stated that no significant changes have manifested themselves in this area from Lenin to Brezhnev. Lenin and Brezhnev both recognized the necessity of utilizing American economic assistance and both added this to their respective detente formulas.

Detente as a means to exploit antagonisms within the capitalist-imperialist world. Lenin realized full well that in order to postpone any potential anti-Soviet coalition among the imperialists he would need to exploit the antagonisms and contradictions that existed among them. By allowing the capitalists to fight among themselves, Lenin reasoned that an alliance aimed at crushing the Soviet state would be an impossibility. Hence, it was necessary for Lenin to continually point out the intense conflict of interests and contradictory needs of the West, and wherever possible, to incite feuds and conflicts among his enemies.

It can be demonstrated that it is equally important for the Soviet Union under Brezhnev to highlight and exploit any fissures that it may find in the capitalist-imperialist structure. It will be argued below that Brezhnev finds the necessity of utilizing discord within the West because of his realization that an effective economic and political coalition aimed at thwarting the goals of the U.S.S.R. would pose a very serious problem. A complete return to the cold war by the entire West, under the leadership of the United States, in the Soviet view, would do irreparable damage to the objectives, both foreign and domestic, that the Soviet Union has set for itself. Thus, it is quite imperative for Brezhnev to show the lack of unity among America's al7ies, and to claim 
that their internal contradictions and conflicting interests are greater than the threat posed by the Soviet Union. As noted above, the U.S.S.R. is still concerned that a coalition of "anti-Soviet aggressors" may be attempted by the West, or the West and China. The West, under the onslaught of the advances of socialism, will continually attempt to create such an alliance, as Brezhnev has often claimed:

Incidentally, our common class enemy, the international bourgeoisie, shows a good many examples of the international coordination of its own actions in the struggle against revolutionary forces. Wherever the exploiter system is in jeopardy, wherever the forces of national and social liberation and democratic forces gain the upper hand in the struggle, imperialism is making feverish attempts to coordinate its counter-attacks - there are a good many examples of this in our days, in Europe, in Africa and in other places. 133

It is incumbent upon the Soviet Union therefore, to preclude any successful coordination of this nature to the point that it will serve as a deterrent to Soviet actions. In an attempt to do so the U.S.S.R. has intensified its progaganda efforts aimed at publicizing the growing discord among the nations of the West. Thus, Brezhnev can repeatedly claim that "inter-imperialist rivalries and discord within the Common Market and within NATO have intensified," and that "the growing power of the international monopolies have made the competitive struggle still more ruthless."134 This competition, in the soviet view, then manifests itself in new areas of contradictions and antagonisms among the imperialists. As summarized by Brezhnev:

The capitalist countries' governments are making one attempt after another to smooth out the contradictions and to reach accords on joint measures to overcome the crises. But the nature of imperialism is such that each country strives to obtain advantages at the expense of the others, to impose its own will. Differences come to light in new forms, contradictions flare up with new force. 735

The Soviet Union has gone to great lengths to show the nations 
of the West that these contradictions exist and are intensifying. In particular, the U.S.S.R. has highlighted what it sees as an intensification of the discord existing between the United States and its allies in Europe. Soviet spokesmen have claimed, for example, that "the situation in the Middle East has clearly shown the sharp intensification of differences between the United States and its European allies."136 Here, the U.S.S.R. can cite the fact that:

...American circles have been accusing their NATO partners of "leaving the U.S.A. in isolation,"... Western Europe, for its part, is rebuking the U.S.A. for acting without advance consultation with its allies for rendering support - above all military support - to Israel, even while using other countries' territories for the shipment

The Soviet Union has also taken advantage of the energy crises in the West to show that the antagonisms within imperialism are intensifying. Thus, the U.S.S.R. can claim that the energy problem has demonstrated the "American 'monopoly circles' attempt to exploit the current fuel shortage in Europe for the defense of their economic and political positions there." 138

Much of what the Soviet Union sees as fertile ground for sowing discord among the nations of the West is a result of specific economic crises that plagued the capitalist system during this period of detente. The energy crisis and fuel shortage problem was touched upon in regard to Europe's antagonisms with the United States. However, from the Soviet perspective, this is but one of many specific contradictions and crises that are confronting the United States. The Soviet Union has let it be known that the crises within the United States itself are of great concern to the West and highlight anew the inherent contradictions of the capitalist-imperialist system. It has been noted that these 
conflicts have "emerged with special force" not only in the realm of "serious foreign policy difficulties" but also in the area of "inflation and unemployment, the balance of payment deficits, the undermining of the position of the dollar and the difficulties in the world market."139 These acute difficulties then, in the words of Arbatov, translate into severe social problems, including:

...the problem of poverty in the richest capitalist country, the problem of the black population of America, which is subjected to especially cruel oppression, the crises and decay of the big cities, the monstrous crime rate, the decline in morals, the growing hostility of the younger generation to traditional bourgeois "values," attitude toward nature.?

Brezhnev can then paint a picture of a capitalist society that is void of human rights. As stated by Brezhnev:

...nearly a hundred million people are at present unemployed in the nonsocialist countries. Many capitalist states violate the rights of national minorities and foreign workers, and the right of women to equal pay for equal work. This is probably why many Western powers have not yet subscribed to international covenants establishing the social and political rights of man. 141

These internal contradictions are then translated into antagonisms within the imperialist camp as a whole. Brezhnev has stated that "perhaps never before in recent decades have the crises of bourgeois democracy and the progressive internal decay of the political machinery of capitalist rule been so obvious." 142 Then, as Brezhnev states, "in conditions of these crisis phenomena, which are inevitable and stem from the very nature of capitalism, an increasing aggravation of the economic and political contradictions among various capitalist states and their groupings is taking place..." 143

Regardless of the causes, the Soviet Union has pointed out a number of different crises, contradictions, and tensions that exist within 
the capitalist world, which the U.S.S.R. is quite willing to exploit. "The processes of international detente and the bankruptcy of the antiSoviet, anticommunist 'cold war' myths" it is claimed, "are facilitating the development of crisis phenomena in the military-political blocs and groupings created by the imperialists, which are directed against the national-1iberation movement." 144 Soviet spokesmen can then scan the globe and paint a glowing picture of conflicts among the alliances formed by the capitalist-imperialist world:

Already there is sufficient reason to talk about the decline of SEATO...

Fissures have also appeared in the edifice of another pro-imperialist grouping - the Asian and Pacific Council (ASPAC)...

These are difficult days for CENTO, although recently imperialist circles have been making intensive efforts aimed at enlivening this organization...

The Organization of American States (O.A.S.) is going through a profound crisis... 145

It was mentioned earlier that the Soviet Union could not sustain a lengthy and intensified economic and military competition with the United States and still hope to achieve any measure of success in either the foreign or domestic realm. It can also be reasoned that the U.S.S.R. could not endure such a posture with the entire West for a long period of time. Hence, detente has been sold individually by Brezhnev to a number of Western nations. Should the United States withdraw from a strong detente posture with the U.S.S.R., the Soviets reason that the economic and political advantages with America's allies could still accrue to the Soviet Union. Thus, Brezhnev, in analyzing the harm done by anti-detente forces, can claim that:

They managed to prevent the U.S. government from honoring its promise to end discrimination against the Soviet Union in the fields of trade and credit. As a result the Soviet Union turned to other markets; its trade with other Western 
countries grew appreciably, while U.S. foreign trade suffered damage that could easily have been avoided. 746

To briefly look ahead, beyond the period of 1972 to 1976 , it can be shown that detente has reaped some benefits in this area for the Soviet Union. The Soviet invasion of Afghanistan drew sharp criticism from the Carter Administration, while calls for an end to detente, economic boycotts, and non-participation in the 07ympic Games were made by American spokesmen. Yet, in the face of American requests for a unified anti-Soviet posture among its allies, many western governments found it unwise to strongly denounce the U.S.S.R. and to participate in any joint anti-Soviet activity whether it be economic, political, or athletic.

Thus, the "divide and conquer" syndrome employed by Lenin, although changed by virtue of the means by which to conquer, has persisted as a variable in the detente formula of Brezhnev. Lenin hoped to exploit inter-capitalist rivalries as a means to postpone an onslaught against the Soviet state by the imperialists. Brezhnev, it can be argued, has hoped to exploit these differences as a means for solidifying detente and for precluding a total relapse into the costly Cold War years.

Detente as a means for achieving the firial victory of socialism. The single most important factor in the formulation of detente by Lenin was the fulfillment of his most sacred duty; the achievement of the worldwide victory of socialism and the concomitant final and total defeat of the capitalist-imperialist system. Lenin had told us that the two opposing systems could not survive together for a long period of time, that in the end one or the other must triumph by destroying the 
antithetical system. The realization of this triumph, for which detente was created, remained, in this writer's view, as the primary motivating force for Lenin throughout his lifetime.

While many of Lenin's eight detente components have been altered over the years, the goal of worldwide communist domination has not changed. The timing and the means of realizing that objective may have been revised, but the objective itself, the final victory of socialism and the complete collapse of capitalism-imperialism, has not been modified. Moreover, Brezhnev and other Soviet spokesmen have told us that recent events have manifested the irreversible nature of the march to a worldwide socialist victory. The U.S.S.R. is quite confident that the benefits of detente, the growing might of world socialism, and the decay of the capitalist system are realistic, objective criteria that clearly demonstrate the favorable position of the Soviet Union in regard to achieving its ultimate goal. Hence, Brezhnev can claim that:

...the Soviet Union's international position has never been stronger. The security of the Soviet people is more reliably ensured than ever before. Our people are working under the banner of peace and are carrying on the struggle for peace in the cause of the emancipation of labor. 147

Suslov has also made it clear that the final victory of socialism is the ultimate goal of world communists. In Suslov's words:

In struggling for democracy and the satisfaction of the working peoples' economic and social demands, the Communists never forget about the ultimate goals of their struggle - the elimination of capitalism and the establishment of a new, just socialist system. The ideas and policies of reformism and the theories of class cooperation with the exploiters have always been rejected and continue to be rejected by the Communists. 148

Many of the eight detente variables analyzed here also point to a picture of confidence for the U.S.S.R. in regard to the final victory of socialism. In the first place, the Soviet Union is no longer an 
oasis of socialism in a world dominated by the forces of imperialism.

The alignment of world forces in favor of socialism, the consolidation of power by the socialist commonwealth, and the successes of communist parties in the capitalist world have all made the world of imperialism, and not socialism, the minority system in the East-West balance of power. The Soviets also feel that the achievement of strategic parity and overall military equality have made the Soviet Union, and thereby the entire socialist world, a formidable adversary to the West. It has also afforded the Soviet Union an unprecedented opportunity to further shift the balance of power to the socialist side. Finally, the crises and antagonisms in imperialism have, in the Soviet view, done much to further hasten the demise of that system, and make socialism a far more attractive and realistic alternative. Brezhnev has often repeated his belief that the Soviet Union is watching over the unstoppable march of socialism and the simultaneous decline of capitalism. In Brezhnev's words:

The ideological political crisis of bourgeois society is intensifying. It afflects the institutions of power and the bourgeois political parties and shatters elementary moral norms. Corruption is becoming more and more open, even in the highest levels of the state machinery. The decline of spiritual culture is continuing, and crime is on the increase. 149

The crises of capitalism, in conjunction with the further spread and strengthening of socialism, is seen by the Soviets as a realistic gauge for measuring the success of the ultimate communist goal. However, this goal, while attainable, is still subject to the terms of the new detente, i.e., a gradual victory over capitalism within the parameters of a "peaceful" erosion of the capitalist system. In the words of Brezhnev: 
The Communists are by no means predicting the "automatic collapse" of capitalism. It still has considerable reserves. However, events of recent years confirm with new force that capitalism is a society without a future. 150

In the Soviet view the United States has pursued goals and objectives that, while anti-socialist in nature, lack any long-term philosophical objectives and are concerned with more limited imperialist goals. The U.S.S.R. claims that "an important feature of Soviet foreign policy is that it organically ties up the burning issues of the day with long-term problems and main goals" which, it is stated, "makes it possible to overcome the narrow bounds inherent in the policy of the capitalist countries, a policy which so often is being guided by purely pragmatic considerations." 151 From the Soviet Union's perspective, the goals of Soviet foreign policy do not lack such limited objectives, but are guided by the desire to achieve the ultimate long-term victory. Thus, the Soviets can claim that:

...As to its consequences, the implementation of our foreign policy programme designed for a long historical period will be tantamount to a major victory of the forces of peace over the forces of aggression and war. It will also radically alter the entire structure of international relations. It is only natural that such an aim can be achieved only through struggle for a stage-by-stage implementation of the corresponding tasks and only by overcuming the stubborn resistance put up by the aggressive imperialist circles interested in preserving and fanning the hotbeds of tension and conclict, and in maintaining the atmosphere of a war danger. 152

Brezhnev has often claimed that the objectives of Soviet foreign policy are not determined by any short-term or temporary concerns. Thus, Brezhnev can refer to the "consistent and unchanging course of the Soviet Union in foreign policy, a course for the peaceful coexistence and co-operation of states, irrespective of differences between their social and political systems, a course for detente, a course that is unaffected 
by momentary considerations of expediency. "153 Brezhnev has also claimed that:

For us Soviet people the active struggle for peace is not a temporary task dictated by the moment. It is our principled, deliberate, and consistent policy, which we pursue in fraternal unity with all the countries of the socialist community.

With great insight into the future of social development Marx wrote that when the working class builds its own socialist, society, its "international rule will be Peace, because its national ruler will be everywhere the sameLabor." 154

The ultimate objective of detente for Brezhnev is therefore, identical to that of Lenin. Lenin may have been more impatient than Brezhnev, and may have wanted detente to afford him the time by which to prepare himself for the destruction of capitalism. Yet, Brezhnev, while delaying the attainment of this goal, and eliminating a total war as a means for success in this endeavor, has not lost sight of this most basic and all-encompassing objective. Thus, Brezhnev can assert that:

We shall continue to wage a vigorous struggle for international detente, for the elimination of hotbeds of war danger, for an end to the arms race. We shall continue to administer a resolute rebuff to those forces that want to reverse world development. We are convinced that our rightful cause of the struggle for peace and social progress will triumph. 155

\section{The Limitations of Detente}

The evidence cited to this point would suggest that the policy of detente as defined by Brezhnev has the final victory of socialism as its main objective. Yet, as Brezhnev has pointed out, the attainment of this goal will not be realized immediately as the forces of imperialism will not quietly lay down their arms, modify their inherent aggressive nature, or willingly accept the demise of their system in the face of 
the inalterable victorious march of socialism. Thus, as soviet spokesmen have repeatedly pointed out, an intense struggle with the West, and in particular with the United States, is an inherent characteristic of detente. Brezhnev has stated in this regard that, despite "the successes in relaxing international tensions, a hard struggle against the enemies of peace, national and social liberation faces us." 156 The form that this struggle will take will be, as Soviet spokesman claim, in the field of economics, science, and the military. More importantly, this struggle will be increased in the realm of ideas, in an acute intensification of the ideological warfare between capitalism and socialism. "It must be stressed absolutely clearly," the Soviets tell us "that the improvements of relations between the Soviet Union and the United States in no way means an easing of the ideological struggle." 157 Rather than signalling an end to the ideological confrontation between East and West, detente will ensure that this struggle will become more intense and acute. As the Soviets have claimed, "it is necessary to be ready for a situation in which the weaker the positions of aggressive militarist circles, the greater the extent to which the ideological struggle will intensify and become an increasingly acute form of confrontation between the two social systems." 158 Hence, the Soviet Union has prepared for a fairly lengthy and fierce struggle with the United States, as outlined in the strategy of detente. As noted by Soviet commentators, "Marxist-Leninists have consistently associated peaceful coexistence with the prospect of further deepening and extending the inevitable development of the world revolutionary process." 159 By so doing, the Soviet Union, in the face of American opposition to this process, regards "peaceful coexistence as a form of confrontation between the two social 
systems." 160

Brezhnev has noted on a number of occasions that detente will involve a hard struggle on the part of the "forces of peace." Hence, in addressing the World Congress of Peace Forces, Brezhnev can claim:

...But I would like to stress most emphatically that neither peace nor detente will descend on the world in a manner of some divine blessing. Peace and detente can only be the result of persistent and tireless struggle by all peace forces - the states, political parties and tendencies, public bodies and individuals - against everything resisting detente, imperiling peace, and creating the danger of war. 161

Brezhnev has also claimed that this struggle will not be an easy one. In Brezhnev's words:

The struggle for the triumph of reason in international relations can hardly be an easy one. Every gain on the road to lasting peace comes about through struggle, through fierce clashes with the most reactionary circles of imperialism and their accomplices. 162

If the Soviet Union is to engage in this kind of confrontation with the United States, and if the Soviet-designed detente policy is the catalyst for this struggle, then it is logical for the U.S.S.R. to establish the "rules of the game" that will govern this conflict. The Soviet Union has, in fact, codified the rules governing detente, and has established clear limitations on what it sees as permissible action through this policy. To do so the U.S.S.R. has employed the one-sided perspective of Marxist-Leninist ideology and has arrived at conclusions that can be seen as a product of that ideology. The Soviet logic here is quite simple. The Soviet Union is the champion of peace, friendship, social progress, democracy, freedom, etc. The United States, on the other hand, is the promoter of war, aggression, exploitation of the masses, oppression, and the denial of freedom and national liberation, among others. The goals of detente are the elimination of war, aggression, 
exploitation, and national oppression, and the promotion of peace, social progress, and national liberation. Hence, by definition Soviet activities are adjudged as being consistent with the cause of detente, while American actions are quite obviously inappropriate if they are at odds with the objectives of the U.S.S.R.

Detente, from the Soviet view therefore, establishes unilateral restraints on the United States, while affording the Soviet Union freedom in pursuing actions that it assesses as being consistent with the cause of worldwide socialist gains. In analyzing the third Nixon-Brezhnev summit meeting held in Moscow, the U.S.S.R., immediately following the U.S. president's departure, noted that the policy of detente, as defined in the summit reinforced the Soviet quest to:

rebuff the intrigues of aggressive imperialist forces, to strengthen the socialist commonwealth, to ensure further growth in the U.S.S.R.' s economic and political might and an increase in the Soviet peoples' well-being, and to facilitate in every way the safeguarding of lasting peace on earth and the social progress of the peoples.163

The Soviet Union has applied these unilateral restrictions on American foreign policy in many areas of Soviet-American relations. Yet, it can be reasoned that it is in the realm of the national liberation struggle that the obvious nature of these limitations becomes most visible. The U.S.S.R. has shown that the national liberation struggle, and the Soviet support in any fashion for this struggle is quite legitimate. While detente is characterized by an absence of war and the existence of relaxation of tensions, it does not pertain to Western relations with the developing countries. As the Soviets have pointed out:

...there can be no peaceful coexistence between the oppressed and the oppressors, between the exploiters and the exploited, between the imperialist states and their colonies. There can be no peaceful coexistence in the 
context of the internal processes of the class and national liberation struggle in the capitalist countries

Thus, the United States is told that the restraints imposed upon it by detente eliminate the potential for suppressing the national liberation movement in any of the developing nations. More importantly, the Soviet Union is allowed to render any kind of support, including military, to strengthen revolutionary forces which are striving to assert national independence. As noted above, relaxation of tensions, peace, and friendship, the cornerstones of detente, do not apply to relations between the West and the developing world. However, as Brezhnev has often repeated, detente most definitely applies to Soviet support for the developing nations. As stated by Brezhnev:

Moreover, as we have done in past years, we shall pay great attention to promoting our relations with the nationalliberation forces, and with the new states of Asia and Africa that, having taken the path of freedom, are now endeavoring to consolidate their independence and promote their economic and social development. 165

Brezhnev can also claim that:

The entire course of postwar development has proved convincingly that colonialism and aggression, the policy of colonial tyranny and the policy of force, are essentially two sides of the same coin. There is therefore every justification for the fact that in the very name of your Congress (World Congress of Peace Forces) the struggle for peace is associated with the struggle for national liberation. 166

It is not surprising therefore, that the U.S.S.R. can apply this ideological logic to the question of war as a means of achieving objectives during an era of detente. The Soviet Union has consistently argued that the renunciation of war as a means for solving differences in the world is one of the primary goals of detente. "The Leninist policy of peaceful coexistence," we are told "embodies the irrefutable fact that wars as a means of achieving political aims are alien to the very nature of 
socialism." 167 Yet, in the Soviet view, all wars are not the same.

The Soviet Union has gone to great lengths to lecture the United States on the subject of wars during the new detente era, and to show that Soviet-inspired and/or Soviet supported wars of national liberation are quite legitimate and not contradictory to the principles of detente.

The Soviet lexicon therefore, provides the following definitions of just and unjust wars:

A war is just if it is a continuation of a policy of the defense of revolutionary gains, the freedom and independence of peoples and the cause of socialism and communism. A war is unjust and reactionary if it is a continuation of a policy aimed at suppressing revolutionary struggle, the freedom and independence of one people or another or the socialist gains of the working people, or at subjugating a particular country. 168

Brezhnev has claimed that such "unjust wars" take the form of

local wars. In Brezhnev's words:

We must not forget that wars will keep breaking out, people are still being killed, and cities, factories, villages, and objects of cultural value are being destroyed in various parts of the world. These are what politicians have become accustomed to calling "local wars," that is, wars confined to the relatively narrow boundries of some geographical region. Past experience shows that, as a rule, in modern conditions, these break out wherever and whenever the forces of imperialism and reaction attempt to put down liberation movements, or to obstruct the free and independent development of states that have opted for progressive internal development and the antiimperialist line in foreign policy.169

What the Soviet Union is saying, in this writer's view, is that detente affords the socialist world under the leadership of the U.S.S.R.

a carte blanche in regard to the conduct of its foreign policy. An analysis of the "objective" laws of Marxist-Leninist ideology will show, as the Soviets claim, that the justifiable nature of the actions pursued by the country advocating that ideology is true by definition. At the same time, the United States is reacting in an aggressive manner to the further dissemination of the socialist cause, thus rendering its 
foreign policy a hostile and inappropriate one. In this context, the United States can expect wars of national liberation to be waged against it or its supported governments, with the support of the U.S.S.R. Yet, the United States is told that any response on its part to these wars are reactionary in nature and will meet with a firm rebuff by the Soviet Union.

The U.S.S.R. has therefore, attempted to place one-sided restraints on the United States, while pursuing its own objectives in an unabated manner. The Soviet Union, during the latest detente has provided considerable support to the revolutionary causes of the developing nations, confronted the United States in Angola and the Middle East, and militarily intervened in Afghanistan. In a 17 these areas, among others, the Soviet Union has expressed shock and dismay at the critical American response. The Soviet Union has repeatedly asserted that these actions are not only beyond criticism from the perspective of detente, but are guaranteed components of that process.

\section{Soviet Objectives Within Detente}

The detente of Leonid Brezhnev differs in the areas outlined above from the detente of Lenin, Stalin, and Khrushchev by virtue of the means used to achieve the ultimate objective of detente, the worldwide victory of socialism. Lenin, it was shown, argued on the basis of his revolutionary philosophy that the Soviet Union could not coexist with the West for a long period of time and would therefore wage a life-and-death struggle with its ideological antithesis in the foreseeable future.

This total, cataclysmic war syndrome, as mentioned above, was revised by Khrushchev who transformed detente from a defensive maneuver to an offensive 
strategy. Brezhnev, in continuing the Khrushchev method of utilizing detente in the mode of a peacefur offensive, added the factors of strategic parity and a less bellicose image to his foreign policy, thus making it a more acceptable process for the capitalist-imperialist states.

It has been argued throughout this dissertation that Brezhnev, while altering the strategic basis of detente, has maintained detente as a policy that serves the cause of the worldwide victory of socialism. It remains to be shown how Brezhnev, through short-term objectives and strategies, hopes to use detente as a tool for achieving his and the Soviet Union's long-term objectives. Stated very simply, it can be argued that the spectrum of Soviet goais reads as follows:

1.) The final objective - the complete and final victory of socialism led by the Soviet Union.

2.) Strategic objective - the continued growth of the alignment of world forces in favor of socialism.

3.) Specific strategy - the alignment of "Third World" or developing nations into the socialist camp, through the anti-imperialist, pro-socialist national liberation movement.

These objectives are distinct, in this writer's view from the specific strategies or means used to achieve them, i.e., placing unilateral constraints upon the United States, eliminating the need for a thermonuclear war, exploiting antagonisms within the Western camp, maintaining strategic and conventional military parity, preciuding an anti-Soviet aliiance, utilizing economic assistance from the United States, etc. These tactical maneuvers might best be viewed as specific procedures detailing the generai blueprint for action as outlined in the objectives of the U.S.S.R. 
The final objective of detente has been dealt with in some detail above and need not be repeated here. However, the strategic objective, that of continuing the shift in the balance of world forces to the socialist side, deserves a careful analysis. It has been shown that the alignment of world forces in favor of socialism is, in the Soviet view, an accomplished fact. Indeed, in the Soviet view, the manifestation of this pro-socialist shift was the primary motivation for the West and specifically the United States to reassess its foreign policy and to agree to a detente with the Soviet Union. However, the Soviet Union is obviously not satisfied with maintaining the balance of world forces as it now exists, and is clearly intent upon further augmenting the ranks of the pro-socialist nations. The Soviet Union has repeatedly stressed that detente in no way signifies the preservation of the status quo in regard to political or social developments. As stated by Arbatov:

...in launching a broad peace offensive and a vigorous and consistent struggle for detente and for the triumph of the principles of peaceful coexistence in international relations, the Soviet Union and the other socialist countries did not assume, and indeed could not assume, a commitment to guarantee the social "status quo" in the world and to halt the processes of class and national liberation struggle engendered by the objective laws of historical development... 170

In the view of Suslov, the crises of capitalism have shown that "the absence of historical prospects for imperialism is becoming increasingly obvious at the present stage." 171 This, in conjunction with class struggles and antagonisms within "the entire world of capital,"

leads Suslov to conclude that the prospects for socialist expansion are improving. In Suslov's words: 
The working people's desire for unity is increasing in a number of countries, the positions of the Communist Parties and of all left wing forces have become considerably blows to imperialism. 172

It was mentioned earlier that the United States, in the words of Henry Kissinger, hoped to use detente as a means of displaying Western innovations and advancements to the public in the socialist world. The Soviet Union had apparent cause to be concerned, as the commodity-starved Soviet consumer might well find this array of Western goods to be quite attractive. Thus, Brezhnev continuously exhorted his and the East European bloc's communist parties to strengthen their ideological vigilance and cooperation. By so doing, Brezhnev argued that the increased contacts in detente could well serve the cause of socialist alignment. In Brezhnev's words:

We are convinced of the rightness of our path and of our Marxist-Leninist ideology, and we have no doubt that the expansion of contacts, which is natural in conditions of detente, exchanges of spiritual values and information and the development of ties between the publics of various countries will serve well to disseminate the truth about socialism and to win more and more new supporters to the side of the ideas of scientific communism. 173

Brezhnev, in advocating the policy of detente, has undoubtedly been mindful of conservative criticism within his own party. Brezhnev has taken the occasion of rebutting any anti-detente sentiment to reinforce the point that detente does not mean being "soft on capitalism," nor does it entail the maintenance of the status quo. In his address at the 25 th C.P.S.U. Congress, Brezhnev again asserted his belief that detente implies an inherent intensification of the ideological struggle with the West, and is designed, above all, to create favorable conditions for the further spread of socialism. Brezhnev then added: 
As for the far-left allegations that peaceful coexistence is the next thing to "helping capitalism" and "freezing the social and political status quo," our answer is this: Every revolution is first of all the logical result of the given society's internal development. What is more, life itself refutes the fabrications about "freezing." Suffice it to recall the great revolutionary changes that have taken place in the world in recent years.

That is how things stand with the question of the relationship between detente and the class struggle. Faithful to the revolutionary cause, we Soviet Communists are fighting and wi 11 continue to fight for peace - the supreme good for all peoples and an important condition for the progress of mankind in our

Much the same sentiment is echoed by Suslov who states:

We Communists have no illusions with respect to the antipopular nature and policies of imperialism or its ideology of anticommunism. The affirmation in international affairs of the principles of peaceful coexistence does not in the slightest signify a slackening of the class struggle on a worldwide scale or a "reconciliation" between socialism and capitalism. They are irreconcilable. It is a fact of reality that the class struggle in the international arena continues to be distinguished by great acerbity. Now, when the imperialists are becoming increasingly aware of the impossibility of overcoming socialism by force, this struggle is more and more often being carried over into the spheres of economics, politics and ideology. 175

The economic and political crises that the Soviet Union envisages in the West are, in the Soviet view, obvious manifestations of problems that make the capitalist system less attractive to the developing nations of the world. In conjunction with the already-existing worldwide shift toward socialism, these crises became major catalysts for an era of global transition from capitalism to socialism. "The numerous manifestations of instability in the economic and political system of imperialism are not the result of some accidental concurrence of circumstances," according to Kosygin. Rather, this is seen as "an objective developmenta] process in the epoch of the general transition from capitalism to socialism.

This "general transition" will certainly cause some probiems for the socia! ist world, as the imperialists will do everything in their power to halt this 
process. However, as Kosygin goes on to say:

But no matter how real the difficulties are that confront mankind on the path to peace, the international situation as a whole is now evolving in the interests of the peace-loving forces and in the interests of the peaceful future for mankind, not of the advocates of war. The alignment of forces between the two world systems is continuing to change in favor of
socialism. 177

It has been mentioned throughout the course of this report that detente has always provided the Soviet Union with a breathing spell, a respite in, or an absence of war. Peaceful relations with the United States, be it as an avoidance of war for Lenin, or an alternative to the Cold War for Brezhnev, have always, in the Soviet view, provided the best conditions for socialist proliferation and communist construction. Hence, it is not surprising that the U.S.S.R., through the latest detente, is confident that the alignment of world forces in favor of socialism is a cause that is best served by the policy of peaceful and cooperative inter-camp relations. An authoritative Pravda editorial can therefore, summarize the objectives of detente as follows:

Peaceful coexistence creates favorable conditions for the comprehensive development of the class struggle of the proletariat against the sway of capital and the struggle for national 1 iberation of oppressed and dependent peoples. To struggle for peaceful coexistence in our time means to struggle for the progress of mankind, since favorable opportunities for the solution of fundamental social problems are created in conditions of peace...178

The strategic objective of Soviet foreign policy, as defined in detente and explained by Soviet spokesmen, is quite clear. While avoiding a thermonuclear war, and utilizing American economic assistance, the U.S.S.R. is clearly attempting to further the process of shifting the balance of power in East-West relations in favor of the socialist commonwealth of nations. Such a course is consistent with the Soviet view of the final objective of detente, and is a reflection of a more 
gradual and incremental means by which to achieve long-term goals, specifically the complete victory of socialism on a worldwide basis. Yet, it can be argued that the U.S.S.R. cannot hope to achieve equal success in this regard in all areas of the world simultaneousiy. The existence of objective pre-conditions for socialist transformation, the development of mature communist parties, the level of capitalist entrenchment, the ability to wage wars of national liberation, and a host of other factors have made some geo-political areas more suitable than others for the shift to the socialist camp. The Soviet Union, in this regard, has looked upon the world of developing nations as the area most appropriate for the influx of socialist influence and the demise of American or Western control. Hence, it can be demonstrated that the specific strategy underlying the strategic objective of the further favorable alignment of world forces is the enhancement of the national liberation movement.

In speaking to the World Congress of Peace Forces, Brezhnev asserted:

For millions of people on our planet, there is still no peace, they are forced, arms in hand, to fight against imperialist aggressors and their accomplices and against the tyranny of invaders, for their own freedom and independence and for the elementary right to be masters in their own home. Peace partisans cannot fail to draw their own conclusions from this. 179

The conclusions to be drawn from Brezhnev's point of view are rather simple. The Soviet Union claims that the support for struggles against "invaders," and "imperialist aggressors" is an elemental factor in its foreign policy. Moreover, such support, even in the form of direct military assistance or the use of socialist military personnel (e.g. Cuban armed forces), is not contradictory to the spirit or intent 
of detente. In fact, such assistance is an inherent and unquestionable component of the process of Soviet-American detente. As the Soviet Union asks in rhetorical fashion:

As far as detente is concerned, isn't the struggle against racism and apartheid and the defense of and respect for the sovereignty of young independent countries a contribution to the easing of tension and to the creation on our planet of the necessary conditions for a peaceful, happy life for all peoples, large and small? 180

The U.S.S.R. can argue therefore, that the easing of tension in the international arena can best be accomplished by the proliferation of successful struggles for national liberation and independence by the developing countries. This process, replete with full Soviet support, must not appear as a form of Soviet hegemony, however. The U.S.S.R. is careful to show that the alignment of world forces, and not Soviet national interests, is served by the victories of national liberation struggles. In the words of Brezhnev:

The Soviet Union's attitude toward the complex processes in the developing countries is clear and definite. The Soviet Union does not interfere in the internal affairs of other countries and peoples. Respect for the sacred right to every people and every country to choose its own path of development is an immutable principle of our Leninist foreign policy. But we do not conceal our views. In the developing countries, as everywhere else, we are on the side of the forces of progress, democracy and national independence and regard them as our friends and comrades in struggle. 181

The national liberation movement and the alignment of newlyindependent developing countries in the socialist camp is, in the Soviet view, a major component of the Soviet desire to continue the pro-socialist shift in the balance of world power. "The Soviet Union is expanding its political ties with the developing countries," we are told, and is "supporting their endeavor to strengthen their independence, to advance along the path of sccial progress, to take an active part in world affairs, 
and to overcome vestiges of inequality in their foreign relations." 182 By so doing, the U.S.S.R. hopes to not only increase its camp of allies and decrease that of the United States, but to also make the process of detente and the pro-socialist alignment of world forces irreversible factors of international relations. Thus, the Soviet Union can argue as follows:

Acting shoulder to shoulder with world socialism, the developing countries can bring about genuine national liberation and the satisfaction of their legitimate interests and rights and can make a still weightier contribution to the struggle to reinforce the easing of tension and to make the positive changes in international relations irreversible. ${ }^{183}$

It is important to emphasize the point that successful national liberation wars and revolutions are contributing factors to the easing of international tension in the Soviet view. By eliminating the vestiges of imperialism, neo-colonialism, national oppression, and the like, the U.S.S.R. is serving the cause of peace and reducing international tensions. Since the agreed upon objective of detente is precisely this reduction of international tensions and the creation of world peace, the Soviets can logically argue that detente and national liberation struggles are synonymous objectives.

In supporting the cause of national liberation, the Soviet Union has focused its attention on the developing nations of Asia, Africa, and Latin America. However, it can be further shown that the U.S.S.R., during the latest detente, has placed special emphasis on the revolutionary process on the African continent. It is here that the U.S.S.R. has hoped to make significant progress in winning the support of the newly-independent former colonies. It is also on the African continent that the objective preconditions for a socialist transformation can be seen as being almost non-existent. Yet, the U.S.S.R. has demonstrated the remarkable 
ability, as taught by Lenin, to adapt and revise Marxist-Leninist revolutionary ideology so as to properly address any given circumstance. Hence, Soviet theoreticians have been able to devise a prescriptive format for the "special conditions" that characterize the revolutionaryliberation struggle in Africa. This special form for the African revolutionary process encompasses three basic stages:

1. The national liberation revolution. ("a broad anti-colonial, antiimperialist front is formed in which nearly all social strata of the population...participate to various extents").

2. The national-democratic revolution. ("the task of this stage is the struggle to consolidate political independence, achieve economic independence and advance along the path of social progress").

3. The socialist revolution. ("which presupposes the coming to power of the working people, headed by the working class"). ${ }^{184}$

The Soviet Union, in developing this three stage revolutionary process, has, in effect, admitted that the goal of socialist construction may well be a very distant objective for many former colonies and semicolonies. In the Soviet view, the difficulties encountered in underdeveloped countries "determine the need for a relatively long transitional period during which the socialist revolution develops, deepens and is crowned by the construction of a new society. "185 However, the longer the "transitional period" prior to the construction of a socialist society, the less attractive the model of a national liberation/socialist revolution might be to overly enthusiastic newly-freed colonies. Thus, the Soviet Union has continued the Leninist process of adapting ideology to the present environment, and allowed for a much shorter and more attractive revolutionary process. The U.S.S.R. can argue that during the 
detente era it is quite possible to fuse the revolutionary process

"into a single stream," thus creating a revolution with "an anticapitalist and socialist orientation." It can then be reasoned that:

Such a revolution, enormously accelerating the revolutionary process in the given country and shortening the intermediate stages of historical development, calls for the maximum acceleration of social development, which, with the support of other socialist states, can place on the agenda the construction of a socialist society. 186

The launching of an anti-imperialist and pro-socialist national liberation revolution, with the full support of the Soviet Union and the other socialist nations, is not a goal that is unattainable in the very near future. Rather, the Soviets argue, this objective can be realized almost immediately. Moreover, from the Soviet perspective, the goal of the construction of a "new (i.e. socialist) society" can also be accomplished in a relatively short period of time. It is important to note that the Soviets feel that it is detente that has created the necessary preconditions for this rapid process and which has made the socialist construction goals possible. After all, as the U.S.S.R. has often told us, detente creates the most favorable conditions for the construction of a new society. Soviet spokesmen can therefore, "consider the effect on Africa of detente, which has become ever more significant under the influence of the foreign policy of the Soviet Union and other socialist countries and progressive forces throughout the wor $1 d . " 187$ so as to leave no doubt as to the direct relationship of detente to the African national liberation movement, Soviet spokesmen can argue as follows:

What has happened and is happening in Africa is the development of the Portuguese colonial peoples' struggle for freedom and independence, new trends in relations with former mother countries and the like - all this has become possible as a direct result of detente, which has graphically demonstrated the narrowing of imperialism's 
opportunities. It is no longer so easy for imperialist

reactionaries to apply brute force to maintain their

supremacy in a given sector of the "third world." Then

too, public opinion in capitalist countries nowadays

reacts more sharply to all revivals of the earlier

"position of strength" policy. 188

The Soviet Union has therefore, made little, if any, attempt to conceal the fact that it will strive to woo the developing nations into the pro-socialist, or at a minimum the non-capitalist, camp. Furthermore, the policy of detente is seen as the major catalyst by which the national liberation struggle is waged. With the United States now unwilling or unable to muster a reasonable and meaningful response to Soviet activity in the third world, the U.S.S.R., under the aegis of detente, appears to be quite comfortable in pursuing its objectives there. The Soviet Union has also made no effort to hide the fact that it has realized a number of triumphs in the developing world during the most recent detente. The U.S.S.R. can both revel in the successes of socialist gains in the third world and use these triumphs as a form of appeal to those non-aligned nations which have not opted for Soviet support. Thus, in analyzing the 25th C.P.S.U. Congress, Soviet commentators can reason as follows:

The Congress declared very resolutely that the CPSU has supported and will continue to support peoples who are fighting for their freedom. The peoples of Vietnam, Chile, Laos, and Angola know this very well...

The 25th Congress reconfirmed the unconditional devotion of our Leninist Party to the fraternal alliance of workers of a 11 countries and to its consistent course aimed at uniting the ranks of the world Communist movement and at strengthening the solidarity of all anti-imperialist forces in the struggle for common aims... 189

Detente under Leonid Brezhnev has established the goals and objectives outlined above. As such, Brezhnev's detente appears, at first glance, to differ significantly from Lenin's detente. Yet, it can be reasoned that upon closer examination the differences appear to be less 
significant than the common threads that wind themselves through the detente policy of these two Soviet leaders. Both Brezhnev and Lenin have attempted to augment the ranks of the socialist camp and decrease that of the West, with the ultimate aim of vanquishing the latter.

Lenin hoped to realize this end with the aid of socialist revolutions in Europe, most notably in Germany. Brezhnev hopes to reach his goals with national liberation/socialist revolutions in the developing world. 


\section{FOOTNOTES: CHAPTER $V$}

1J.V. Stalin, "Political Report of the Central Committee to the Fourteenth Congress of the Communist Party of the Soviet Union," May, 1925 Leninism (New York: International Publishers, 1943),

\section{Ibid., p. 381.}

3 "Report by Litvinov, Vice-Commissar for Foreign Affairs to the Central Executive Committee," December 21, 1929, Jane Degras, ed., Soviet Documents on Foreign Policy, Vol. II, 1925-1932 (London: Oxford University Press, 1952), p. 409.

4 "Press Statement by Litvinov on His Appointment as Commissar for Foreign Affairs," July 25, 1930, Ibid., p. 449.

${ }^{5}$ Vojtech Mastny, Russia's Road to the Cold War: Diplomacy, Warfare, and the Politics of Communism, 1947-1945 (New York: Columbia University Press, 1979).

${ }^{6}$ It has been claimed, in fact, that Stalin laid considerable stress on the importance of theory. See Historicus, "Stalin on Revolution," Foreign Affairs, Vol. 27, No. 2 (January, 1949), p. 175.

${ }^{7}$ This argument is presented in a comprehensive and we11-documented fashion in Elliot R. Goodman, The Soviet Design for a World State (New York: Columbia University Press, 1960).

${ }^{8}$ Pravda, March 10, 1953, p. 1. Translated in The Current Digest of the Soviet Press, Vol. V., No. 7 (March 28, 1953), p. 8.

9Leonid Brezhnev, "Address on American Television," June 24, 1973, Peace, Detente, and Soviet-American Relations (New York: Harcourt Brace Jovanovich, 1979), p. 21.

10L.I. Brezhnev, Pravda, February 25, 1976, p. 2.

${ }^{11}$ Ibid., p. 6.

${ }^{12}$ See Brezhnev's report to the 24 th C.P.S.U. Congress, March 30 , 1971 as reported in Pravda, March 31, 1971, pp. 2-10.

13L.I. Brezhnev, Pravda, May 2, 1971, p. 1.

14L.I. Brezhnev, Pravda, May 15, 1971, p. 1. 
${ }^{15}$ L.I. Brezhnev, Pravda, June 16, 1971, p. 3.

16 Pravda, August 3, 1971, p. 1.

17L.I. Brezhnev, Pravda, February 25, 1976, p. 3.

18 Leonid Brezhnev, "Speech on Receiving the International Lenin Peace Prize," July 11, 1973, Soviet-American Relations, pp. 34, 41.

19 Leonid Brezhnev, "From Speech at White House Dinner," June 18, 1973, Soviet-American Relations, p. 13.

${ }^{20}$ A Representative sample of viewpoints on this subject may be found in: Jerry F. Hough, "The Man and the System," Problems of Communism, Vol., XXV, (March-Apri1, 1976), pp. 1-17, William E. Odom, "Who Controls Whom in Moscow," Foreign Policy, No. 19 (Summer, 1975), pp. 109-123., and Grey Hodnett, "Succession Contingencies in the Soviet Union, Probiems of Communism, Vol. XXIV, (March-Apri1, 1975), pp. 1-21.

${ }^{21}$ Leonid Brezhnev, "Speech at the World Congress of Peace Forces," October 26, 1973, Soviet-American Relations, p. 52.

22 Ibid., p. 60.

23Leonid Brezhnev, "To My American Reader," Ibid., p. 5.

${ }^{24}$ Leonid Brezhnev, "Address on American Television," June 24, 1973, Ibid., p. 27.

25L.I. Brezhnev, Pravda, September 7, 1973, p. 1.

${ }^{26}$ Leonid Brezhnev, "From Speech to the Electors in the Bauman District of Moscow," June 14, 1974, Ibid., p. 67.

27 Leonid Brezhnev, "From Speech Upon Presenting the Gold Star Meda 1 to the Hero City of Tula," January 18, 1977, Ibid., p. 147.

${ }^{28}$ M.A. Suslov, Pravda, December 15, 1972, p. 4.

${ }^{29}$ G. Arbatov, "On Soviet-American Relations," Kommunist, No. 3 , February, 1973, p. 103.

30L.I. Brezhnev, Pravda, February 26, 1976, p. 6.

31 Ibid.

32L.I. Brezhnev, Pravda, October 6, 1976, p. 1.

${ }^{33}$ G. Arbatov, "On Soviet-American Relations," p. 101.

34 Ibid., p. 103.

${ }^{35}$ Leonid Brezhnev, "Speech at the World Congress of Peace Forces," October 26, 1973, Soviet-American Relations, p. 46. 
36L.I. Brezhnev, Pravda, September 23, 1973, p. 1.

37 Ibid.

${ }^{38}$ L.I. Brezhnev, Pravda, June 30, 1976, p. 2.

${ }^{39}$ Leonid Brezhnev, "From Address on West German Television," May 21, 1973, Soviet-American Relations, p. 10.

40 Leonid Brezhnev, "Speech on Receiving the International Lenin Peace Prize," Ju1y 11, 1973, Soviet-American Relations, pp. 37-38.

${ }^{41}$ Yu V. Andropov, Pravda, Apri1 23, 1976, p. 2.

42 Ibid.

43 Ibid.

${ }^{44}$ Ibid.

45

Ibid.

46 Ibid. (parenthesis added)

47L.I. Brezhnev, Pravda, February 25, 1976, p. 6.

${ }^{48}$ L. I. Brezhnev, Pravda, October 26, 1976, p. 3.

${ }^{49}$ Ibid.

50 Leonid Brezhnev, "Speech at the World Congress of Peace Forces," October 26, 1973, Soviet-American Relations, p. 65.

${ }^{51}$ Leonid Brezhnev, "From Speech to the Electors in the Bauman District of Moscow," June 13, 1975, Ibid., p. 88.

52 M.A. Sus 1ov, Pravda, June 21, 1972, p. 1.

53 M.A. Sus 1ov, Pravda, June 21, 1972, p. 1.

${ }^{54}$ L. I. Brezhnev, Pravda, February 25, 1976, p. 2.

${ }^{55}$ Ibid., pp. 2-5.

${ }^{56}$ Ibid. , p. 5.

${ }^{57}$ G. Arbatov, "On Soviet-American Relations," p. 105.

${ }^{58}$ G. Arbatov, Pravda, Ju1y 22, 1973, p. 4.

${ }^{59}$ L.I. Brezhnev, Pravda, June 30, 1976, p. 1.

60 Ibid. 
61 L.I. Brezhnev, Pravda, February 25, 1976, p. 2.

62 Ibid., p. 5.

63 It has been suggested that the Russian drive for a European security conference dates back to an initiative by Malenkov in 1954.

See Coral Be11, The Diplomacy of Detente (New York: St. Martin's Press, 1977), pp. 109-170.

${ }^{64}$ L.I. Brezhnev, Pravda, June 30,1976, p. 1.

65 Ibid.

${ }^{66}$ L.I. Brezhnev, Pravda, February 25, 1976, p. 5.

67 Ibid.

${ }^{68}$ Be11, The Diplomacy of Detente, p. 114.

${ }^{69}$ L.I. Brezhnev, Pravda, June 30, 1976, p. 1.

70L. I. Brezhnev, Pravda, September 25, 1973, p. 1.

${ }^{71}$ G. Arbatov, "On Soviet-American Relations," p. 106.

72 M.A. Suslov, Pravda, June 21, 1972, p. 1.

$73_{\text {Ibid. , p. } 105 .}$

74 Ibje.

${ }^{75}$ L.I. Brezhnev, Pravda, October 26, 1976, p. 2.

${ }^{76}$ Leonid Brezhnev, "Speech on Receiving the International Lenin Peace Prize," July 11, 1973, Soviet-American Relations, p. 37.

77 Leonid Brezhnev, "To My American Reader," Ibid., p. 4.

78 Leonid Brezhnev, "From Speech Upon Presenting the Gold Star Medal to the Hero City of Tu1a," January 18, 1977, p. 149.

${ }^{79}$ A.A. Grechko, Pravda, June 5, 1974, p. 2.

${ }^{80}$ G. Arbatov, Pravda, July 22, 1973, p. 4.

${ }^{81}$ G. Arbatov, "On Soviet-American Relations," p. 106.

82 Leonid Brezhnev, "Speech at the World Congress of Peace Forces," October 26, 1973, Soviet-American Relations, p. 43.

83 M.A. Suslov, Izvestia, August 24, 1972, p. 2.

${ }^{84}$ G. Arbatov, Pravda, Ju1y 22, 1974, p. 4. 
${ }^{85}$ Ibid.

${ }^{86}$ Leonid Brezhnev, "From May Day Speech in Red Square," May 1, 1973, Soviet-American Relations, p. 7.

${ }^{87}$ G. Arbatov, "On Soviet-American Relations," p. 105.

${ }^{88}$ L.I. Brezhnev, Krasnaia Zvezda, March 5, 1971 , p. 1. 89 Ibid.

90 L.I. Brezhnev, Pravda, October 26, 1976, p. 3.

${ }^{91}$ L.I. Brezhnev, Pravda, October 6, 1976, p. 1.

92 Ibid.

93L.I. Brezhnev, Pravda, February 25, 1976, p. 7.

${ }^{94} G$. Arbatov, "On Soviet-American Relations," p. 106.

${ }^{95}$ Colonel I. Sidelnikov, Krasnaia Zvezda, August 14, 1973, p. 2.

96 Leonid Brezhnev, "Speech at the World Congress of Peace Forces," October 26, 1973, Soviet-American Relations, p. 46.

97 Leonid Brezhnev, "To My American Reader," Soviet-American Relations, p. 3.

98 L.I. Brezhnev, Pravda, October 26, 1976, p. 3.

${ }^{99}$ A.A. Grechko, Krasnaia Zvezda, May 30, 1975, p. 1.

100L.I. Brezhnev, Pravda, October 27, 1973, p. 1.

${ }^{101}$ G. Arbatov, Pravda, Ju1y 22, 1973, p. 5.

102 Ibid.

${ }^{103}$ Colonel I. Sidelnikov, Krasnaia Zvezda, August 14, 1973, p. 3.

104 Leonid Brezhnev, "From Speech Upon Presenting the Goid Star Meda to the Hero City of Tula," January 18, 1977, Soviet-American Relations, P. 149.

705 Leonid Brezhnev, "Speech at the World Congress of Peace Forces," October 26, 1973, Soviet-American Relations, p. 58.

${ }^{106}$ Editorial, Pravda, June 4, 1975, p. 4.

107 A.A. Grechko, Krasnaia Zvezda, May 30, 1975, p. 1.

${ }^{108}$ Yu. V. Andropov, Pravda, Apri1 23, 1976, p. 2.

${ }^{109}$ Ibid. 

110 Arthur M. Schlesinger, Jr., "Detente: An American Perspective,"
in Detente in Historical Perspective, Friedlander (New York: Cyrco Press, 1975)

111 This statement was made during a panel discussion at the first CUNY Conference on History and Politics, and reported in Ibid., p. 100.

112 George Schwab, "Appeasement and Detente: Some Reflections," Ibid., p. 144 .

113 Ibid.

${ }^{114}$ L. I. Brezhnev, Pravda, March 31, 1976, p. 3.

115

Ibid.

116 Ibid.

117

Ibid., p. 5 .

${ }^{118}$ L.I. Brezhnev, Pravda, February 25, 1976, p. 3.

119 Leonid Brezhnev, "From Speech at White House Dinner,"

June 18, 1973, Soviet-American Relations, p. 14.

120 Leonid Brezhnev, "Speech at the World Congress of Peace Forces," October 26, 1973, Soviet-American Relations, p. 55.

121 L.I. Brezhnev, Pravda, June 30, 1976, p. 1.

122 Ibid.

123 Ibid.

${ }^{124}$ L.I. Brezhnev, Pravda, February 25, 1976, p. 6.

125 Ibid.

126 D. Kraminov, Pravda, May 30, 1973, p. 4.

127 N. Patolichev, Pravda, December 27, 1974, p. 4.

128 Leonid Brezhnev, "Address on American Television," June 24, 1973, Soviet-American Relations, p. 24.

129 Leonid Brezhnev, "From Speech to the Electors in the Bauman District of Moscow," June 14, 1974, Ibid., p. 72.

130 Leonid Brezhnev, "Speech at Kremlin Dinner during the Second Moscow Session of the U.S.-USSR Trade and Economic Counci1," October 15, 1974, Ibid., p. 81 .

${ }^{131}$ Ye. Shershnev, Pravda, June 13, 1973, p. 4. 
132 Ibid.

133L.I. Brezhnev, Pravda, June 30, 1976, p. 2.

${ }^{134}$ L.I. Brezhnev, Pravda, February 25, 1976, p. 6.

135 Ibid.

${ }^{136}$ I. Melnikov, Pravda, December 4, 1974, p. 5.

137 Ibid.

138 Ibid.

${ }^{139} \mathrm{G}$. Arbatov, "On Soviet-American Relations," p. 104.

140 Ibid.

141 Leonid Brezhnev, "Speech at the World Congress of Peace Forces," October 26, 1973, Soviet-American Relations, p. 62.

${ }^{142}$ L.I. Brezhnev, Pravda, October 12, 1974, p. 1.

143 Ibid.

144 K. Brutents, Pravda, August 30,1973, p. 4.

145 Ibid.

146 Leonid Brezhnev, "To My American Reader," Soviet-American Relations, p. 3.

147 Leonid Brezhnev, "From May Day Speech in Red Square," May 1, 1973, Ibid., p. 7.

${ }^{148}$ M.A. Sus7ov, Pravda, December 15, 1972, p. 4.

${ }^{149}$ L.I. Brezhnev, Pravda, February 25, 1976, p. 6.

150 Ibid.

${ }^{151}$ A. Sovetov, "The Leninist Policy of Peace and the Future of Mankind," International Affairs (Moscow), No. 7, Ju7y, 1972, p. 4.

152 Ibid.

153Leonid Brezhnev, "To My American Reader," Soviet-American Relations, p. 3.

${ }^{154}$ Leonid Brezhnev, "Speech on Receiving the International Lenin Peace Prize," Ju7y 17, 1973, Ibid., p. 33.

${ }^{155}$ L.I. Brezhnev, Pravda, August 16, 1973, p. 2. 
156

157 B. Gafurov, Izvestia, August 31, 1982, p. 1.

158 V. Korionov, Pravda, July 13, 1972, p. 2.

${ }^{159}$ A. Sovetov, "Peaceful Coexistence - A Real Factor in International Relations," International Affairs (Moscow), No. 9, September, 1972, p. 10.

160 Ibid.

${ }^{161}$ Leonid Brezhnev, "Speech at the World Congress of Peace Forces," October 26, 1973, Soviet-American Relations, p. 57.

162 Leonid Brezhnev, "From Speech to the Electors in the Bauman District of Moscow," June 14, 1974, Ibid., pp. 72-73.

${ }^{163}$ Pravda, Ju1y 6, 1974, p. 1.

${ }^{164}$ A. Sovetov, "A Real Factor," p. 11.

165 Leonid Brezhnev, "Speech on Receiving the International Lenin Peace Prize," July 11, 1973, Soviet-American Relations, p. 38.

${ }^{166}$ Leonid Brezhnev, "Speech at the World Congress of Peace Forces," October 26, 1973, Ibid., pp. 47-48.

${ }^{167}$ Colonel V. Khalipov, Krasnaia Zvezda, July 21,1972, p. 1.

${ }^{168}$ Colonel I. Sidelnikov, Krasnaia Zvezda, August 14, 1973, p. 3.

${ }^{169}$ Leonid Brezhnev, "Speech at the World Congress of Peace Forces," October 26, 1973, Soviet-American Relations, pp. 57-58.

$170_{G}$. Arbatov, Izvestia, September 4, 1975, p. 3.

171 M.A. Suslov, Pravda, October 23, 1974

172 Ibid.

173L.I. Brezhnev, Pravda, August 16, 1973, p. 2.

174 Ibid.

${ }^{175}$ M.A. Sus 1ov, Pravda, December 15, 1972, p. 4.

${ }^{176}$ A.N. Kosygin, Pravda, November 3, 1974, p. 2.

177 Ibid.

${ }^{178}$ F. Ryzhenko, Pravda, August 22, 1973, p. 4.

${ }^{179}$ L.I. Brezhnev, Pravda, October 27, 1973, p. 1. 
180 Izvestià, January 7,1976 , p. 1.

181

${ }^{182}$ K. Brutents, Pravda, August 30,1973, p. 5.

183 Ibid.

184 P.I. Manchkha, "Communists, Revolutionary Democrats and the Noncapitalist Path of Development in African Countries, "Voprosy

Istori i KPSS, No. 10 (October, 1976), pp. 57-69, transiated in The Current Digest of the Soviet Press, Vo1. XXVII, No. 51 (January 21,1976 ),

$185 \mathrm{~V}$. Lyusinov, "On Forms of Revolutionary Transition to Socialism in Developing Countries, "Mirovaya Ekomika i Mezdunarodniye Otnoshenia, No. 2 (February, 1973) pp. 16-26, translated in The Current Digest of the Soviet Press, Vol. XXV, No. 21 (June 20, 1973), p. 7.

186

Ibid.

${ }^{187}$ V. Kudryavtsev, Izvestia, May 25, 1974, p. 4.

188 Ibid.

${ }^{189}$ v. Zagladin, Pravda, April 20, 1976, p. 3. 


\section{H A P T E R V I \\ CONCLUSIONS}

The introductory chapter of this dissertation presented three major hypotheses. Taken together, these hypotheses addressed what this writer felt were the most widely misunderstood aspects of the policy of detente. Moreover, these hypotheses provide a concise capsule summarization of what this writer views as the essence of detente. It is important therefore, to examine these hypotheses here in summary fashion in light of the evidence presented within the body of this report.

The first hypothesis posited the belief that detente is a political strategy that was designed by the U.S.S.R., that has its theoretical foundation in Marxist-Leninist revolutionary ideology, and is governed by the dictates of that ideology. It was shown here that detente was not mutually developed by the Soviet Union and the United States. Rather, detente was and is a political strategy that was conceived by the U.S.S.R. as a means by which to properly manage the temporary coexistence of capitalism-imperialism and socialism. Having initiated the policy of detente, the Soviet Union attempted for a number of years to have the United States accept the Soviet philosophy of detente as the cnly alternative to American decision makers. It was only recently, in the Soviet view, that the United States realistically assessed the alignment of world forces, the growing might of the Soviet Union, the existence of strategic parity, and the bankruptcy of pursuing an anti-Soviet course of action. Thus, the United States, according to the Soviet perception, has finally been forced to accept 
detente, as defined by the Soviet Union, as a political necessity. Detente may have been transformed from a defensive tactic to an offensive strategy and finally to an aggressive policy with unilateral constraints placed upon the United States. Yet, as was shown, it was the Soviet Union that initiated these revisions, and it was the Soviet Union that has continualiy defined the scope and purpose of detente.

In addition, it was demonstrated that detente was created on the basis of revolutionary Marxist-Leninist ideology. While attempting to achieve the ultimate objective of communist ideology the Soviet Union realized that a policy of peace with the West was an urgent need. Detente was presented here as a means by which the U.S.S.R. could best realize the objective of transforming the world in the communist order and of achieving the ultimate and total defeat of the capitalistimperialist system.

Two distinct schools of thought on this subject matter were analyzed. The first school presented the general belief that ideology had been replaced by concerns of national interest, balance of power, and power politics as the major determining factors of Soviet foreign policy. Characterized by an "end of ideology" posture, this school looked upon ideology as a secondary concern, and as a manipulative or cosmetic aspect of Soviet foreign policy. However, it was shown that ideology formed the nucleus of the Soviet policy of detente in its earliest formation in 1918. While many of the tactical components of detente have been altered or revised in the ensuing sixty-two years, the central core of the policy has not been changed. An unswerving comitment to the ultimate goal of Soviet ideology, the final defeat of the West, has remained as the major focal point of the Soviet 
policy of detente.

When analyzed amidst the background of short-term Soviet objectives, the detente policy may very well appear to be a non-ideological strategy. However, it was argued that it was difficult to separate shortterm goals of Soviet foreign policy from its much broader long-term objectives. It was also reasoned that gradual and incremental shifts in the balance of power in favor of the U.S.S.R. are but small pieces in a much larger Soviet design. The Soviet Union has repeatedly informed us that the goal of the construction of a new society can best be accomplished in conditions of peace. Detente, in the Soviet view, was created as the best means to achieve that peace and the objective of socialist proliferation and communist construction.

The second hypothes is stated that detente was a political strategy developed by V.I. Lenin in 1918. Thus, detente in 1972 or 1980 can be seen as the present variation of a policy that was initiated by the U.S.S.R. Shortly after the Bolshevik seizure of power in Soviet Russia. It has become fashionable to apply the term detente to SovietAmerican relations from 1972 to 1980, with the normalization of those countries' relations under the leadership of Richard Nixon and Leonid Brezhnev. Yet, it was argued that detente as practiced by Brezhnev is a policy that is both a descendant and continuation of a strategy that was conceived by Lenin.

Lenin, confronted with an array of foreign and domestic difficulties, realized in March of 1918 that he could not guarantee his political survival without a large-scale consolidation of strength. Furthermore, Lenin knew all too well that he could not pursue the objective of defeating the capitalist-imperialist system until such time 
as he was strong enough to confront his enemies. Thus, Lenin required a breathing spell, a respite in war, by which he could prepare himself for the final confrontation with the West. Detente was created by Lenin as the policy that would provide this respite.

It was reasoned that in designing detente, Lenin addressed eight major needs of Soviet Russia. Detente would provide the necessary time, in conditions of peace, that would allow for the internal consolidation of strength by the new Soviet regime. Detente afforded the Soviet Union the opportunity to survive as an "oasis" in a capitalist-imperialist world until such time as other nations could join the socialist ranks. Detente gave Lenin the time to focus on the inordinate East-West military imbalance and to implement the corrective action necessary to achieve military parity. Detente underscored the objective necessity of waging a total East-West war and provided the means by which Lenin could best prepare for this final inter-camp conflict. Detente afforded Lenin the opportunity of preparing for the inevitable alliance of anti-socialist forces and the eventual onslaught against the U.S.S.R. Detente provided the forum by which Lenin could expand East-West economic ties and secure the much needed influx of Western economic assistance that was vital to the ravaged Soviet economy. Detente gave Lenin the chance to exploit any and all antagonisms within the capitalist-imperialist camp, thus precluding any anti-Soviet alliance among his enemies. Most importantly, detente provided Lenin with the best means by which he could achieve the goal of gaining the worldwide victory of socialism.

The policy of detente that was created in 1918 and revitalized in 1920-1921 did not die with the passing of Lenin. Stalin, in gaining complete hegemony over Soviet politics during his lifetime, continued 
the policy of detente that was bequeathed to him. While making subtle shifts in the overall detente formula, Stalin adhered to the basic core of detente as designed by Lenin. In fact, Stalin was able to strengthen the internal and international position of the U.S.S.R. and therefore, strengthen the policy of detente.

Nikita Khrushchev continued the policy of detente as updated by his predecessor. However, Khrushchev realized the need to alter the policy and to transform detente from a defensive tactic to an offensive strategy. Hence, Khrushchev revised many of the original detente components of Lenin and restructured the policy in the mold of a more gradual process that did not necessitate the inevitability of a final East-West confrontation.

Brezhnev maintained the basis of detente that he inherited upon his assumption of power in the Kremlin. Yet, Brezhnev realized the need to reduce the obvious threat presented to the West during the cold War years and to re-design the detente process in the form of a more appealing political strategy. However, Brezhnev was able to add a very aggressive strain to detente and make the policy, in reality, a far greater threat to American interests.

Thus, the third major hypothesis presented the view that detente, conceived and implemented by the U.S.S.R., has posed and will continue to pose serious threats to the interests of the United States. In fact, detente, as perceived by the Soviet Union could by definition accrue unilateral advantages to the cause of world socialism. It was shown that detente was created by the Soviet Union and was a direct by-product of a revolutionary ideology that has avowed goals and objectives that are inimical to those of the United States. Thus, in theory, the Soviet 
policy of detente poses an inherent threat to American interests.

In accepting the terms of detente as established by the U.S.S.R. the United States has not only given credibility to this Soviet strategy but has also increased the threatening character of the policy. By condoning Soviet-styled detente, as the U.S. did from 1972 to 1976 , the American government, as was argued, afforded the U.S.S.R. the opportunity to conduct U.S.-Soviet relations in a manner that gave Moscow much to gain and little, if anything, to lose.

It was shown that the United States has reassessed the detente policy recently and has demonstrated an unwillingness to adhere to the principles of detente as established by the Kremlin regime. However, the Soviet Union, far from seeing the demise of Soviet-American detente, is doing all in its power to make the process irreversible. The soviet Union has repeatedly informed us in the West that the causes for the American dissatisfaction with detente are not only not contradictory to the spirit of detente, but are necessary and inevitable components of that policy.

The U.S.S.R. has made no attempt to conceal the fact that detente established the best conditions for the further dissemination of socialist influence and the construction of communism. In short, detente and the American willingness to accept detente will, in the Soviet view, provide the catalyst by which the Soviet Union will realize its uitimate communist objectives. Hence, it is not surprising that the U.S.S.R. can assert that detente will signal a drastic intensification of the East-West ideological struggle and that detente will sharpen and reinforce the class antagonisms with the West. According to the Soviet Union, detente ras been forced upon the United States by the 
American realization of its weakening position in the world and the growing might of the Soviet Union. While the reality of the alignment of world forces in favor of socialism forced the United States to accept detente, it will be detente, in the Soviet view, that will be the fulcrum for the further favorable alignment of world forces.

The Soviet Union has claimed that detente has as its ultimate objective the total collapse of the West and the complete worldwide victory of socialism. In this view, detente is an irreversible policy that will not condone the status quo posture, sustainment of the present balance of power, or any attempted convergence with the United States. In addition, detente, from Moscow's perspective, allows for the support of the U.S.S.R. for wars of national liberation, and violent anti-Western national revolutions. At the same time, detente is not applicable to American relations with the newly developing former colonies and will not allow for any American reaction to national liberation endeavors. Detente does not permit the buildup of "aggressive" military forces by the United States, but at the same time, necessitates continued increases in Soviet military power.

Stated very simply the Soviet theory of detente would place unilateral restraints upon the United States and seriously hinder any American action that would threaten Soviet ideological goals. Simultaneously, detente, from the Soviet perspective, would permit the U.S.S.R. to conduct its foreign policy with almost no constraints as it is designed with the objectives of securing "peace" and "freedom" for al1 peoples. It was also argued that the Soviet theory of detente has also been translated into practice. Having achieved the long sought after military parity with the United States, the U.S.S.R. has used the threat 
of a thermonuclear confrontation between the two superpowers as a factor that would seriously hinder any direct American response to hostile Soviet actions. Thus, it can be reasoned that the theory and practice of detente has not only failed to diminish aggressive and anti-Western Soviet activity but has allowed for its more active pursuit.

It was stated earlier that the history of Soviet-American relations is, in fact, the history of Soviet-American detente. It can also be argued that this history has been quite successful for the Soviet Union and has been less than favorable for the United States. Prior to the Bolshevik revolution in 1917 the United States was not confronted with any communist adversary. When the first communist government came to power it initiated detente as a desperation policy that would buy the necessary time to ensure its survival. Amidst the background of detente the Soviet Union was able not only to ensure its own preservation but to watch over the spread of communist control to many other nations. In time, detente lost its necessary defensive and protective character and became the means by which the Soviet Union could further proliferate socialist/communist influence. In 1981 the United States is confronted with a number of communist adversaries as the alignment of world forces is indeed in favor of the socialist world. The historical progression from 1918 to 1981 that was inspired by detente can logically continue as long as detente remains the dominant East-West and Soviet-American activity. The non-communist world is the minority socioeconomic system in 1981. It can be argued that the continued adherence to detente, as defined by the U.S.S.R., by the United States will continue to foster the demise of the non-communist world of nations. 


\section{SELECTED BIBLIOGRAPHY}

American Association for the Advancement of Slavic Studies, The Current Digest of the Soviet Press. V, XXV, XXVIII, XXXII. Columbus, Ohio: American Association for the Advancement of Slavic Studies.

Arbatov, G. "On-Soviet-American Relations," Kommunist 3 (February,
1973), 101-106. Aspaturian, Vernon $V$. Process and Power in Soviet Foreign Policy.
Boston: Little

Bauer, Raymond A.; Inkeles, Alex.; and Kluckhohn, Clyde. How the Soviet System Works. New York: Vintage Books, 1956.

Bel1, Coral. The Diplomacy of Detente. The Kissinger Era. New York: St. Martin's Press, 1977.

Be11, Daniel. "Ten Theories in Search of Reality: The Prediction of Soviet Behavior." Process and Power in Soviet Foreign Policy. Edited by Vernon $V$. Aspaturian. Boston: Little Brown and Co., 1971.

- The End of Ideology: On the Exhaustion of Political Ideas in the 50's. New York: ColTier Books, 1961.

Brzezinski, Zbigniew. "How the Cold War Was Played." Foreign Affairs. LI (October, 1972), 207-209.

- Ideology and Power in Soviet Politics. New York: Praeger, 1962.

- The Soviet B1oc: Unity and Conflict. Cambridge: Harvard University Press, 1967.

Brezhnev, Leonid. Peace, Detente, and Soviet-American Relations. New York: Harcourt Brace Jovanovich, 1979.

Carro11, E. Malcolm. Soviet Communism and Western Opinion 1979-1927. Chapel Hi11: University of North Carolina Press, 1965.

Conquest, Robert. Power and Policy in the U.S.S.R.: The Struggle for Stalin's Succession. New York: Harper and Row, 1967.

Cumming, C.K., and Pettit, Walter W. Russian-American Relations, March, 1917-March 1920: Documents and Papers. New York: Harcourt, Brace, and Howe, 1920. 
Daniels, Robert V. "Doctrine and Foreign Policy." The Conduct of Soviet Foreign Policy. Edited by Erik P. Hoffman and Frederick J. Fleron, Jr. Chicago: Aldine-Atherton, 1971.

Degras, Jane, ed. Soviet Documents on Foreign Policy, 2 vols. London: Oxford University Press, 1951. Vol. I: 1917-1924, and Vol. II:
1925-1932.

Dinerstein, Herbert S. Fifty Years of Soviet Foreign Policy. Baltimore:

The Johns Hopkins Press, 1968.

Fainsod, Merle. How Russia is Ruled. Cambridge: Harvard University
Press, 1967 .

Galbraith, John Kenneth. The New Industrial State. Boston: Houghton Mifflin, 1967.

Goodman, Elliot R. The Soviet Design for a World State. New York: Columbia University Press, 1960.

Graves, William S. America's Siberian Adventure. New York: Peter Smith, 1941.

Griffith, William E. The Sino-Soviet Rift. Cambridge: M.I.T. Press, 1964.

Historicus. "Stalin on Revolution." Foreign Affairs. Vol. 27, No. 2 (January, 1949): 175-214.

Hodnett, Grey. "Succession Contingencies in the Soviet Union." Problems of Communism. XXIV (March-Apri1, 1975): 1-21.

Hough, Jerry F. "The Man and the System." Problems of Communism. XXV (March-Apri1, 1976): 1-17.

"The Soviet System: Petrification or Pluralism," Problems of Communism. XXI (March-Apri1, 1972): 25-45.

Hunt, R.N. Carew. "The Importance of Doctrine." The Conduct of Soviet Foreign Policy. Edited by Erik P. Hoffman and Frederick J. Fleron, Jr. Chicago: Aldine-Atherton, 1971.

Inkeles, Alex. Social Change in Soviet Russia. New York: Simon and Schuster, 1971.

Kanet, Roger E., Bahry, Donna. "Soviet Policy in East Europe." Current History. LXIX (October, 1975): 126-128-154.

Kennan, George F. Russia and the West Under Lenin and Stalin. New York: New American Library, 1960.

- Soviet-American Relations, 1917-1920, Vol. II. Princeton: Princeton University Press, 1958. 
Kohier, Foy D. and Harvey, Mose L., eds. The Soviet Union: Yesterday,
Today, Tomorrow. Miami: University of Miami Press, 1975 .

Kohler, Foy D. Understanding the Russians: A Citizen's Primer.
New York: Harper and Row, 1970.

Lane, David. Politics and Society in the U.S.S.R. New York: Random
House,

Lenin, V.I. Collected Works. Vols. XXII, XXIII, XXVI, XXVII, XXVIII, XXXIII, XLII, XLIV. Moscow: Progress Publishers, 1964.

- Selected Works. Vols. I, II, III, IV, V, VI, VII, VIII, IX, X, XI. New York: International Publishers, 1943.

Lowenthal, Richard. "Unreason and Revolution." Comparative Politics; Notes and Readings. Edited by Roy C. McCridis and Bernard E. Brown. Homewood, Illinois: The Dorsey Press, 1972.

Manning, Bayless. "Goals, Ideology, and Foreign Policy." Foreign Affairs. LIV (January, 1976): 276-284.

Mastny, Vojtech. Russia's Road to the Cold War: Diplomacy, Warfare, and the Politics of Communism, 1947-1945. New York: Columbia University Press, 1979.

Meyer, Alfred $G$. The Soviet Political System: An Interpretation. New York: Random House, 1965.

Mitchell, R. Judson. "Continuity and Change in Soviet Ideology." Current History. LXIX (October, 1975): 137-141, 147.

Moore, Barrington, Jr. Soviet Politics - The Dilemma of Power.

Cambridge: Harvard University Press, 1951.

Odom, William E. "Who Controls Whom in Moscow." Foreign Policy. 19 (Summer, 1975): 109-123.

Possony, Stefan T. The Lenin Reader. Chicago: Henry Regnery Co., 1966.

Rakowska-Harmstone, Teresa. "Socialist Internationalism and Eastern Europe." Survey. XXII (Winter, 1976): 38-54.

Rapoport, Anatol. The Big Two: Soviet American Perceptions of Foreign Policy. New York: Pegasus, 1977.

Schapiro, Leonard. The Government and Politics of the Soviet Union. New York: Vintage Books, 1965.

Sharp, Samuel L. "National Interest: Key to Soviet Politics." The Conduct of Soviet Foreign Policy. Edited by Erik P. Hoffman and Frederic J. Fleron, Jr. Chicago: Aldine-Atherton, 1971. 
Shub, David. Lenin: A Biography. Baltimore: Penguin Books, 1967.

Sovetov, A. "The Leninist Policy of Peace and the Future of Mankind." International Affairs. (Moscow) 7 (July, 1972): 2-6.

"Peaceful Coexistence - A Real Factor in International Relations." International Affairs. (Moscow) 9 (September, 1972): 8-12.

Stalin, J.V. Leninism. New York: International Publishers, 1943. Strakhovsky, Leonid. Intervention at Archangel. Princeton: Princeton
University Press, 1944.

- The Origins of American Intervention in North Russia, 1918. "The Strangled Cry of Solzhenitsyn." National Review. (August 29, 1975):
934.

Tatu, Michel. Power in the Kremlin from Khrushchev to Kosygin. New York: The Viking Press, 1968.

Ulam, Adam B. Expansion and Coexistence. The History of Soviet Foreign Policy, 1917-1967. New York: Praeger Publishers, 1968.

"Soviet Ideology and Soviet Foreign Policy." The Conduct of Soviet Foreign Policy. Edited by Eric P. Hoffman and Frederic J. Fleron, Jr. Chicago: Aldine-Atherton, 1971.

U.S. Congress. House Committee on Foreign Affairs. Detente. Hearings before the subcommittee on Europe of the Committee on Foreign Affairs, House of Representatives, 93rd Cong., 2nd Sess., 1974.

U.S. Congress. U.S. Foreign Policy for the 1970's: Shaping a Durable Peace. A Report to the Congress by Richard Nixon, President of the United States. Washington, D.C.: Government Printing Office, 1973.

U.S. Department of Commerce, National Technical Information Service. Foreign Broadcast Information Service. Daily Report, Soviet Union, Vol. III.

U.S. Department of State. Bulletin. Washington, D.C.: Government Printing Office, VoTs. LXX, LXXII, XLLIII, LXXIV, LXXV, LXXVI.

U.S. Department of State. United States Foreign Policy, 1972: A Report of the Secretary of State. Washington, D.C.: Government Printing Office, April, 1973.

Vernadsky, George. A History of Russia. New York: Praeger Publishers, 1968. 
Wolfe, Bertram D. "Communist Ideology and Soviet Foreign Policy." Foreign Affairs. XLI (October, 1962): 152-170.

Zagoria, Donald S. The Sino-Soviet Conflict. Princeton: Princeton University Press, 1961.

Zimmerman, William. Soviet Perspectives on International Relations, 1956-1967. Princeton: Princeton University Press, 1969. 

6.

1) WhWWh

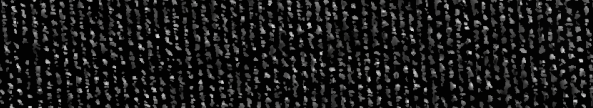

Whithith

How

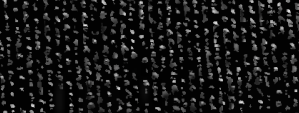

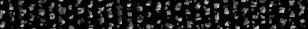

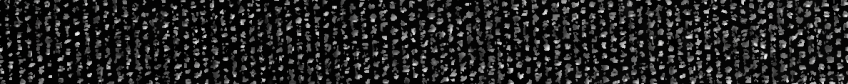

H.

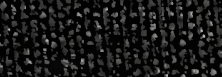

(1) 